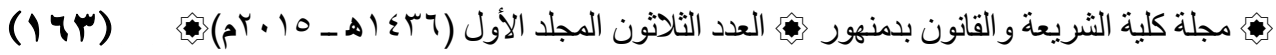

المسئولية عن فمل الحيوان

"دراسة مقارنة بالفقه الإسلامي"

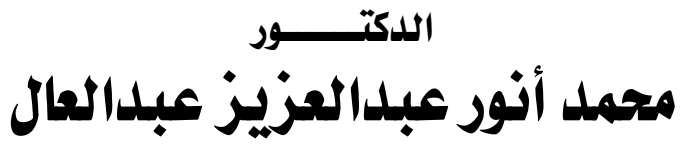

$$
\begin{aligned}
& \text { أستاذ القانوة المتني المساعت } \\
& \text { بكلية الشريعة والقانوة بائسيوها } \\
& \text { جامهـة الأزهــــ }
\end{aligned}
$$




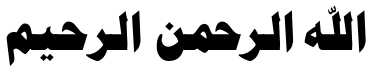

\section{الاقدمة :}

الحمد لله رب العالمين ، والصلاة والسلام على أشرف المرسلين ، سيدنا محمد ـ · وبعد ...

فإن موضوع " المسئولية عن فعل الحيوان " من الموضوعات الهامة التي تحتاج

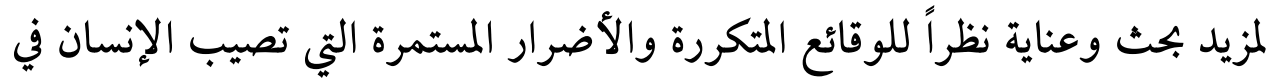
نفسه أو ماله جراء فعل الحيوان ، فقد يهمل أو يقصر صاحب الحب الحيوان في

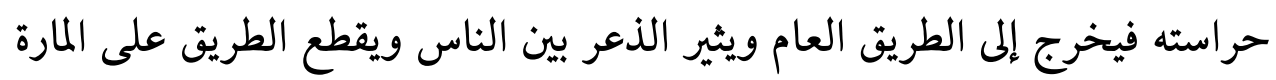

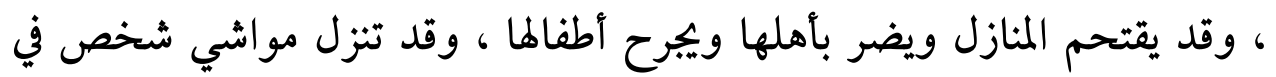

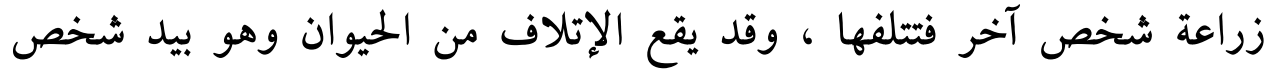
كر اكبه أو قائده .

لكل هذا كانت الحاجة ماسة لتحديد الشخص المسئول عن فعل الحيوان ،

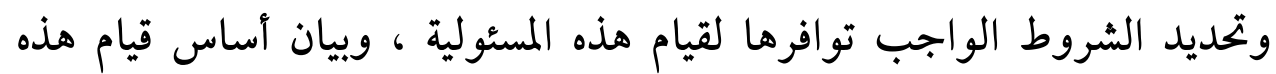
المسئولية ووسيلة دفعها . ويلاحظ : أن التعبير بالمسئولية في فقه القانون يقابله في الفقه الإسلامي

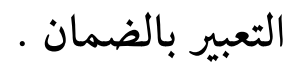

ووفقاً لما سبق ذكره ، فقد خططت لأن يكون بجثي في هذا الموضوع مكوناً من 


$$
\text { تمهيد وأربعة مباحث وخاتمة . }
$$

التمهيد : في المقصود بالمسئولية والحيوان .

المبحث الأول : تحديد المسئول عن فعل الحيوان . وفيه ثلاثة مطالب :

المطلب الأول : تحديد المسئول عن فعل الحيوان في القانون المدني .

المطلب الثاني : تحديد الضامن لفعل الحيوان في الفقه الإسلامي •

المطلب الثالث : الموازنة بين القانون المدني والفقه الإسلامي في تحديد

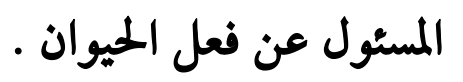

المبحث الثاني : شروط قيام المسئولية عن فعل الحيوان ـ . وفيه ثلاثة مطالب :

المطلب الأول : شروط قيام المسئولية عن فعل الحيوان في القانون المدني.

المطلب الثاني : شروط ضمان فعل الحيوان في الفقه الإسلامي .

المطلب الثالث : الموازنة بين القانون المدني والفقه الإسلامي في شروط

$$
\text { قيام المسئولية عن فعل الحيوان . }
$$

المبحث الثالث : أساس قيام المسئولية عن فعل الحيوان ـ وفيه ثلاثة مطالب:

المطلب الأول : أساس قيام المسئولية عن فعل الحيوان في القانون المدني .

المطلب الثاني : أساس ضمان فعل الحيوان في الفقه الإسلامي . 


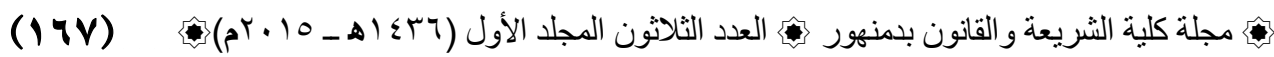

المطلب الثالث : الموازنة بين القانون المدني والفقه الإسلامي في أساس قيام

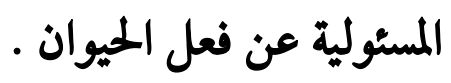

المبحث الرابع : وسيلة دفع المسئولية عن فعل الحيوان .وفيه ثلاثة مطالب :

المطلب الأول : وسيلة دفع المستولية عن فعل الحيوان في القانون المدني.

المطلب الثاني : وسيلة نفي الضمان عن فعل الحيوان في الفقه

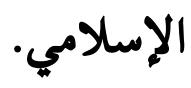

المطلب الثالث : الموازنة بين القانون المدني والفقه الإسلامي في وسيلة

$$
\begin{aligned}
& \text { دفع المسئولية عن فعل الحيوان . } \\
& \text { الخاتمة : وقد أبرزت فيها نتائج البحث . }
\end{aligned}
$$

وبعد : فالله أسأل أن يلهمني الصواب فيما أقول ، وأن يغفر زللي حين أخطاً ،

$$
\text { فهو سبحانه سميع بجيب الدعاء. }
$$

وصلى الله على سيدنا محمد و على آله وصمبه . 


\section{التمهيد}

\section{المقصود بالمسئولية والحيوان}

\section{المتصود بالمسئولية :}

المسئولية في اللغة من سأل يسأل سؤالا وسآلة ومسألة فهو مسئول والاسم

$$
\text { مسئولية . }
$$

جاء في لسان العرب (1) : ( سأل يسأل سؤالا وسآلة ومسألة... وقوله تعالى :

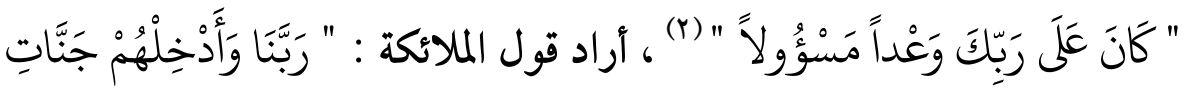

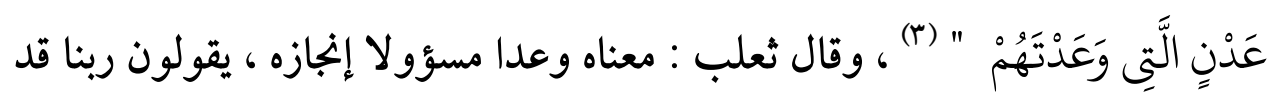

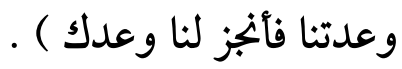

ويراد بالمسئولية في اصطلاح الفقهاء : " إلزام الـشخص بـضمان الـضرر الواقع

بالغير نتيجة لتصرف قام به " (๕)

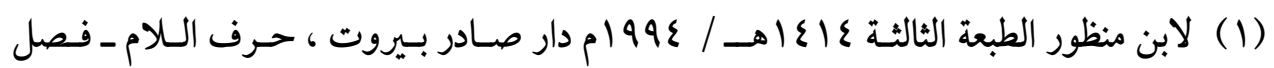

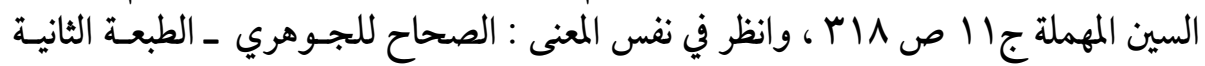

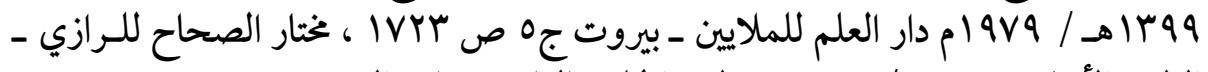

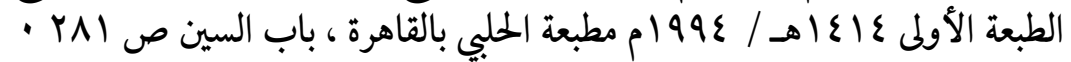

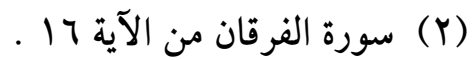

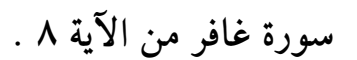

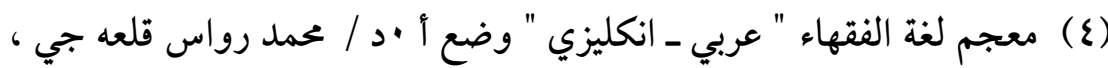

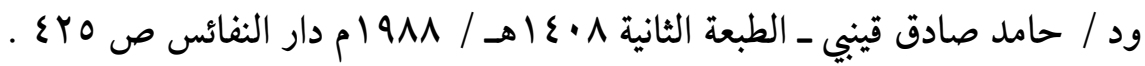




\section{والمسئولية في القانون المدني تنقسم إلى قسمين : (1) \\ مسئولية مدنية عقدية ، ومستولية مدنية تقصيرية .}

فالمسئولية العقدية هي تلك التي تترتب على حدوث الضرر الناشئ عن

الإخلال بالتزام عقدي ، ويلتزم المدين بتعويض الضرر الناتج من إخلاله بتنفيذ

التزاماته العقدية على الوجه المتفق عليه فيه ، ومثال ذلك التزام المقاول بتعويض الضرر الناتج عن التأخر في إقامة البناء الذي تعهد ببنائه عن الميعاد المتفق عليه . أما المسئولية التقصيرية فهي تلك التي تنشأ عن الإخلال بالتزام قانوني هو الالتزام بعدم الإضرار بالغير ، دون أن يكون هناك ثمة علاقة عقدية بين المسئول عن الفعل الضار والمضرور ، ومثال ذلك قائد السيارة الذي يصيب أحد

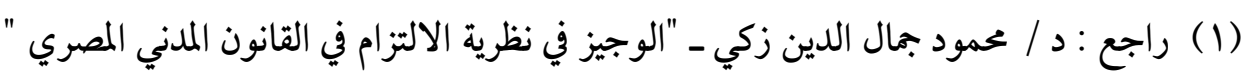

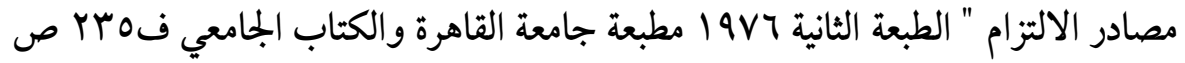

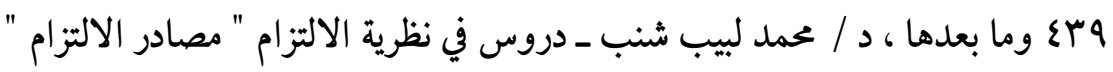

$$
\text { المصادر غير الإرادية }
$$

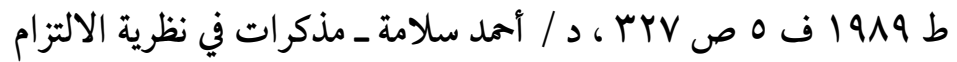

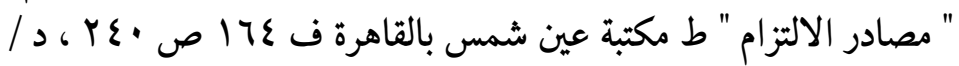

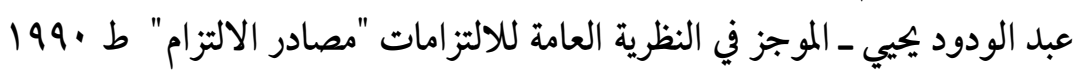

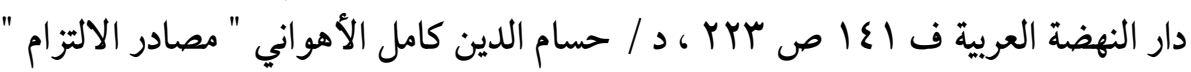

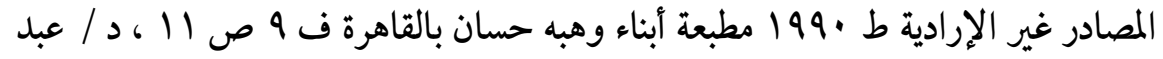

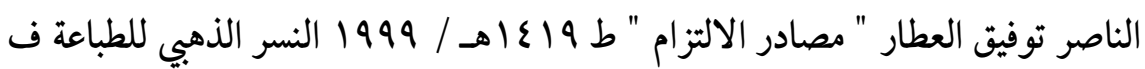

د / محمد علي عمران ـ المدخل لدراسة القانون " مصادر الالتزام وأحكامه وإثباته "

$$
\text { ط 19AV ص الما وما بعدها }
$$


المارة ويسبب له جروحاً ، فإنه يكون مسئولاً مسئولية تقصيرية لا تعاقدية ،

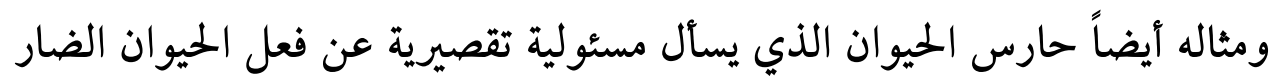

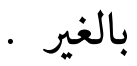
وعلى ذلك فالمسئولية المدنية تكون عقدية إذا كان الضرر الذي أصاب

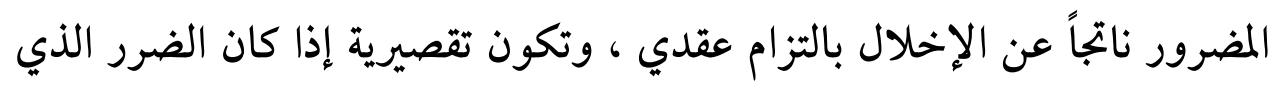

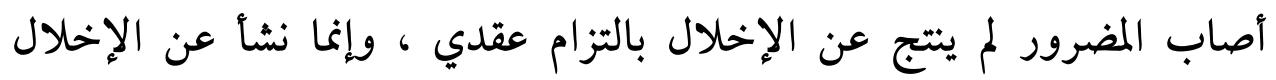

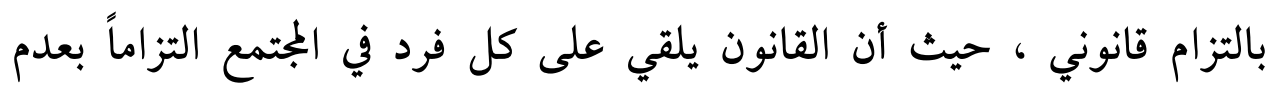

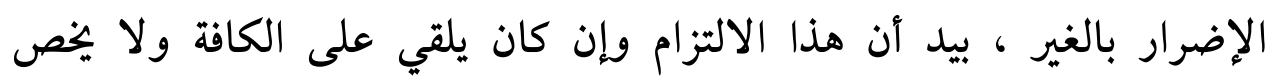

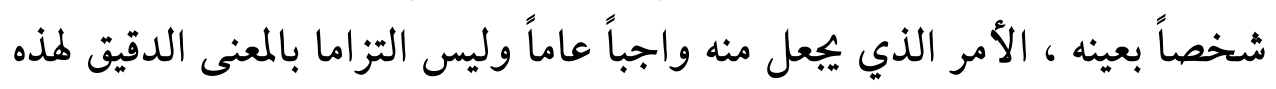

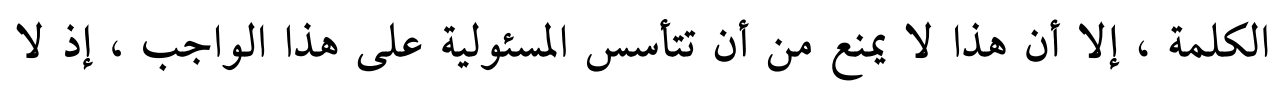

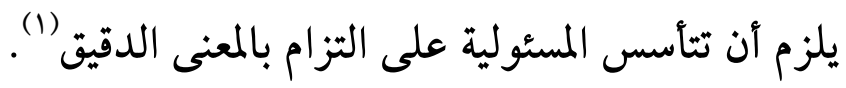

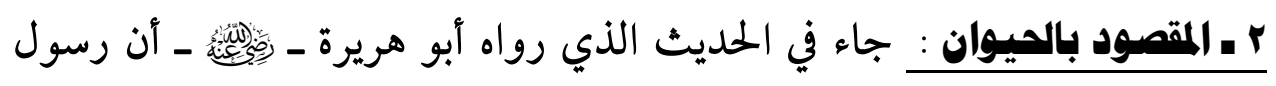

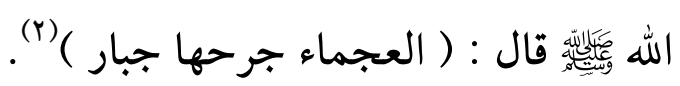
والمراد " بالعجماء " كل حيوان غير الآدمي ، وسميت البهيمة بالعجماء لأنها

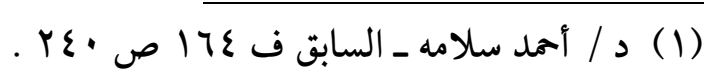

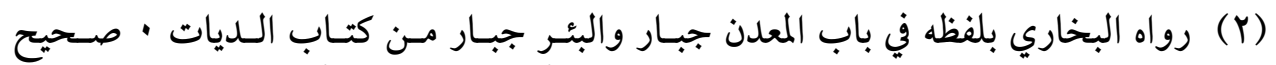

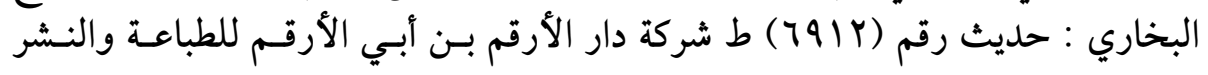

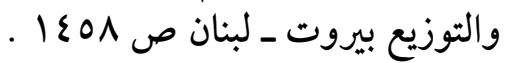

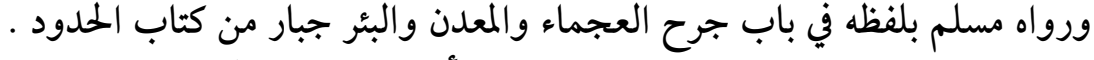

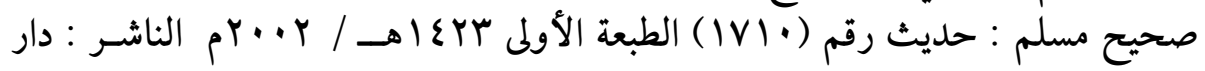

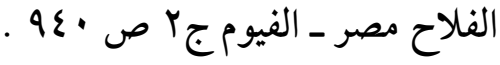




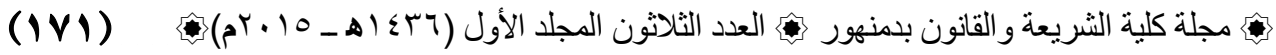

لا تتكلم (1)، ومن ثم فكلمة " العجماء " تشمل جميع الحيوانات الحية ، مفترسة أم غير مفترسة (r).

وفي القانون المدني المصري الحالي، نجد أن المادة IVT تنص على أن:

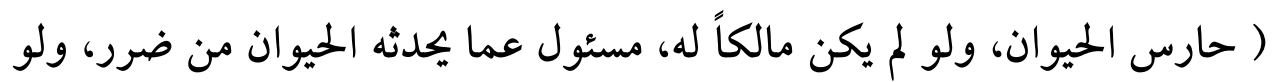

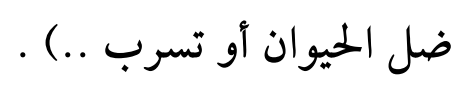

ويتبين من هذا النص أنه لم يحدد الحيوانات التي يسأل الشخص عنها،

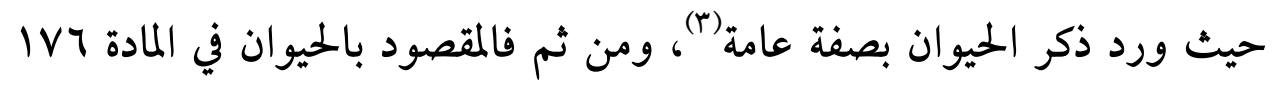

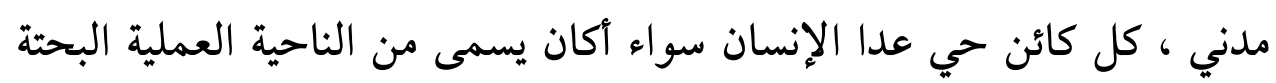

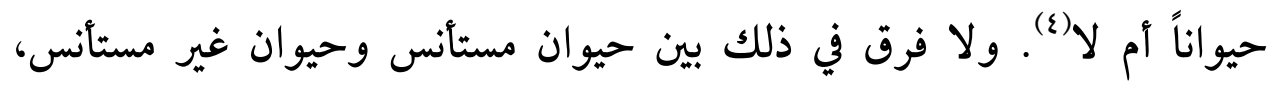

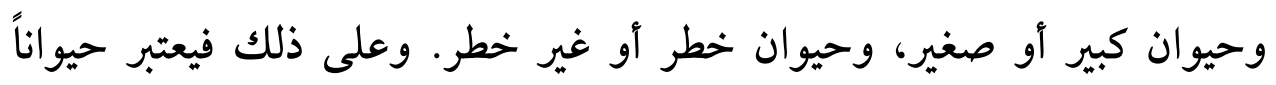

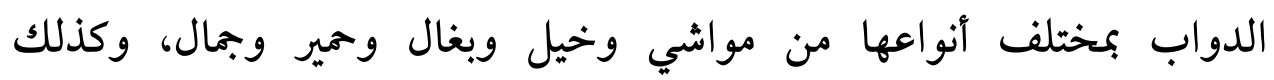

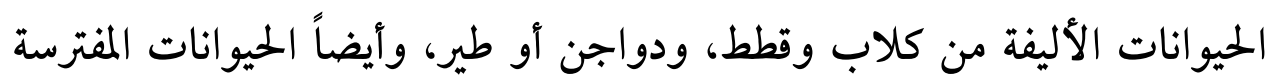
من أسود ونمور وفيلة ونحوها.

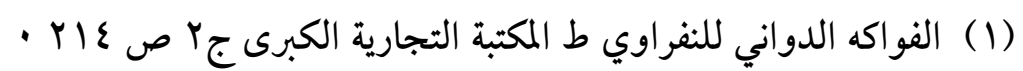

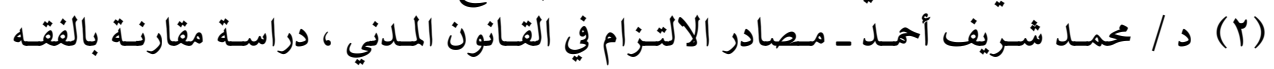

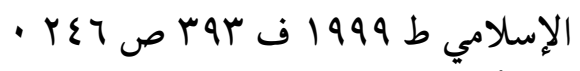

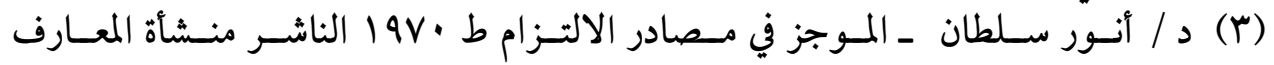

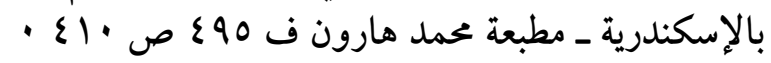

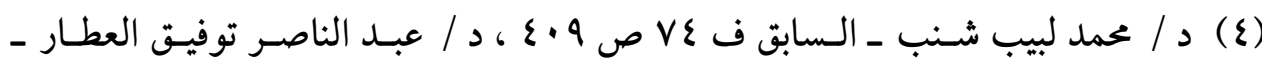

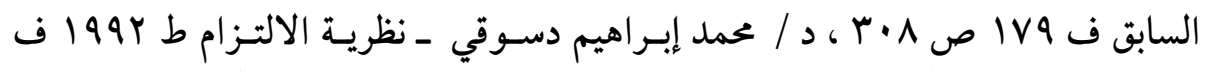

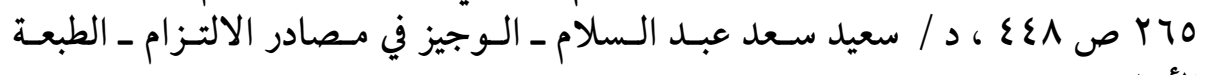

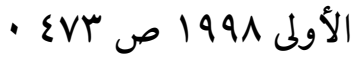


ولا فرق أيضاً بين ما إذا كان الحيوان منقولاً أم عقاراً بالتخصيص

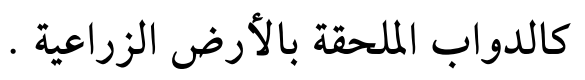

ولا عبرة باختلاف الغرض من اقتناء الحيوان ، فلا فرق بين ما إذا كان الاقتناء للركوب ، أو للإفادة من دره أو نسله أو لحمه ، أو كان للزينة أو أو معداً

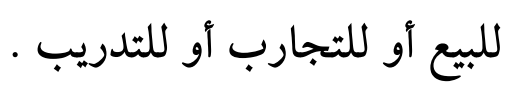

ولكن يشترط أن يكون الحيوان حياً ومملوكاً لأحد الأشخاص ، فجثة

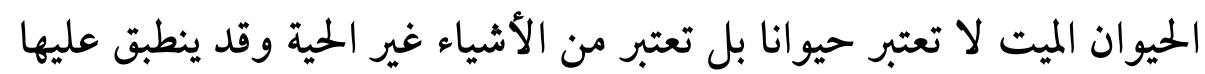

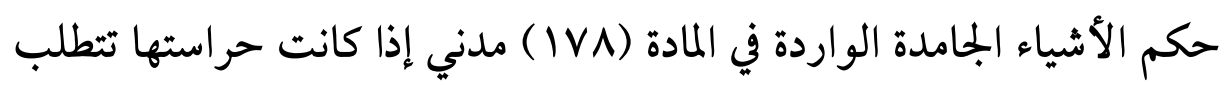

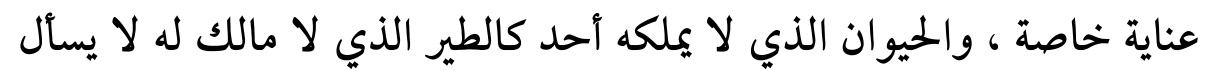

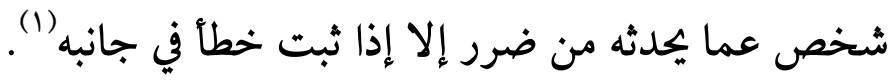

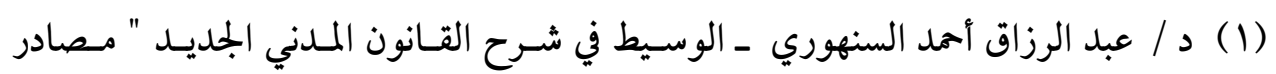

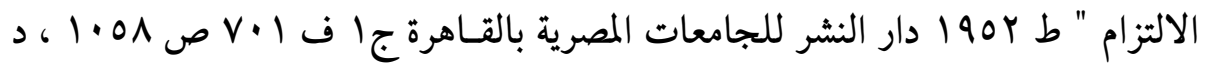

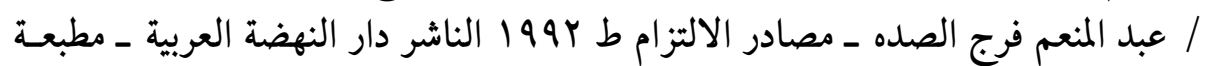

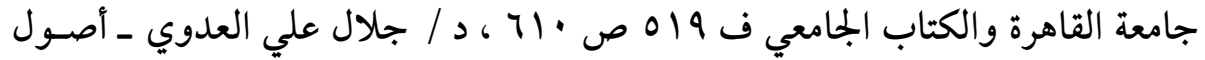

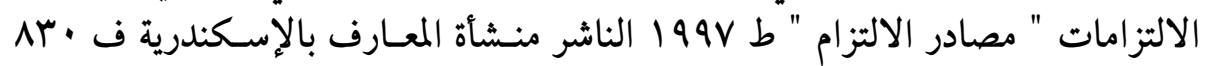

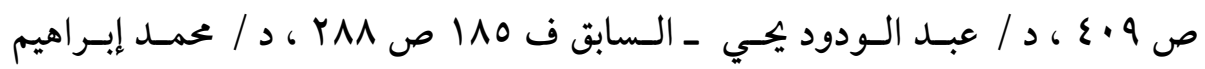




\section{المبحث الأول}

\section{تحليل المسئول عن فعل الحيوان}

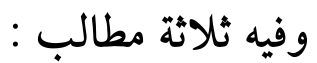

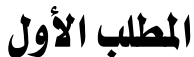

\section{تحديل المسئول عن فعل الحيوان في القانون الملدني}

نصت المادة IVT مدني على أن : ( حارس الحيوان ، ولو لم يكن مالكاً

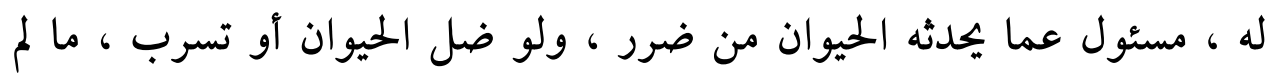

يثبت الحارس أن وقوع الحادث كان بسبب أجنبي لا يد له فيه )(').

وبالنظر في هذا النص يتضح أن المسئول عن الأضرار الناشئة عن

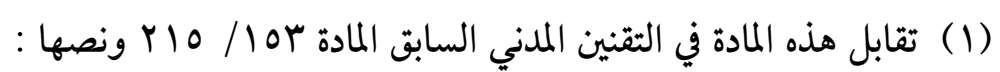

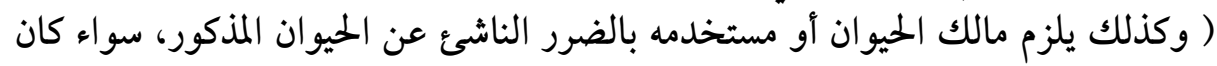

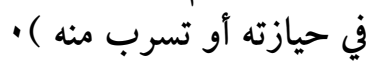

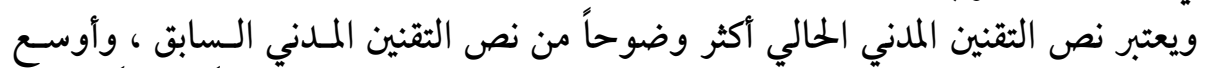

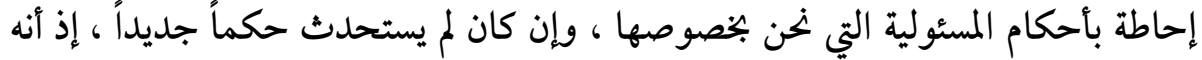

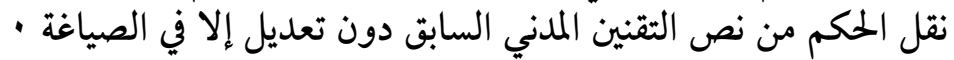

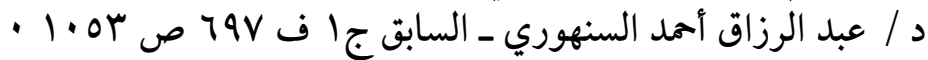

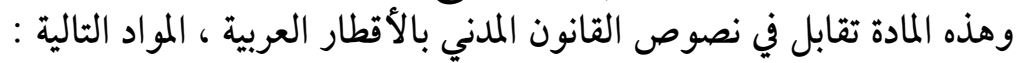

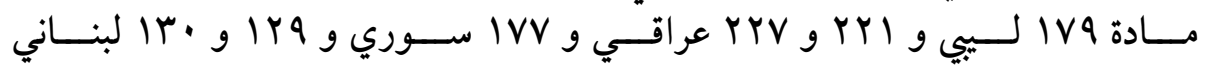

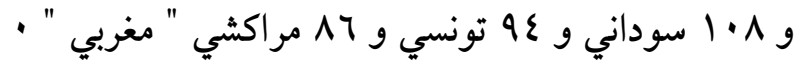

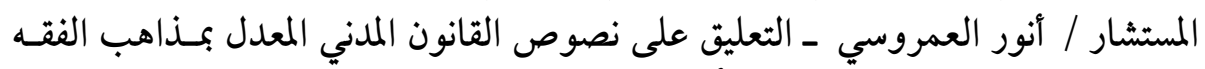

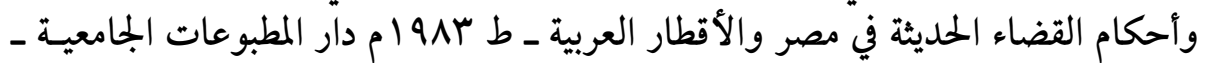

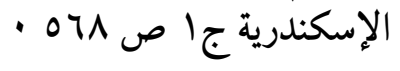


الحيوانات هو حارس الحيوان ، فإذا لم يكن للحيوان حارس وقت حصول

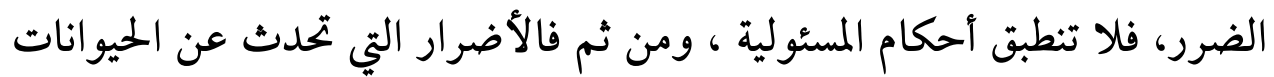

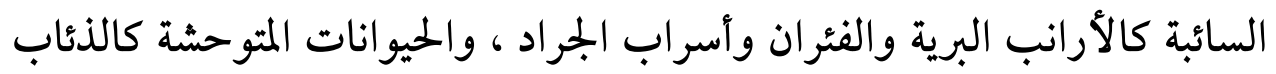

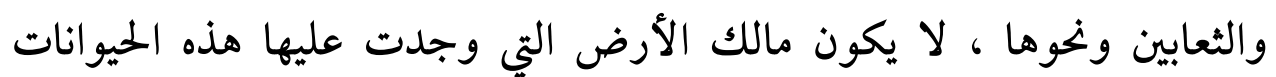

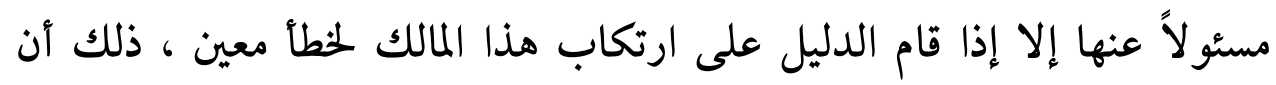

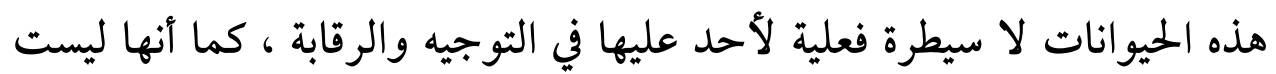

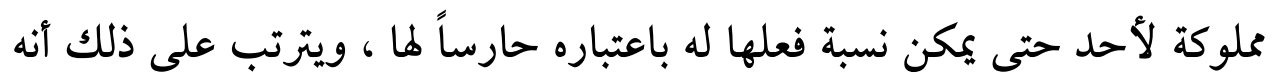

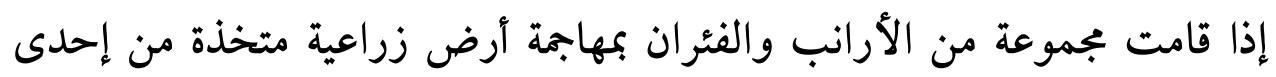

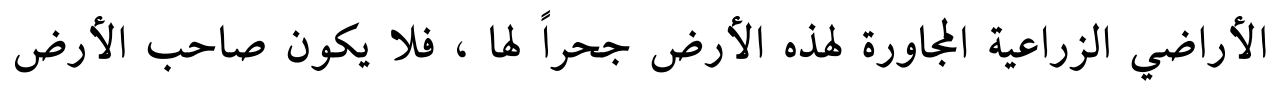

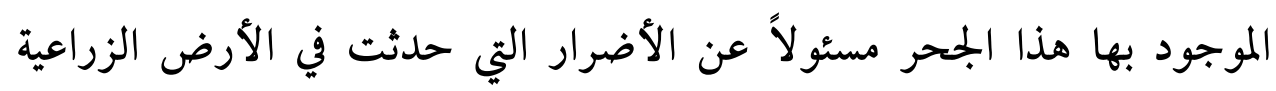

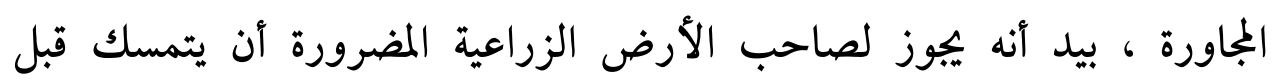

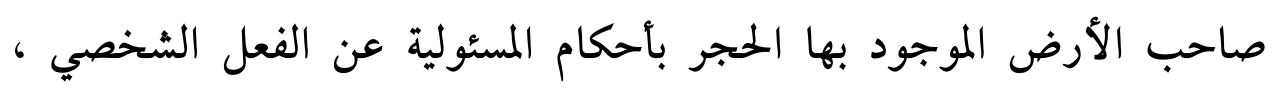

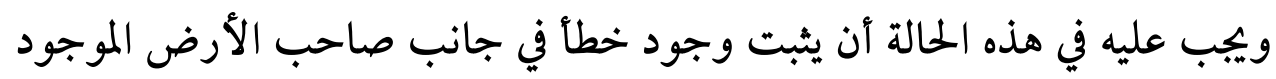

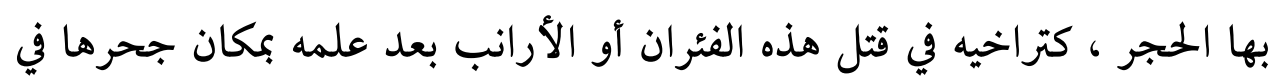
أرضه (1)

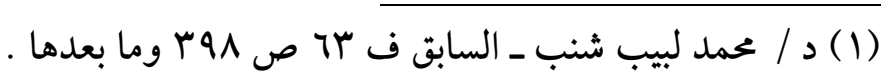

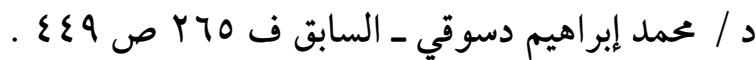

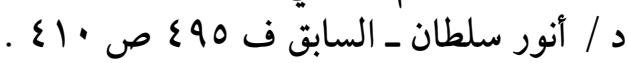

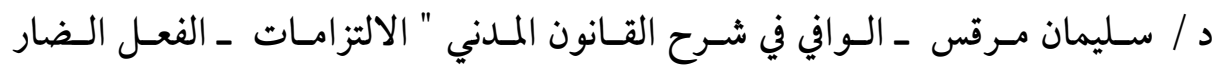

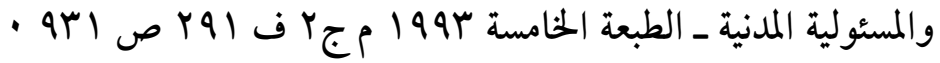




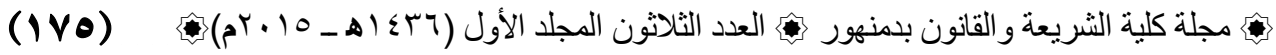

\section{المقصود بالحارس : - المار}

إذا كانت المسئولية لا تتحقق إلا إذا كان للحيوان حارس وقت حصول الضرر ، فإن هذا يدعونا لبيان المقصود بالحارس الذي يسأل عما يحدثه الحيوان إلهان

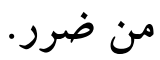

(1): ويتردد الفكر في تحديد المقصود بالحارس بين نظريتين

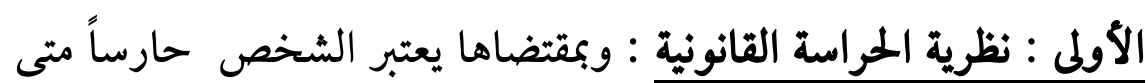

كانت له السلطة القانونية على الشيء في الاستعمال والتوجيه والرقابة ـ و وهذه

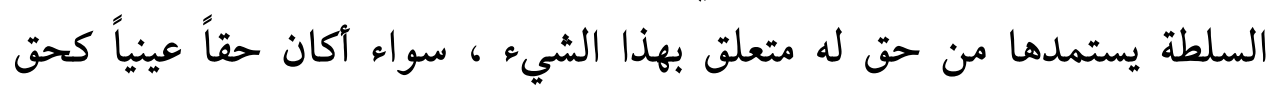

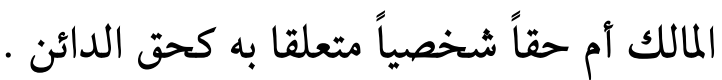

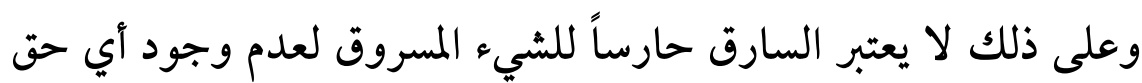

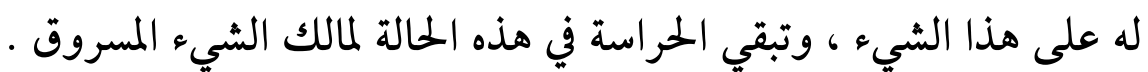

والثانية : نظرية الحراسة الفعلية : وبمقتضاها يعتبر الشخص حارسا متى على

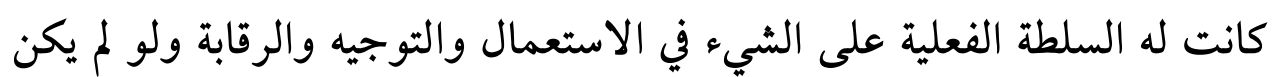

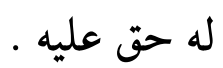

ووفقا لمذا المفهوم في تحديد معنى الحراسة ، يعتبر السارق حارسا للشيء

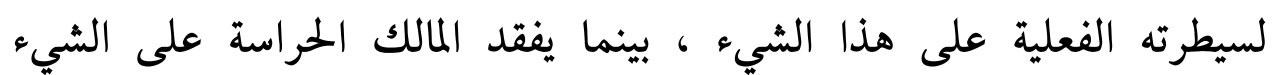

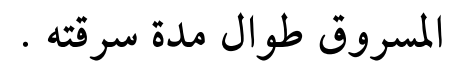

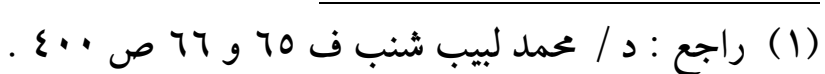

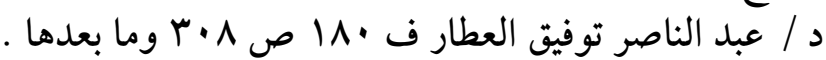

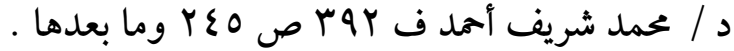


(IVฯ)

ولم يحدد المقنن المصري بأي من النظريتين السابقتين يأخذ ، كما أنه بالنظر

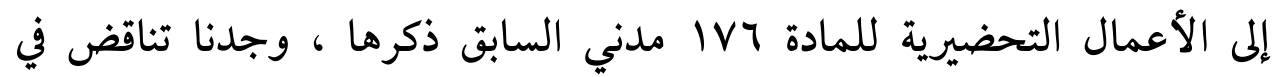
الأخذ بأي من النظريتين ، فجاء أولاً ما يلي :

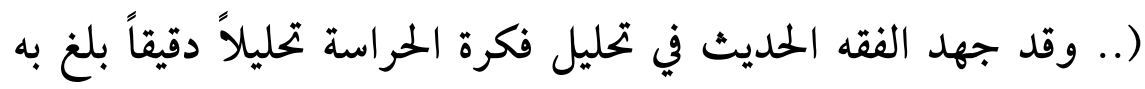

أحياناً حد الإرهاف أو التهافت ـ فهو يفرق على الأخص بين الحراسة المادية

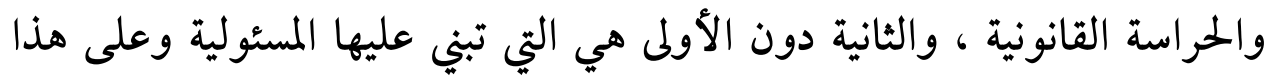

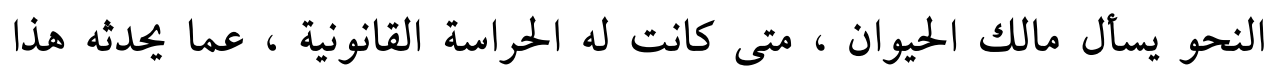

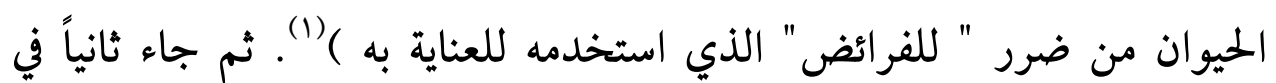
مناقشات لجنة القانون المدني بمجلس الشيوخ أن : ( التطور اتجه إلى الاعتداد

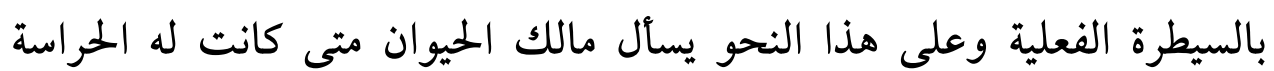
الفعلية عما يحدثه هذا الحيوان من ضرر للفر ائض الذي استخدمه للعناية به )(r). والسبب في هذا التناقض يرجع إلى أن المذكرة الإيضاحية للمشروع

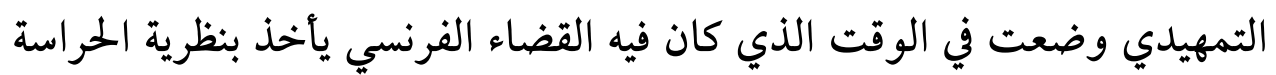

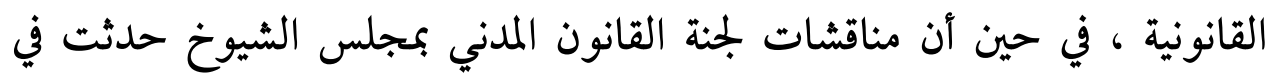

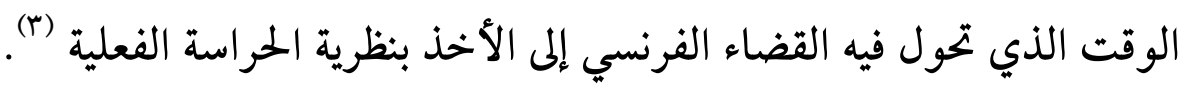

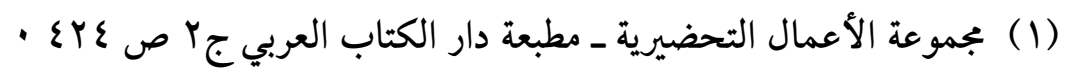

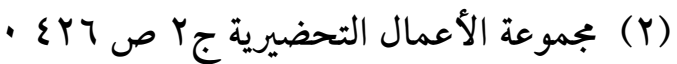

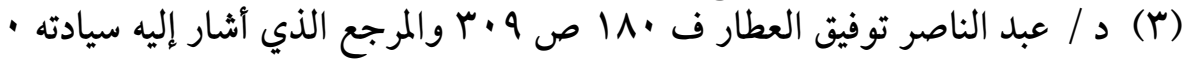


وعموما ، فإن الفقه(1) والقضاء في مصر(r) استقر على الأخذ بنظرية الحراسة الفعلية ، حيث عرف الحراسة بأنها السلطة الفعلية في الرقابة والتوجيه والتصرف • ومن ثم فحارس الحيوان الذي تقع عليه المسئولية هو من له السيطرة الفعلية على الحيوان في رقابته وتوجيهه والتصرف في أمره، ويقصد بسلطة الاستعمال : سلطة استخدام الشيء فيما أعد له بطبيعته ، فاستعمال الجمل مثلاً يكون بركوبه وليه ولئه والحمل عليه .

ويقصد بسلطة التوجيه : سلطة إصدار أوامر تتعلق باستعمال الشيء كسلطة توجيه الخيل التي تجر عربة الركوب .

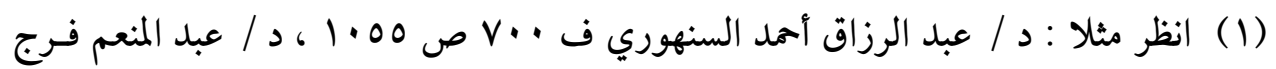

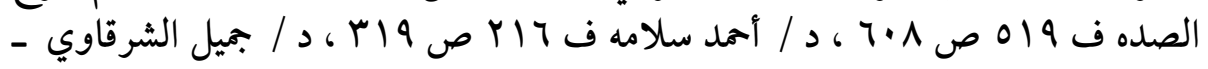

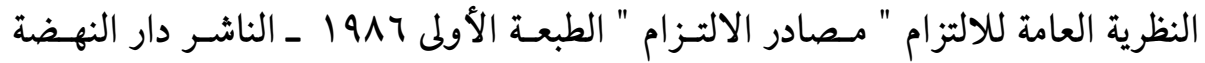

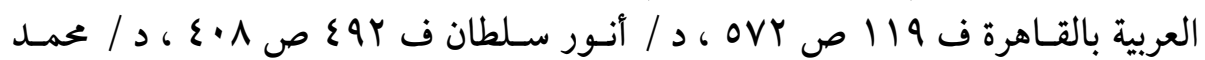

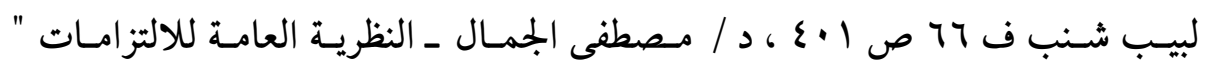

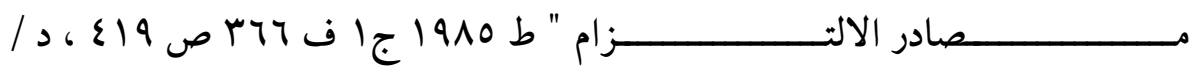

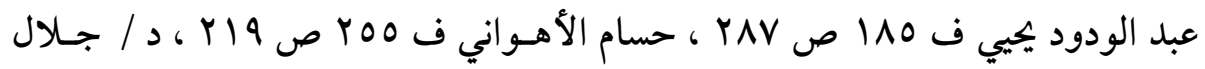

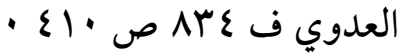

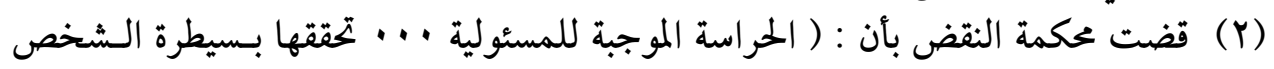

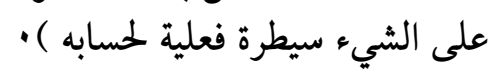

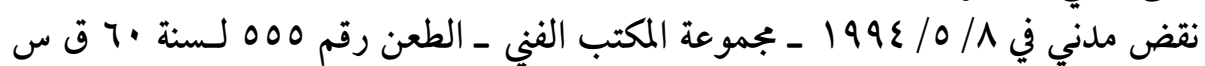
0 القاعدة رقم

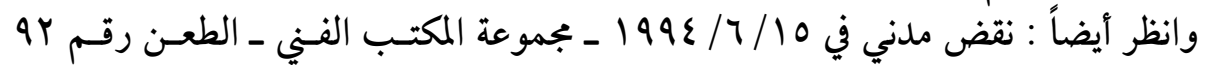

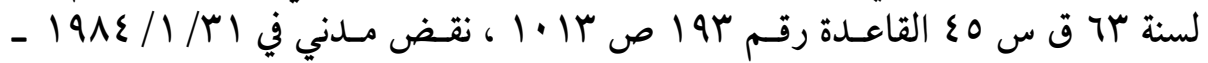

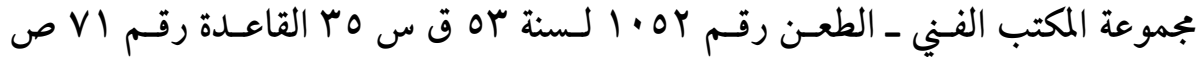

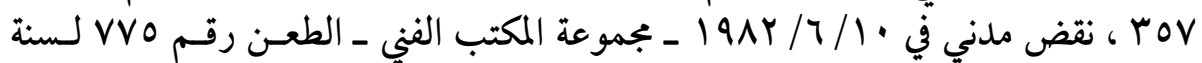

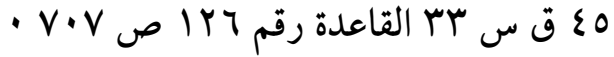


ويقصد بسلطة الرقابة : سلطة الإشراف على الشيء على نحو يهول دون

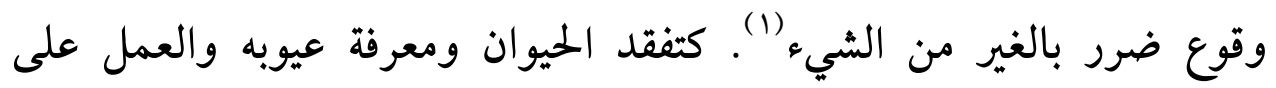
معالجتها حتى يجول دون وقوع الضرر بالغير.

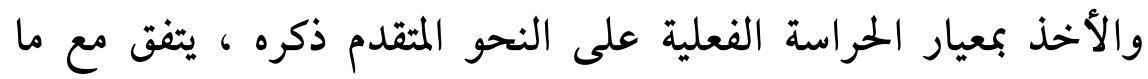

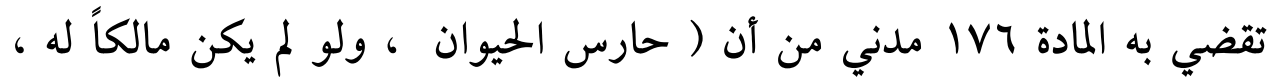

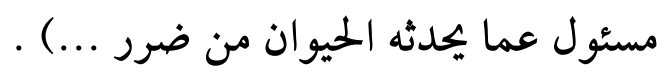
ووفقا لهذا لا يتحتم أن يكون حارس الحيوان هو مالكه ، فقد ينتقل زمام

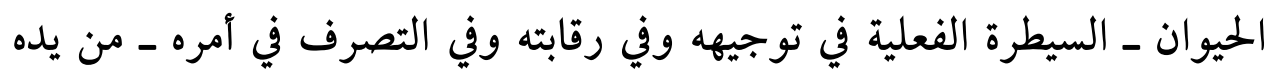

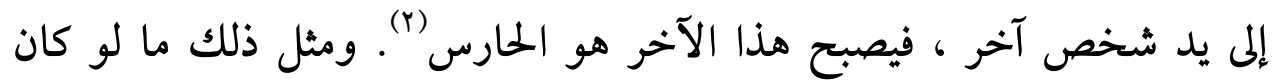

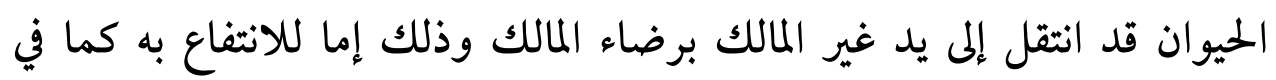

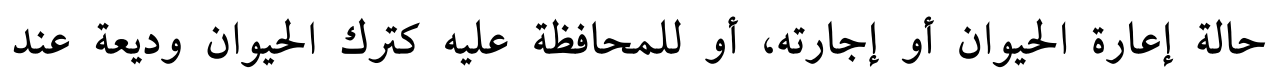

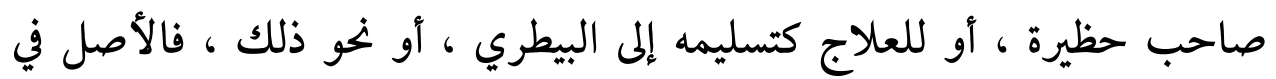

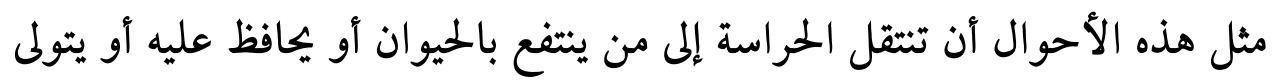

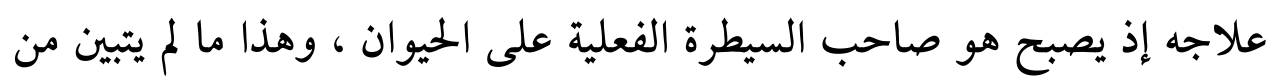

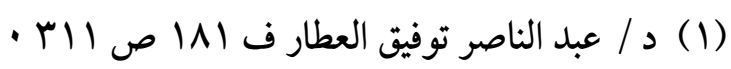

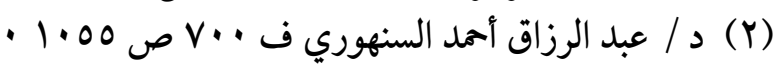

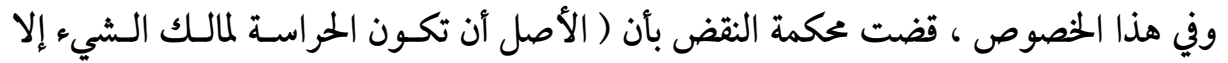

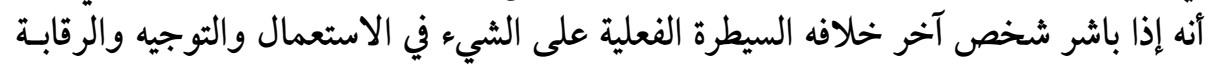

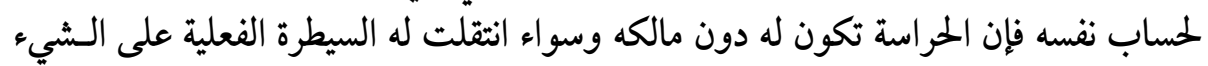

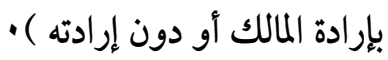

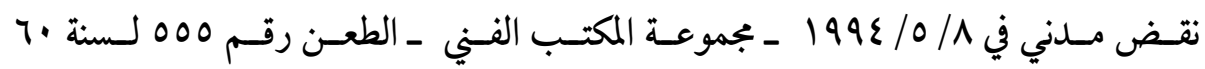

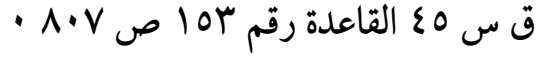


العقد وظروفه غير ذلك ، كما لو استبقى المالك لنفسه السيطرة الفعلية على

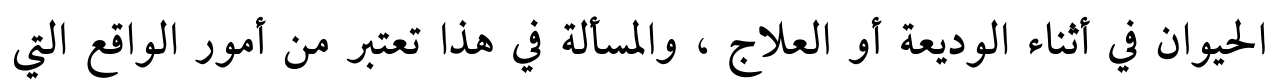

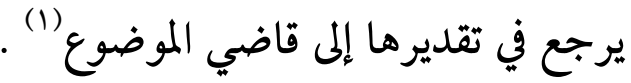
بيد أنه يلاحظ في هذا الخصوص أنه إذا انتقل الحيوان من يد المالك إلى يد

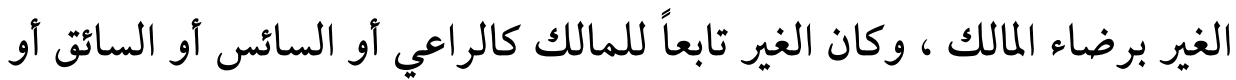

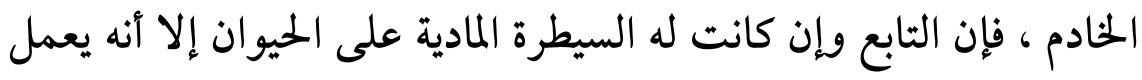

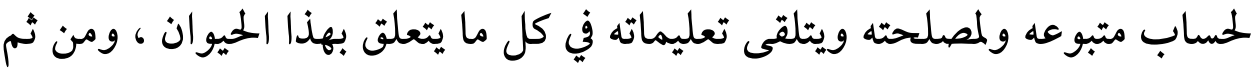

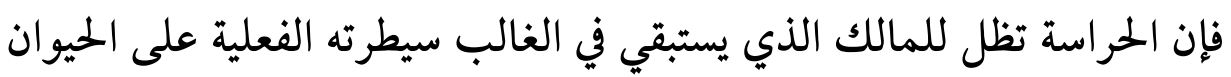

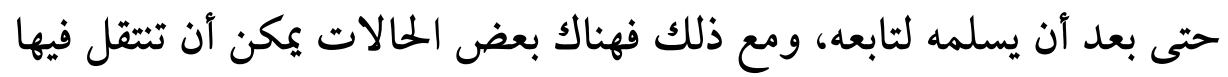

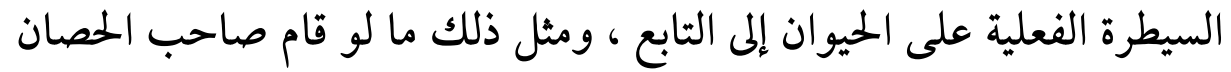

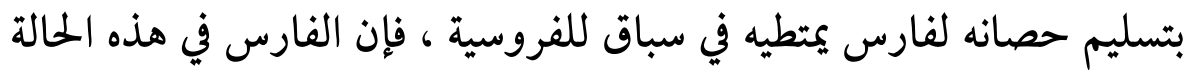

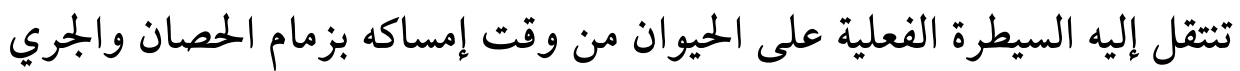

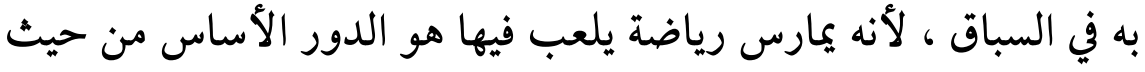

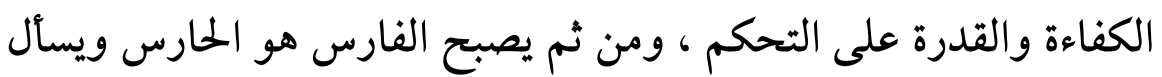

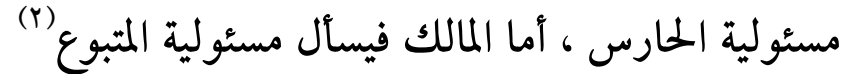

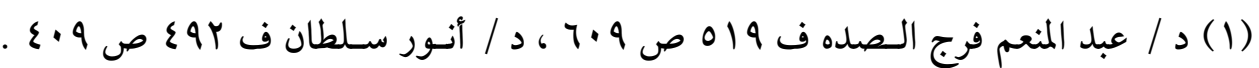

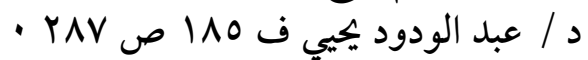

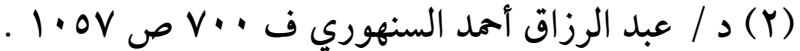

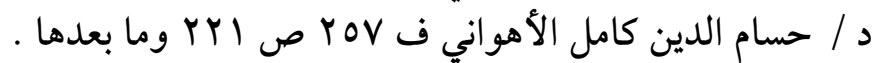

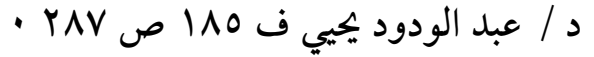


وقد تتتقل السيطرة الفعلية في توجيه الحيوان ورقابته والتصرف في أمره

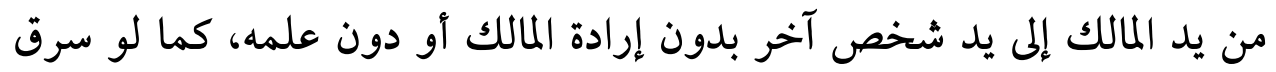

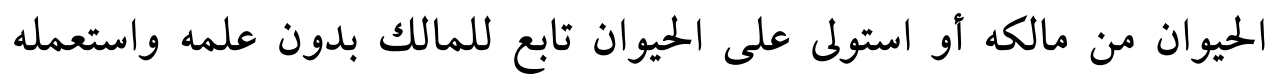

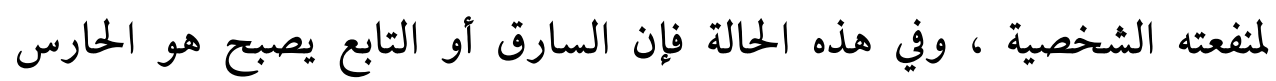

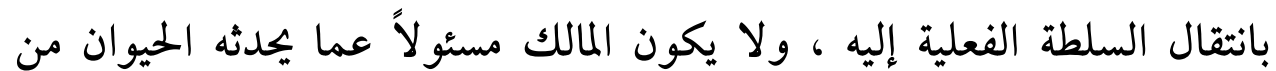
ضرر ، وإنما يكون المسئول هو السارق أو التابع (1). وإذا كان لا يتحتم أن يكون حارس الحيوان هو مالكه على الوجه السابق

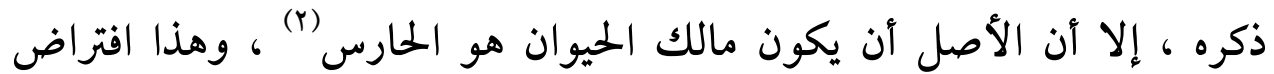

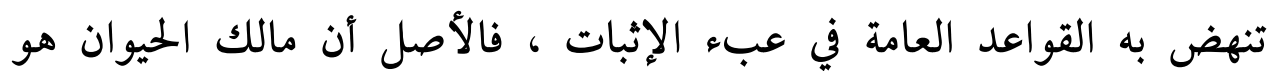

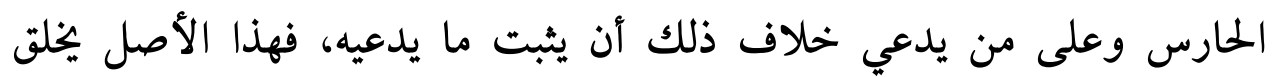

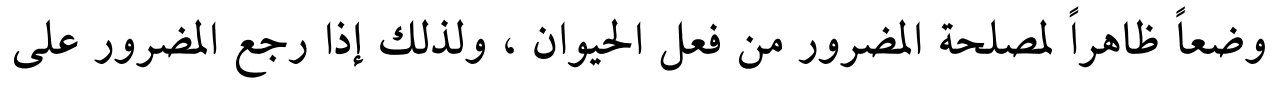

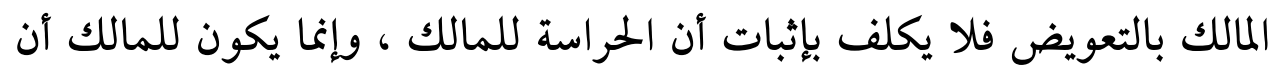
يثبت أن الحراسة كانت لغيره وقت حدوث بلث الضرر ، أي يثبت أن السيطرة الفعلية

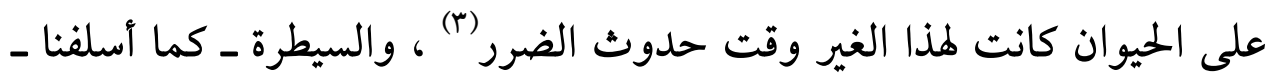

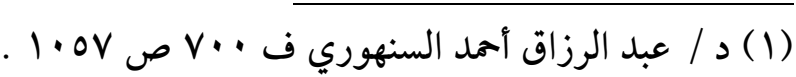

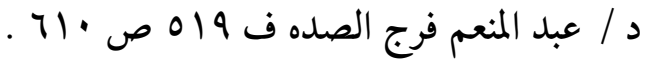

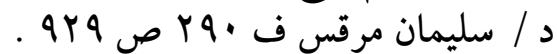

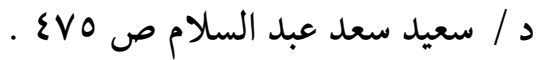

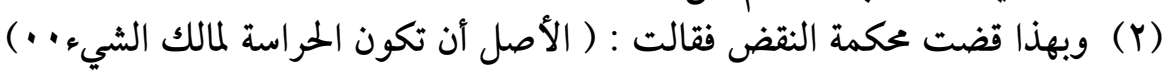

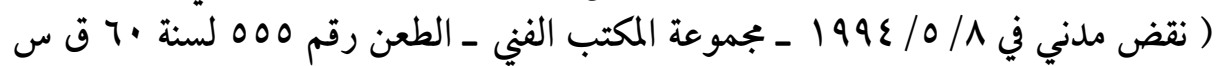

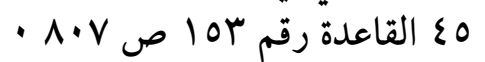

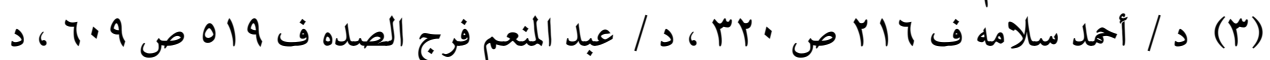

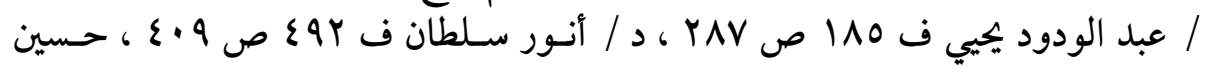


قد تنتقل إلى هذا الغير إما برضاء المالك وإما بدون رضاه . وإذا لم تنتقل الحراسة من المالك إلى الغير ، فإن المالك يظل مسئولاً عن

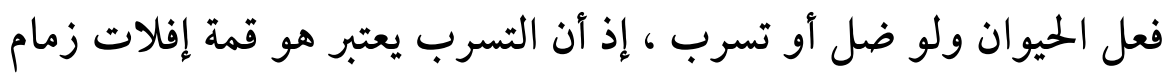

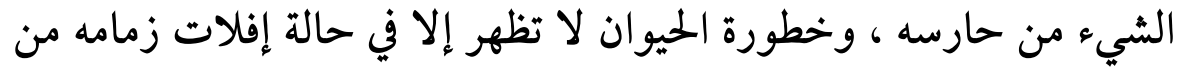

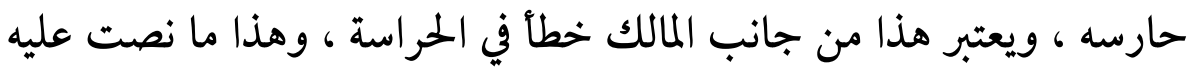

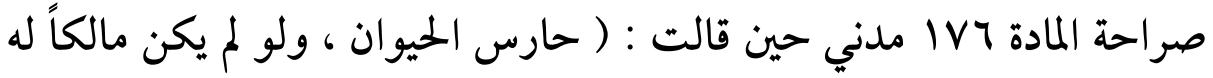

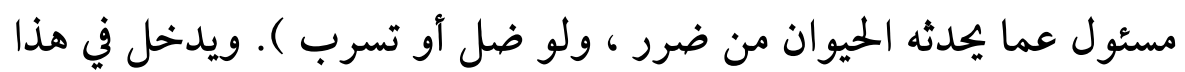

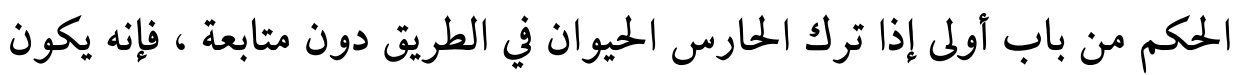

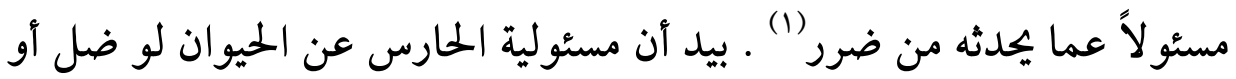

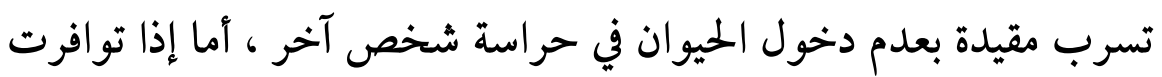

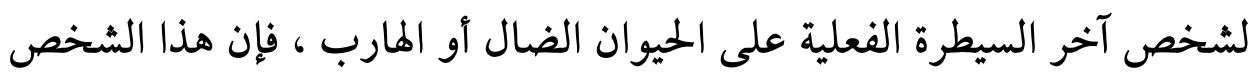

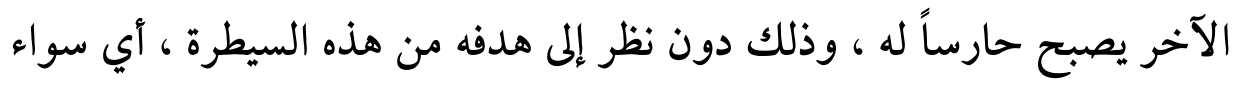

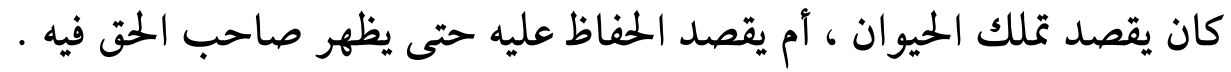

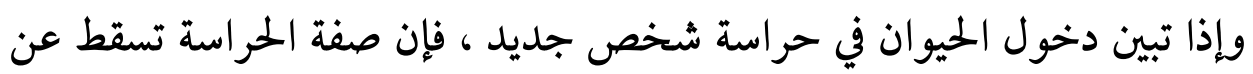
حارسه السابق (r)

$$
\begin{aligned}
& \text { عامر وعبد الرحيم عامر ـ المسئولية المدنية " التقصيرية والعقدية " الطبعة الثانيـة } 1919
\end{aligned}
$$

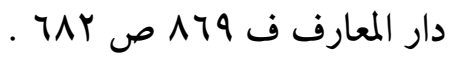

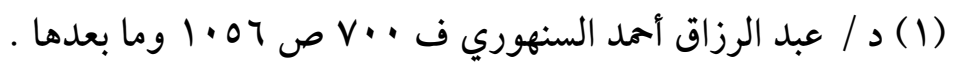

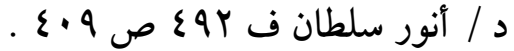

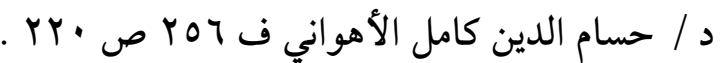

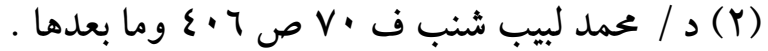




\section{هدى اشتراط التـييز في الحارس}

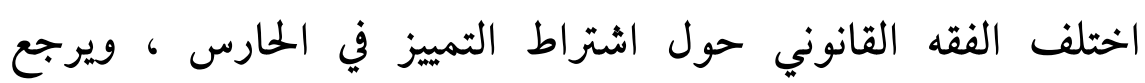

اختلافهم إلى الاختلاف حول الأساس القانوني للمسئولية عن الأشياء (1).

فذهب رأي (r) إلى اشتراط أن يكون الحارس ميزاً ، لأن مسئولية الحارس

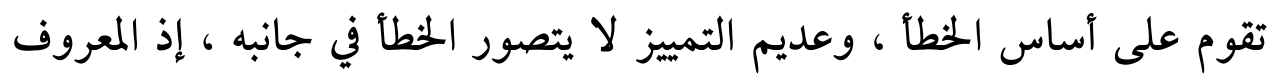

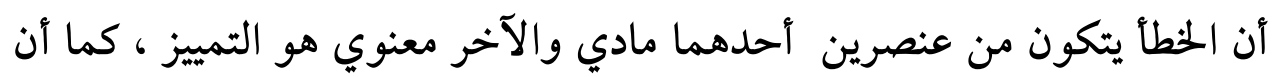

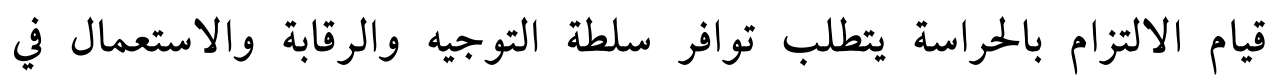

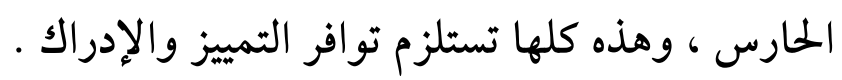

وذهب رأي آخر (r) إلى عدم اشتراط التمييز في الحارس ، لأن المسئولية

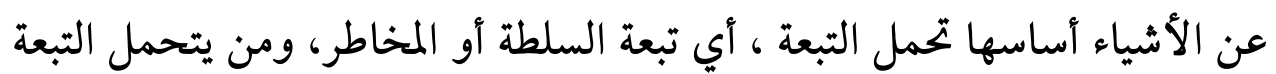
لا يشترط فيه أن يكون ميزاً .

وقد أخذ أصحاب هذا الرأي على أصحاب الرأي الأول ، بأن القول أن

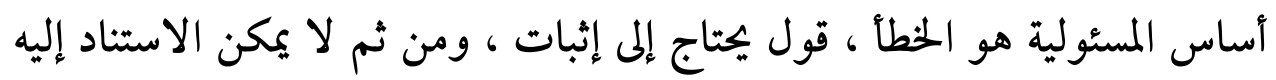

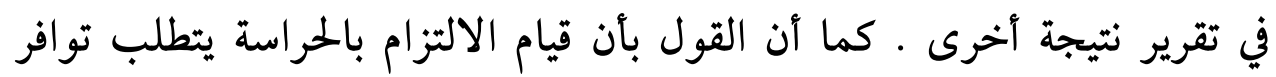

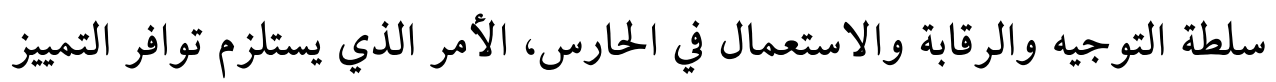

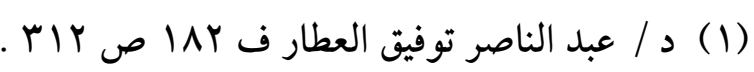

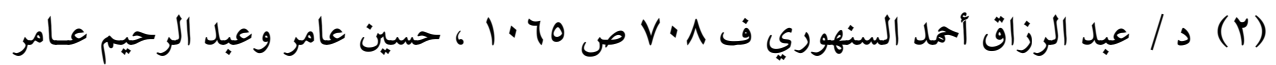

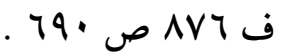

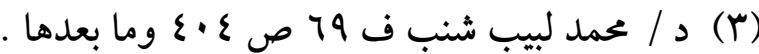

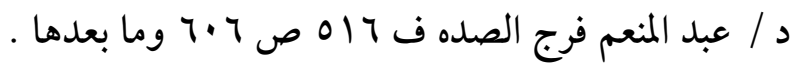

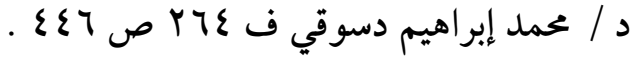


والإدراك ، فهذا أيضاً غير ثابت ، لأن السيطرة الفعلية وهي مناط الحراسة يمكن

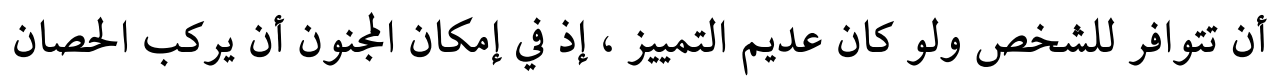

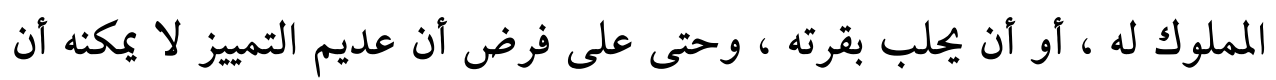

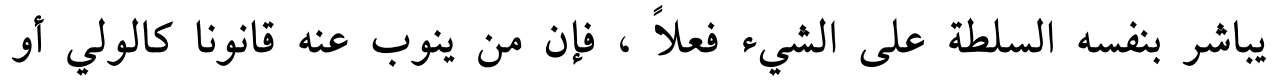

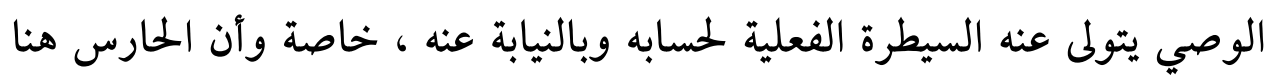

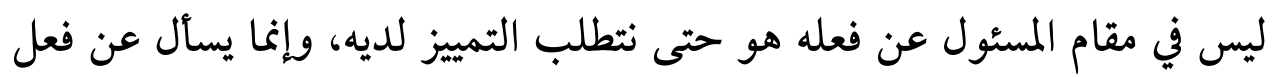

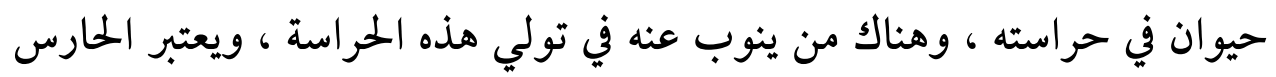

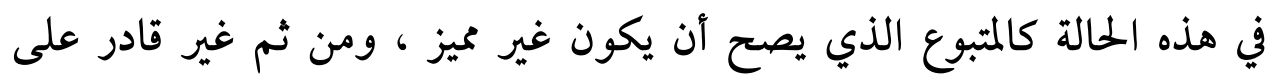

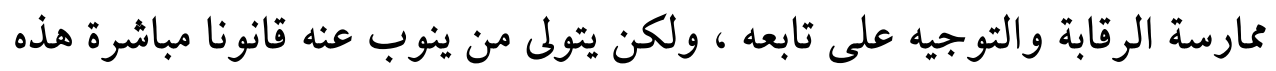

السلطة (1)

\section{انقضاء الهراسة : - إس}

وفقا للتعريف الذي استقر عليه الفقه للحراسة بأنها السيطرة الفعلية على الحيوان في رقابته وتوجيهه والتصرف في أمره ، فإن من يفقد هذه السيطرة الفعلية

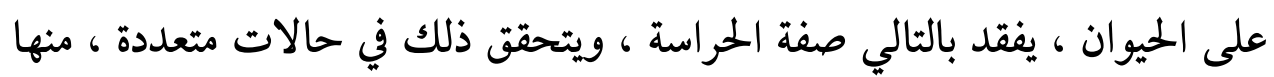

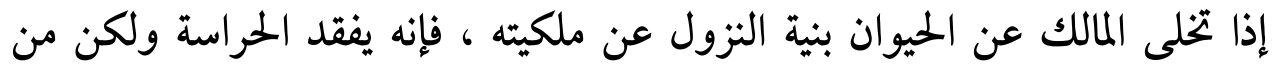

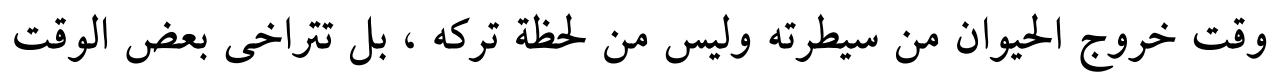

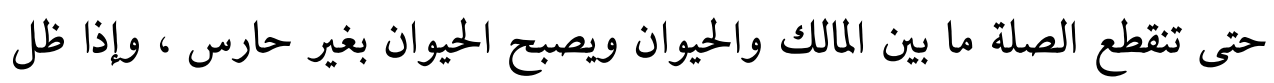

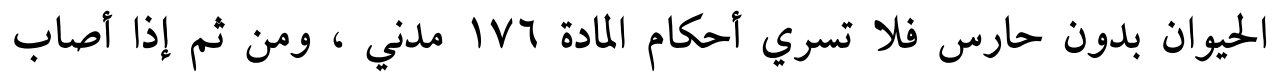

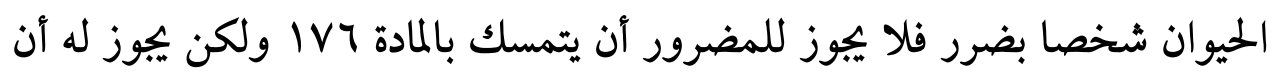


$(1 \wedge \varepsilon)$

يتمسك بالمسئولية عن العمل الشخصي على اعتبار أن ترك الحيوان دون احتياط يعد

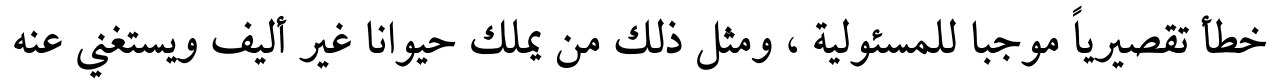

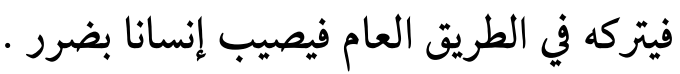

ولا يصبح من يلتقط الحيوان المتروك حارساً له إلا بعد أن يستقر عنده ، ومن ثم إذا أشفق إنسان على كلب في الطريق فحمله ووضعه في مأمن وكان التهان

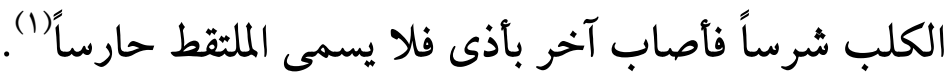
ويجب التفرقة بين ترك الحيوان أي التخلي عن ملكيته وبين ما إذا كان

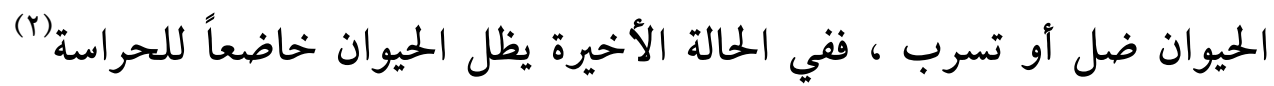

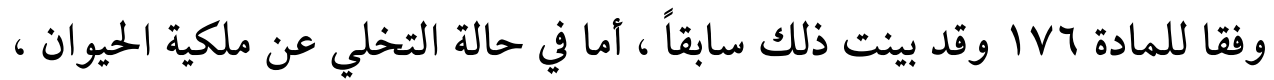
فإن مالكه يفقد حراسته من وقت خروج الحيوان من سيطرته .

وقد يفقد الشخص السيطرة على الحيوان وبالتالي صفة الحراسة دون أن

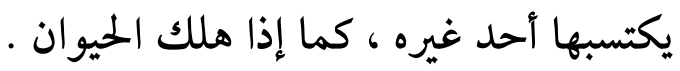

وقد يتم انتقال الحراسة بنص القانون كما لو توفى الحارس وانتقلت

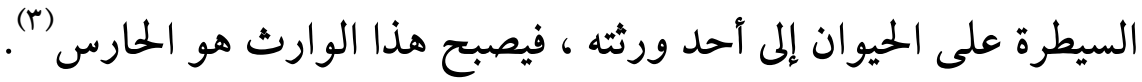
وقد تنتقل الحراسة بناء على تسليم الحيوان في عقد ناقل للملكية، كعقد

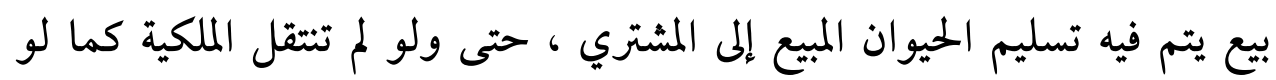

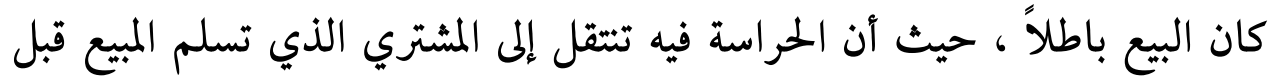

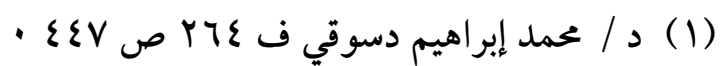

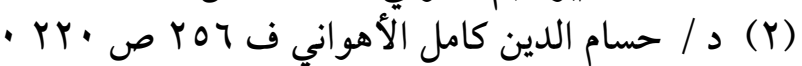

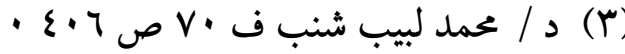




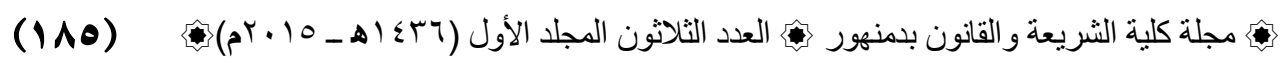
إعادة العاقدين إلى الحالة التي كانا عليها قبل التعاقد، أو كان البيع بشرط التجربة،

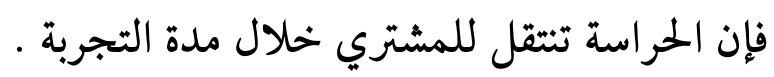

كما قد يتم انتقال الحراسة بناء على تسليم الحيوان في عقد ينقل حقا

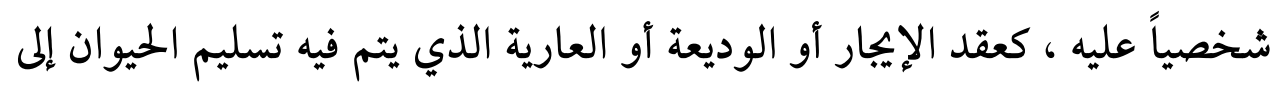
المستأجر أو المودع لديه أو المستعير. وأخيراً قد تنتقل الحراسة على الرغم من إرادة الحارس كما لو سرق الحيوان منه ، وفي هذه الحالة يصبح السارق حارساً للحيوان ، ومسئولاً عما يحدثه للغير من ضرر (1) 


\section{المطلب الثاني}

\section{تحليد الضامن لفعل الحيوان في الفقه الإسلامي}

الضامن لفعل الحيوان في الفقه الإسلامي هو صاحب اليد على الحيوان .

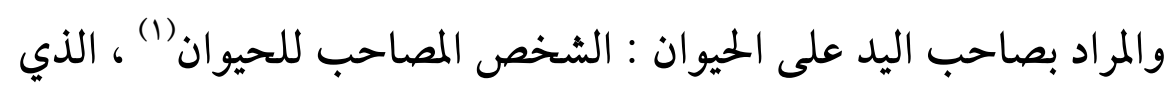

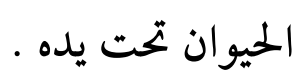

و التعبير بصاحب اليد على الحيوان أولى من التعبير بصاحب الحيوان، لأن التعبير بصاحب الحيوان يظهر منه اقتصاره على مالكه

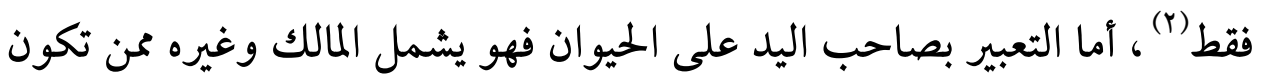

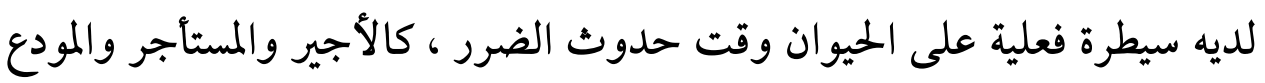

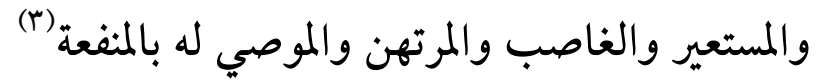

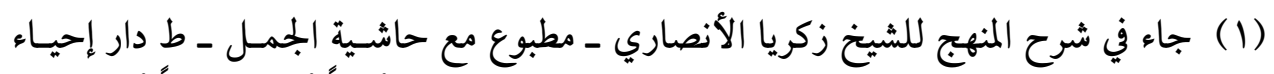

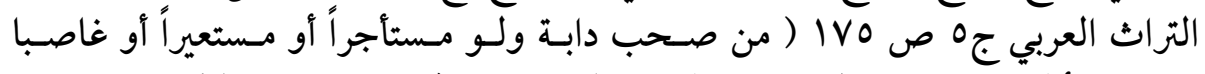

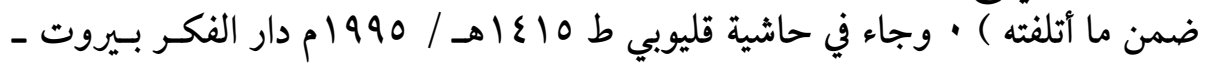

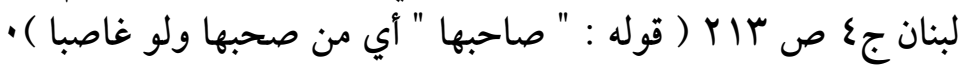

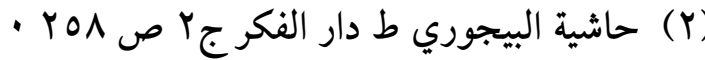

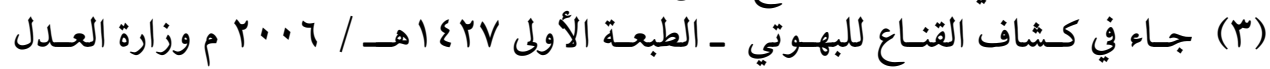

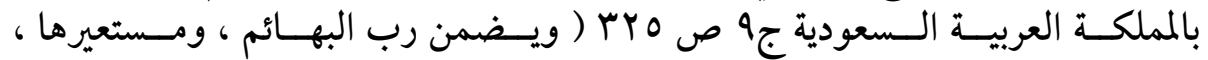

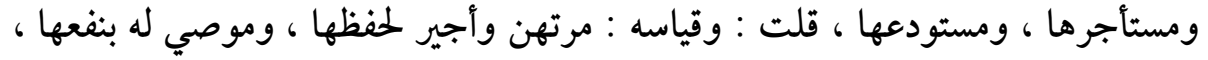

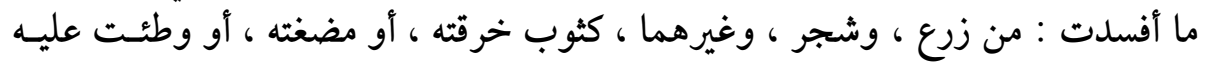

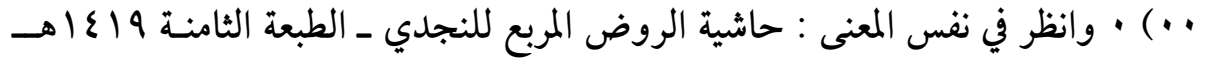

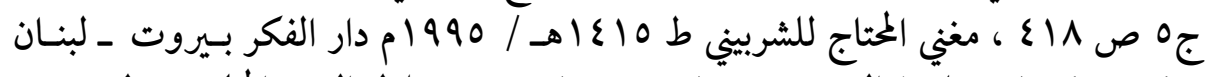

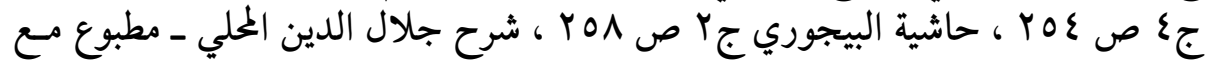


وعلى ذلك فكل من تكون يده على الحيوان يجب عليه تعهده وحفظه ، فإذا

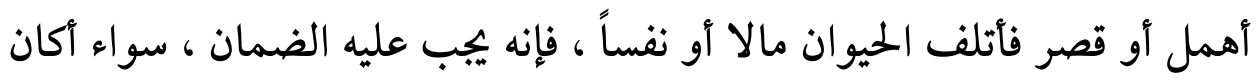

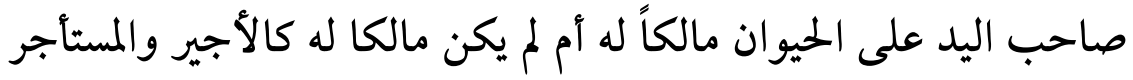
والمستعير والمودع والمرتهن والغاصب ، وسواء أكان سائقه أم راكبه أم قائده (1).

$$
\text { والساتق للحيوان : هو الحاث له على السير. }
$$

وكيفية ضمان السائق والقائد والراكب : أن كل واحد من الثلاثة مخاطب

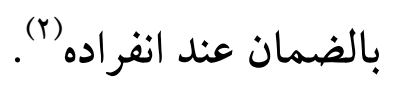

وعند اجتماع السائق والقائد دون الراكب ، فإن الضمان يكون بينهما نصفين،

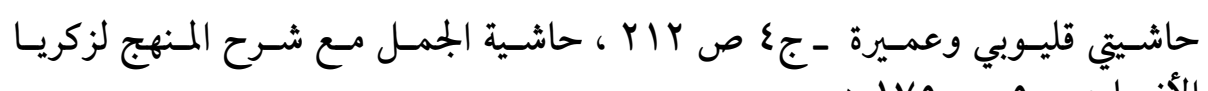

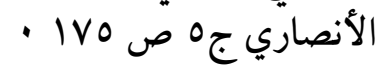

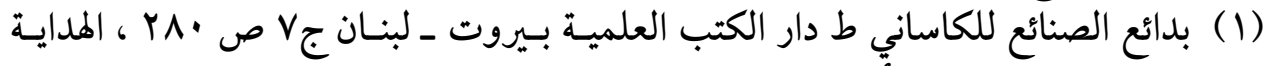

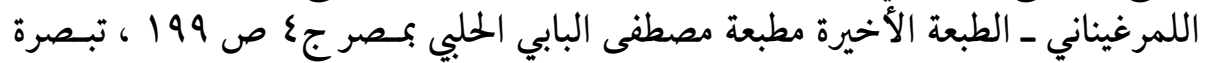

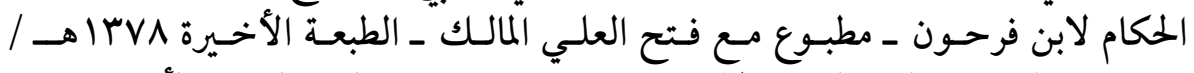

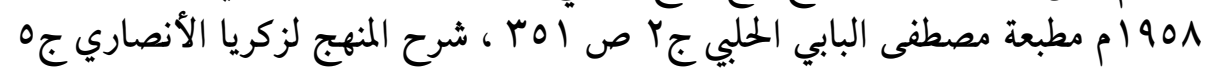

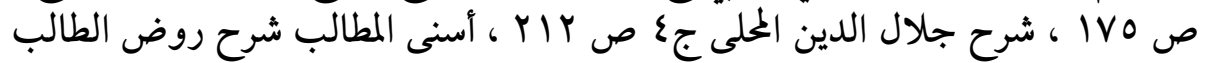

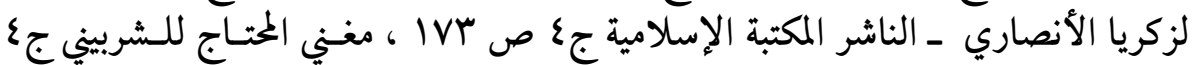

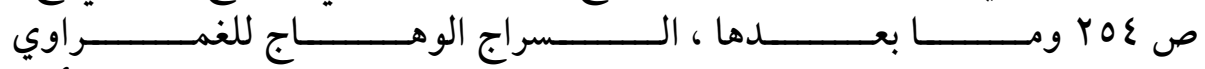

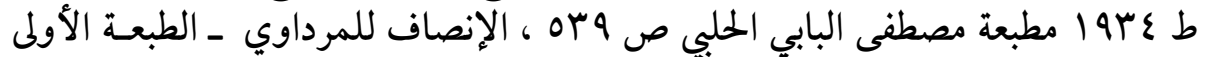

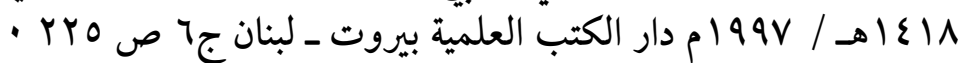

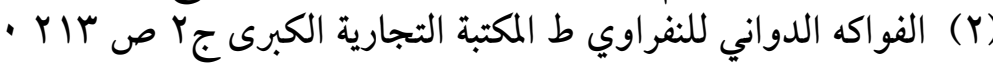


لأن كل واحد لو انفرد ضمن ، فإذا اجتمعا ضمنا" .

أما عند اجتماع الثلاثة ـ السائق والقائد والراكب ـ فقد اختلف الفقهاء في

كيفية الضمان ، على ثلاثة أقوال :

القول الأول : ذهب الحنفية(r) والشافعية(r) في وجه والحنابلة (ع) في صحيح

المذهب إلى أن الثلاثة يشتركوا في الضمان .

بيد أن الحنفية أوجبوا الكفارة على الراكب وحده فيما وطئت دابته إنسانا فقتلته لوجود القتل منه وحده مباشرة ، ويحرم من الميراث والوصية.

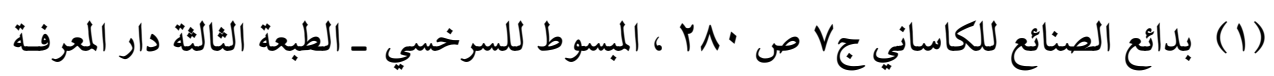

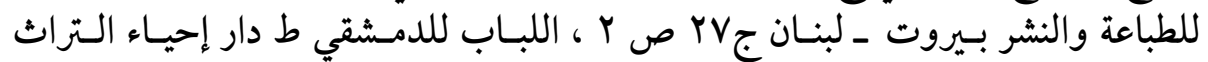

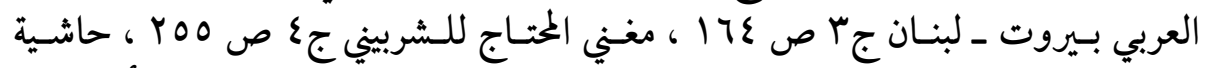

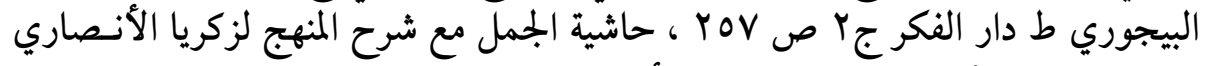

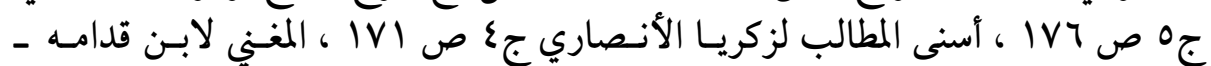

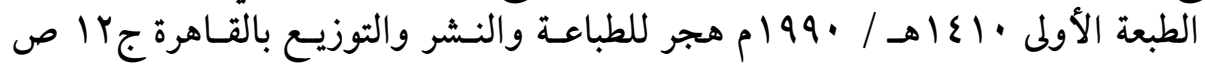

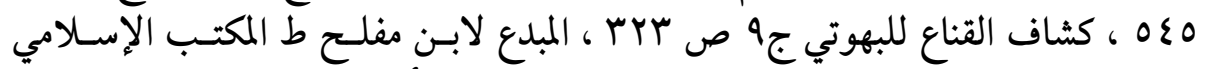

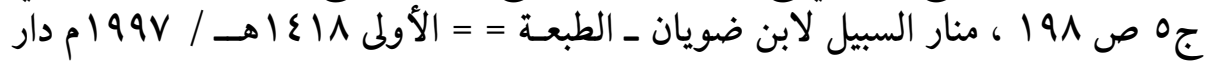

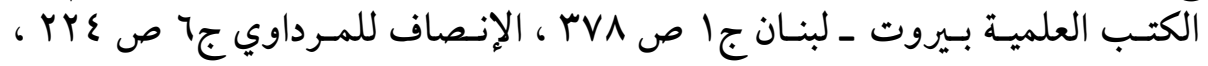

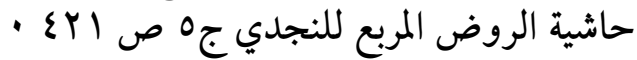

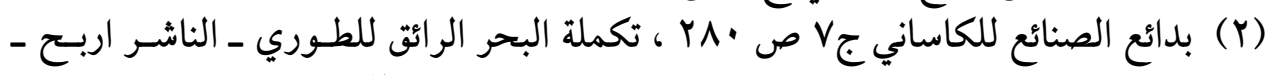

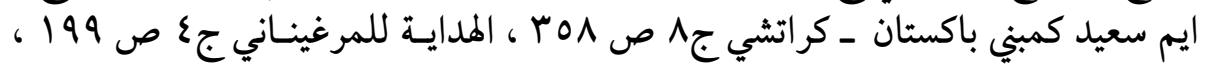

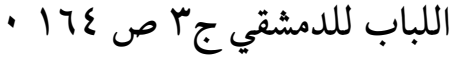

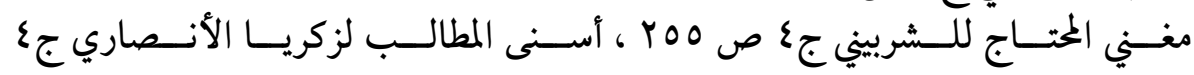

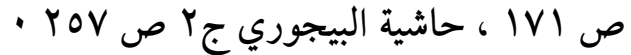

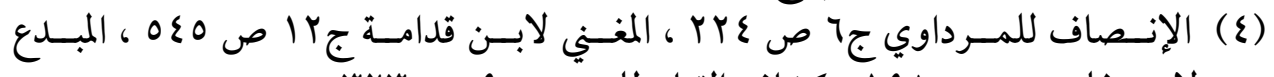

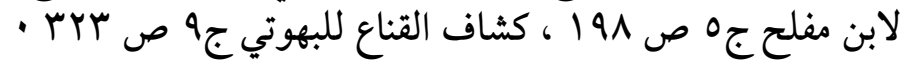




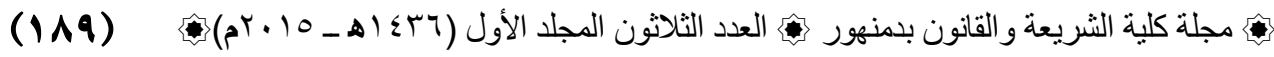

ووجه مذا القول : أن كل واحد من الثلاثة اشترك في التصرف ، كما أن

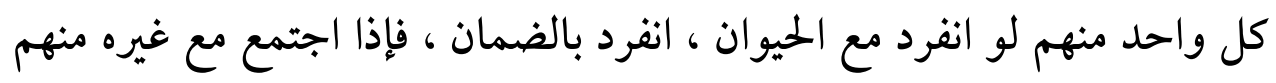

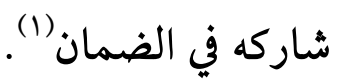

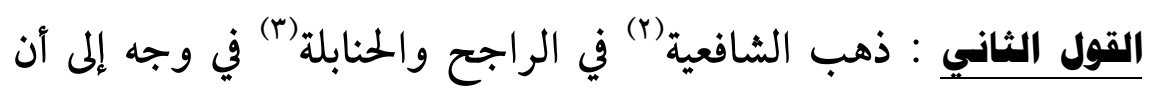
الضمان يختص بالر اكب دون القائد والسائق .

ووجه هذا القول : أن سير الحيوان ينسب إلى الراكب لأنه أقوى يداً

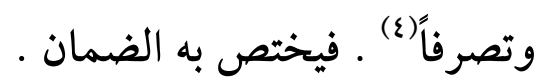

القول الثالث : ذهب المالكية (o) إلى أن الضمان يكون على القائد والسائق

$$
\text { ولا شيء على الراكب إلا إذا كان الإتلاف بسببه . }
$$

ووجه مذا القول : أن الراكب بمنزلة المتاع الكائن على ظهر الحيوان ، فلا

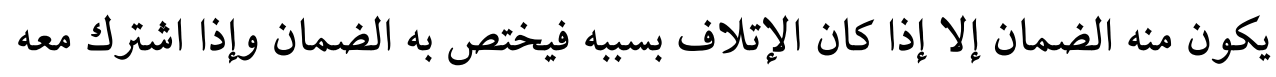

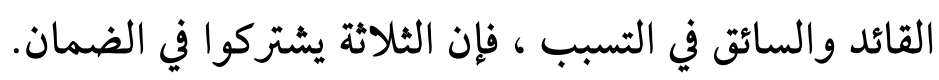
وأرى وجاهة القول الأول الذي يرى اشتراك الثلاثة في الضمان ، لأنهم

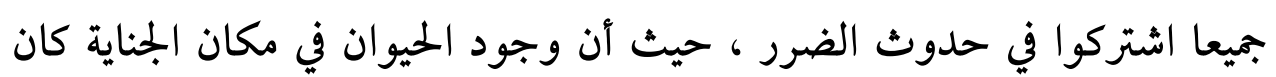

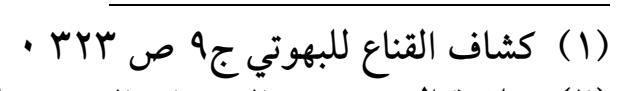

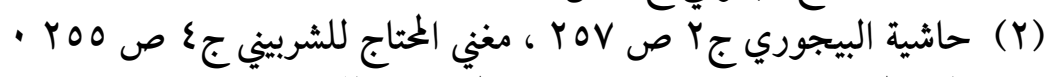

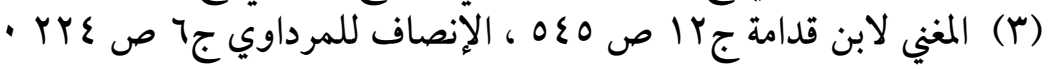

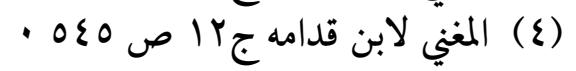

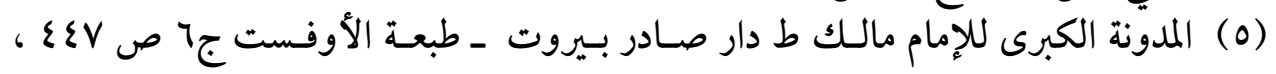

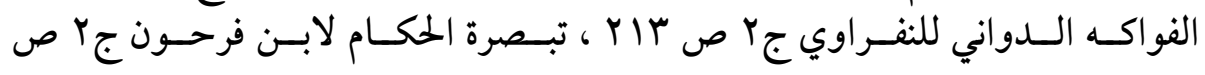


بفعلهم جميعا ، ومن ثم فإن التلف فيما يمكن التحرز عنه كان بسببهم جميعا فيشتركوا في الضمان . ت فيعان

ويلاحظ أنه لا يشترط أن يكون صاحب اليد على الحيوان مكلفا ، فلو

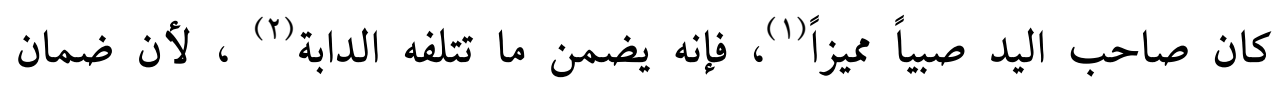

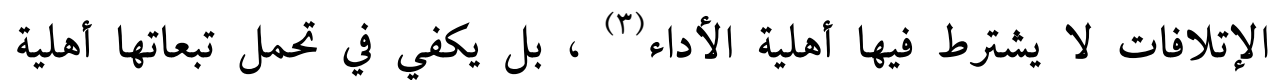

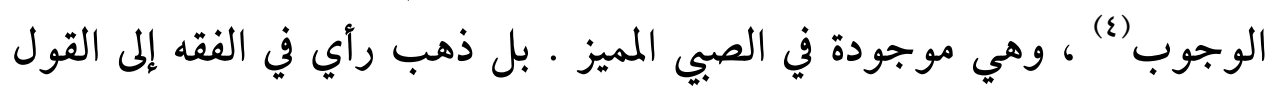

(1) يكون الصبي مميزاً عند إتمامه السابعة من عمره ، وإذا كلـم بـشيء مـن مقاصـد العقـلاء

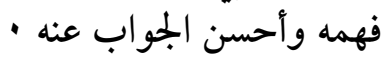

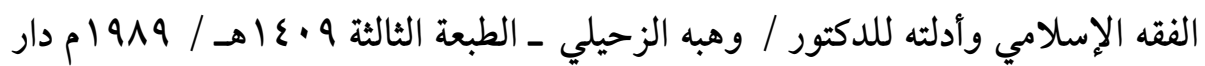

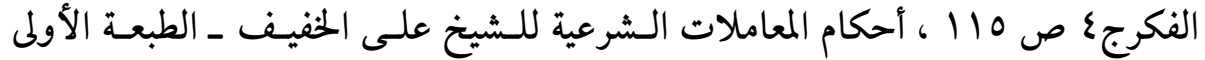

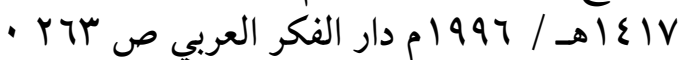

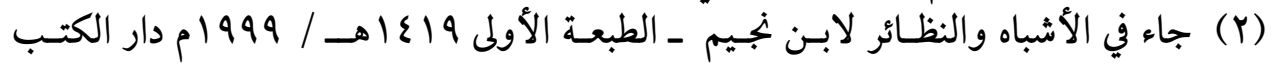

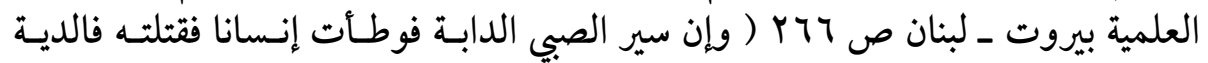

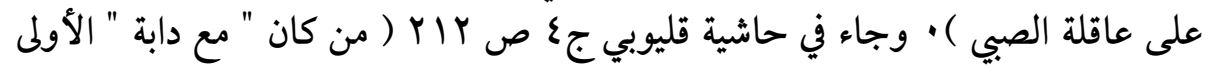

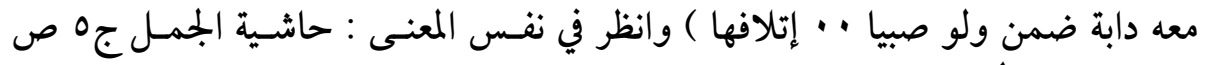

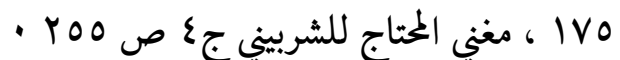

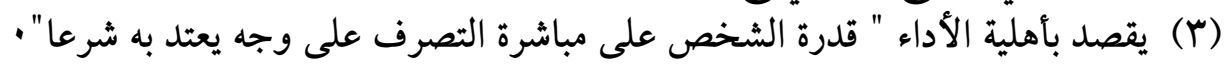

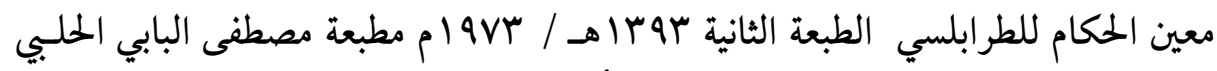

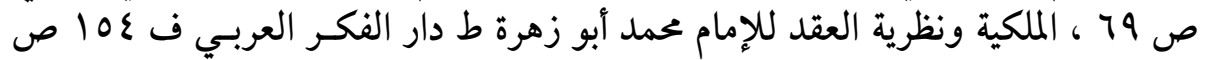
. r. $r$

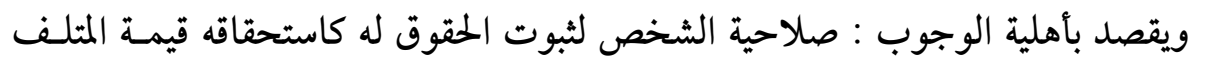

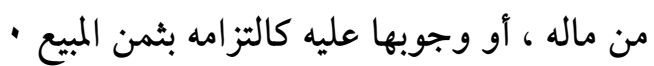

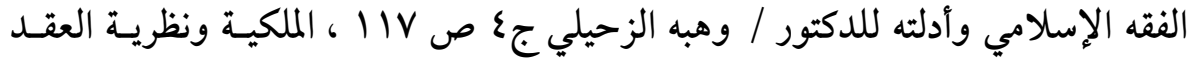

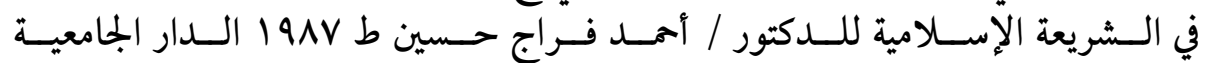




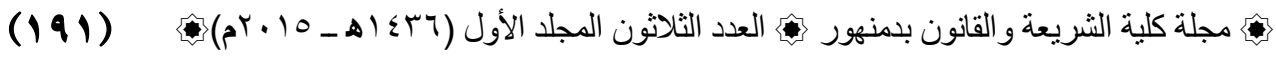
بضمان الصبي للتلف حتى ولو كان غير ميز (1). بيد أنه إذا ركب الصبي الدابة بمعرفة الولي ، فإنه يشترط لضمانه أن تكون هناك مصلحة في إركابه بأن يكون ممن يضبط الدابة وإلا ضمن الولي (r).

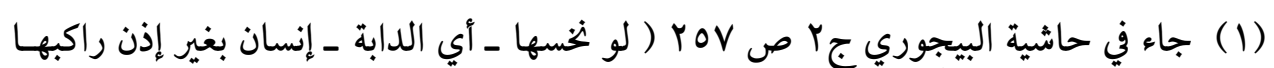

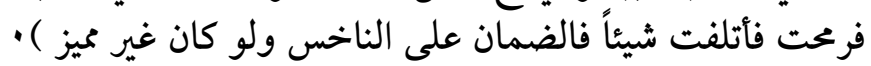




\section{المطلب الثالث}

\section{الموازنة بين القانوز الملدني والفقه الإسلامي في تحليد المسئول عن فمل الحيوان}

بالنظر في تحديد المسئول عن فعل الحيوان في القانون المدني والفقه

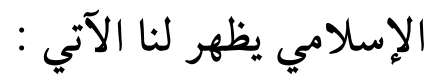

أ ـ أن المسئول عن فعل الحيوان في القانون المدني هو حارس الحيوان، وهو

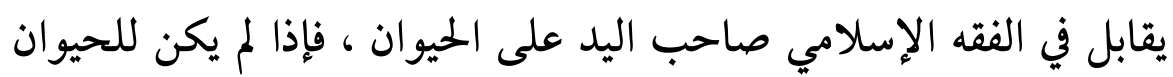

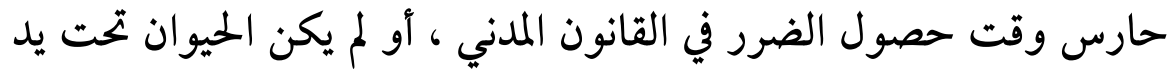
شخص في الفقه الإسلامي ، فلا تنطبق أحكام المسئولية في القانون المدني

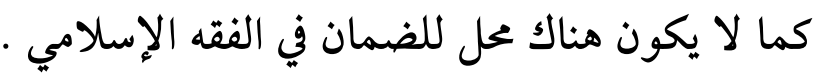

ب - ـيتردد الفكر القانوني في تحديد المقصود بالحارس بين نظريتين، نظرية

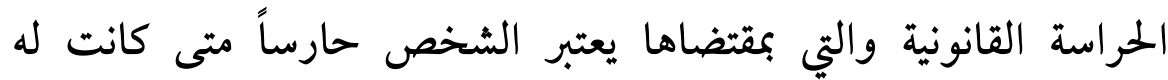

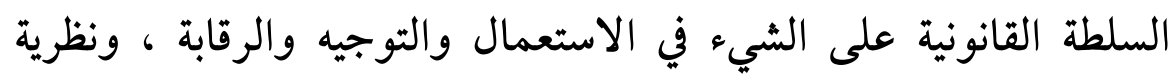

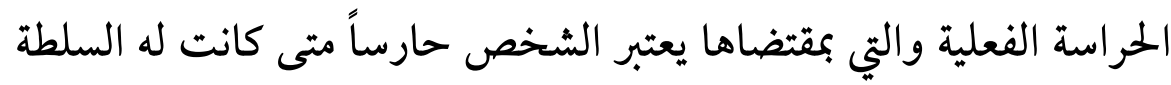

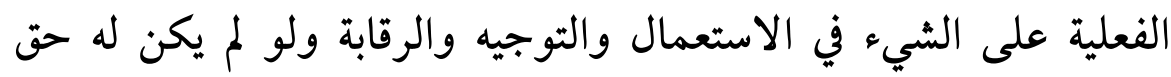

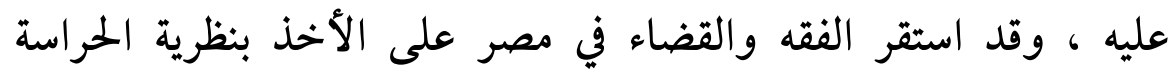

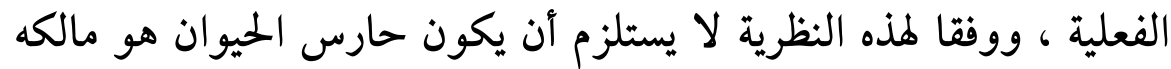

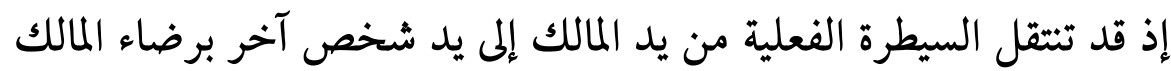

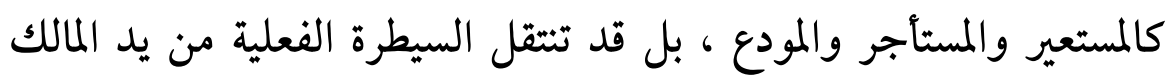

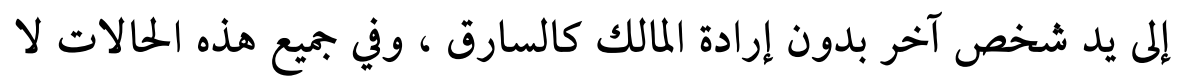




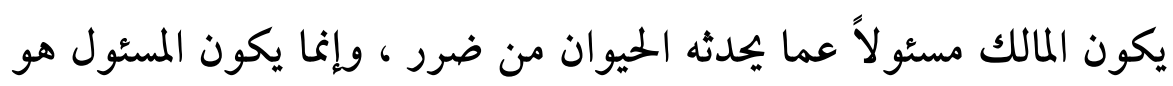

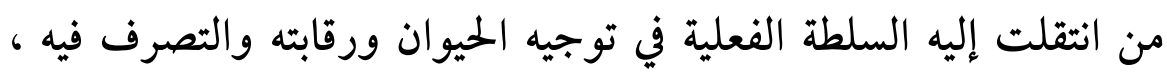

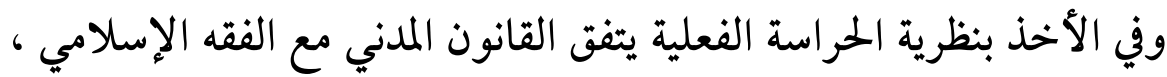

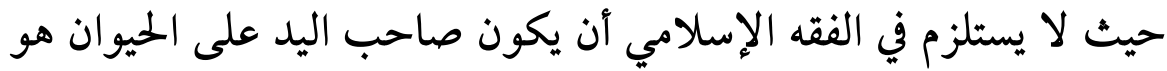

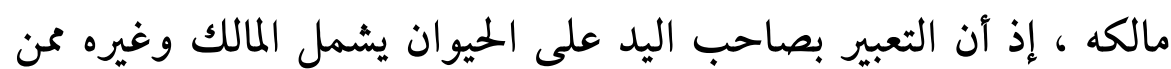

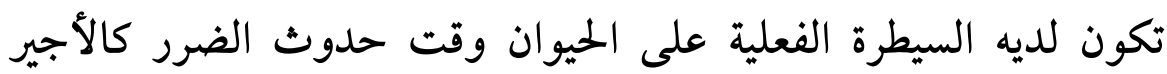

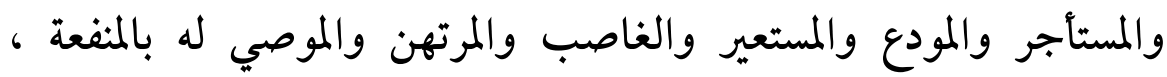
وسواء أكان سائقه أم راكبه أم قائده.

ج - ذهب الفقه القانوني إلى أن الحارس يكون مسئولاً عن فعل الحيوان حتى

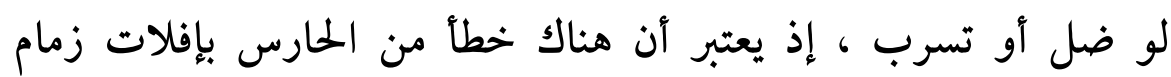

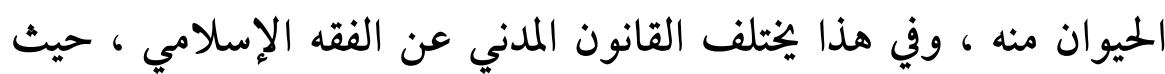

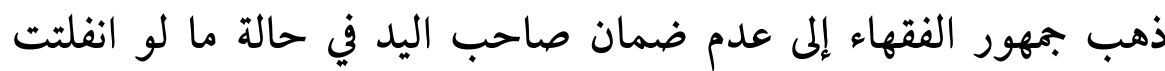

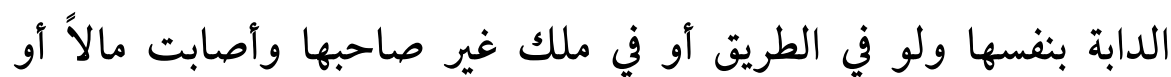

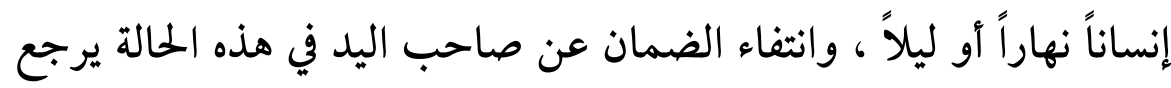

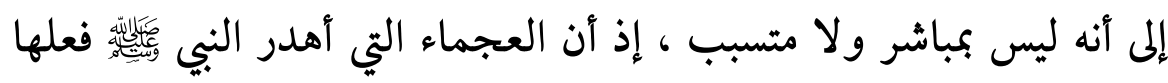
هي المنفلتة .

ولا شك أن ما ذهب إليه جمهور الفقهاء هو ما يتفق مع مقتضيات العدالة ،

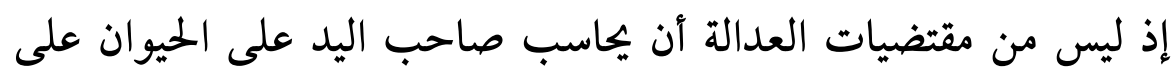

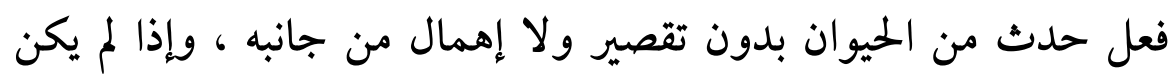
إسناد فعل الحيوان إلى صاحب اليد عليه ، فإنه يكون هدر. 
دـ ـ ذهب الفقه الإسلامي إلى أنه لا يشترط أن يكون صاحب اليد على الحيوان

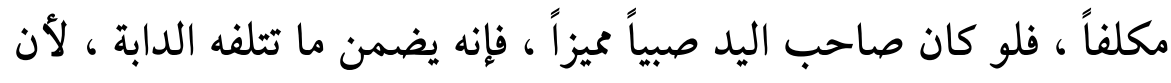

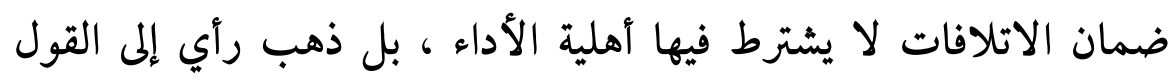

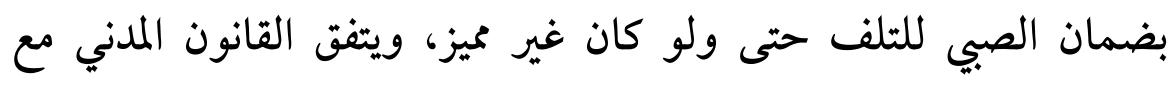
الفقه الإسلامي في هذا الخصوص ، فيجوز في ولي القانون المدني أن يكون

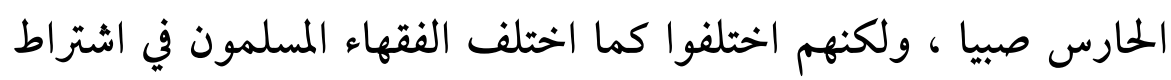

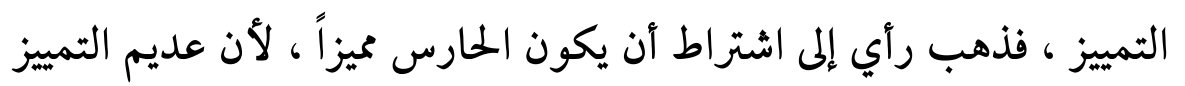

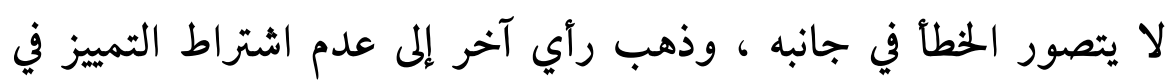

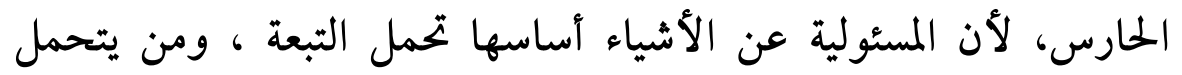
التبعة أو المخاطر لا يشترط فيه أن يكون ميزاً. 


\section{المبحث الثاني}

\section{شروط قيام المسئولية عن فعل الحيوان}

وينقسم إلى ثلاثة مطالب :

\section{المطلب الأول}

\section{شروط قيام المسئولية عن فعل الحيوان في القانوز الملدني}

يلزم لتحقق المسئولية عن فعل الحيوان في القانون المدني ، أن يكون

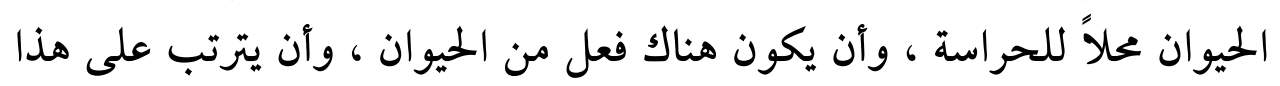
الفعل ضرر الغير.

وقد تكلمنا بالتفصيل عن الشرط الأول عند الحديث عن تحديد الشخص

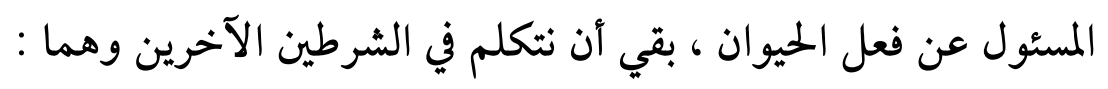
1 - و وجود فعل من الحيوان . r ـ أن ينتج ضرر من الحيوان للغير.

\section{أولاً : وجود فعل هن الحيوان :}

يجب أن يكون الحيوان قد أتى عملاً إيجابياً كان هو السبب في إحداث إنداث

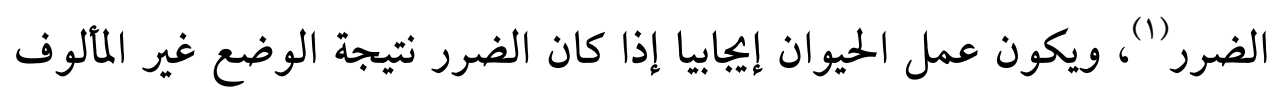

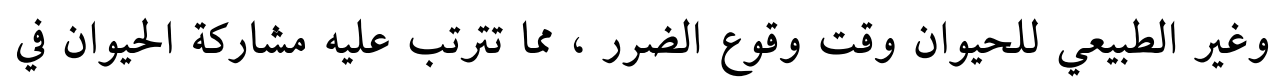

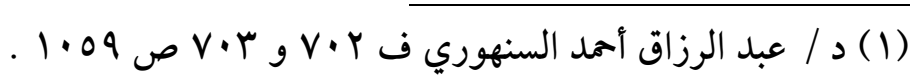

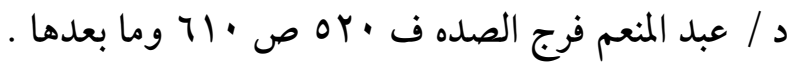


حدوث الضرر(1) ، ويستوي في هذه الحالة أن يكون الحيوان قد اتصل اتصالاً

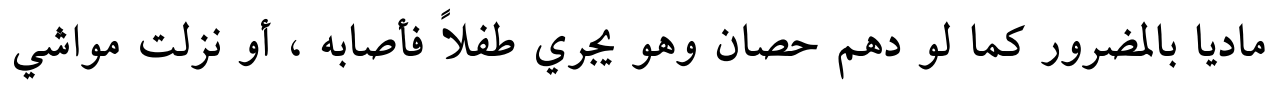

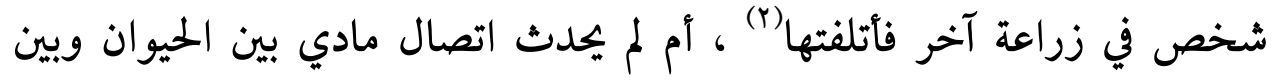

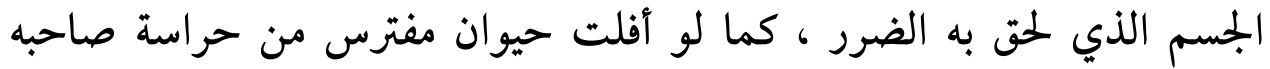

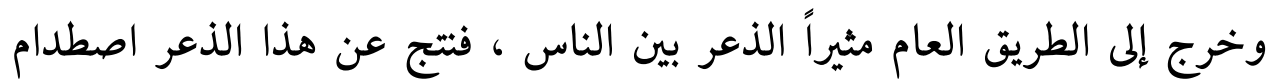

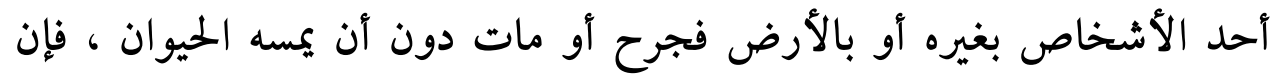

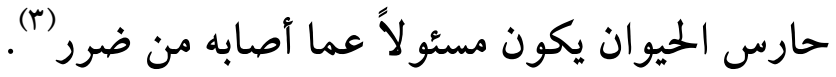
وغاية الأمر أنه في حالة وجود الاتصال المادي بين جسم الحيوان

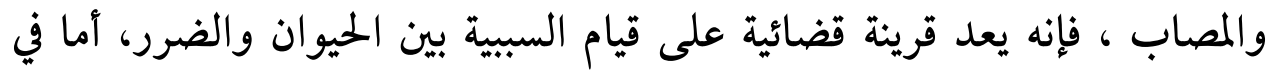

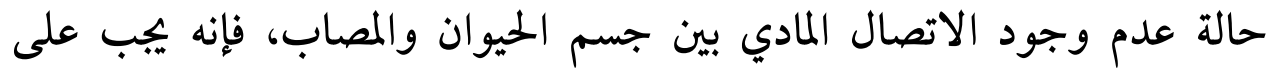

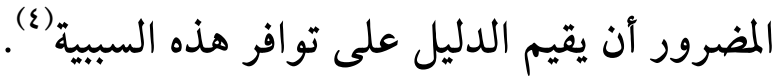

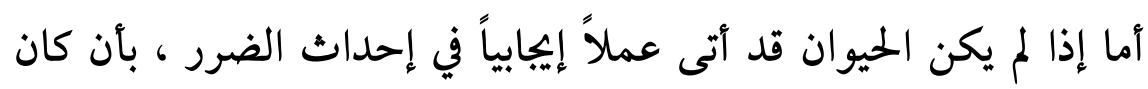

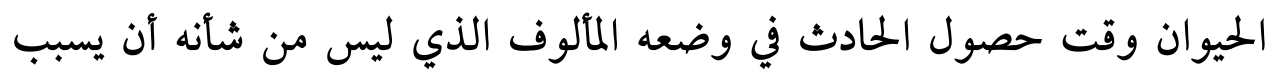

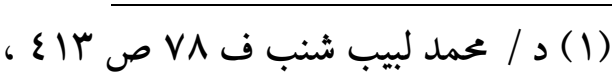

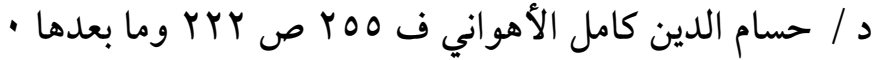

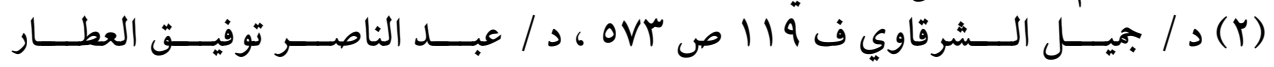

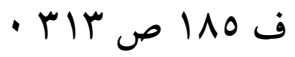

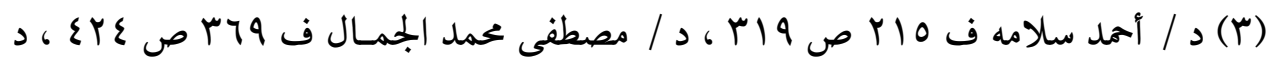

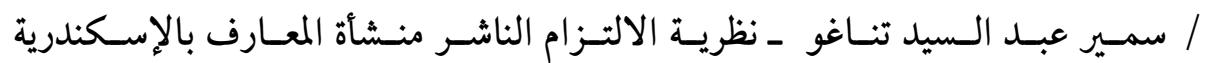

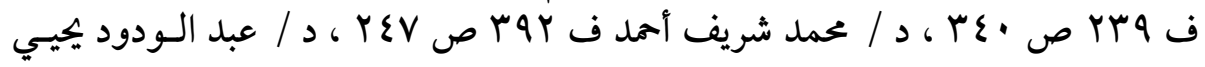

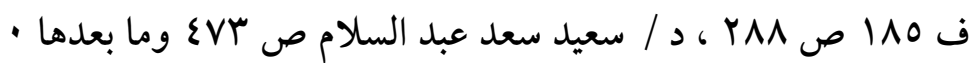

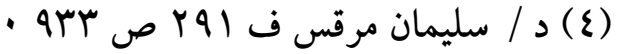


ضرراً في العادة (1) ، كما لو ارتطم شخص سائر بجيوان ثابت في مكانه وأصيب ،

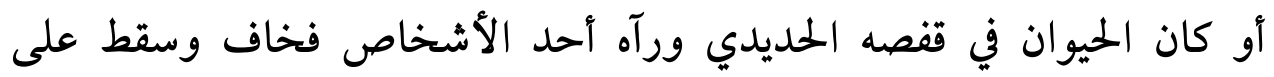

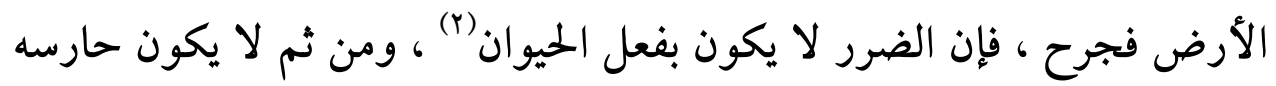

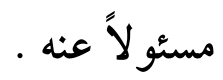
بيد أنه قد يحدث أحيانا أن يكون قد اشترك مع الحيوان عامل آخر في

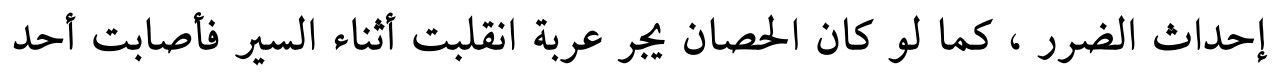

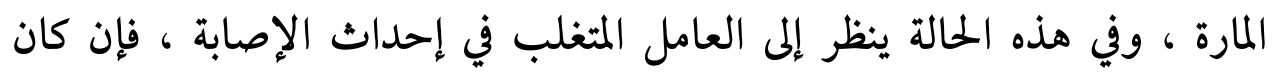

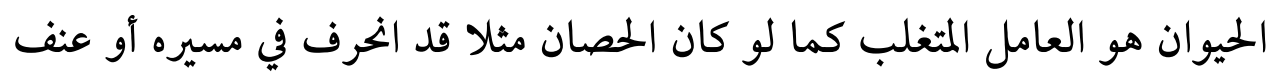
في جر العربة ، فإن الإصابة تعتبر من فعل الحيوان المانغان وإنما قد يدق تقدير ما إذا كان الضرر حدث بفعل الحيوان أم بفعل

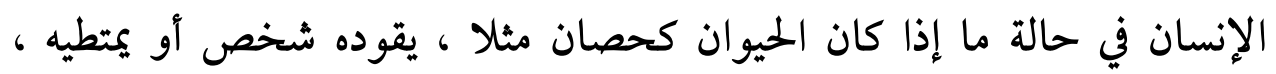

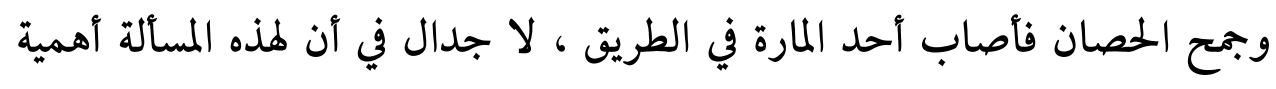

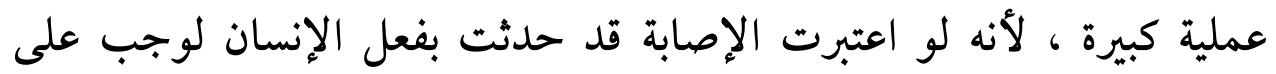

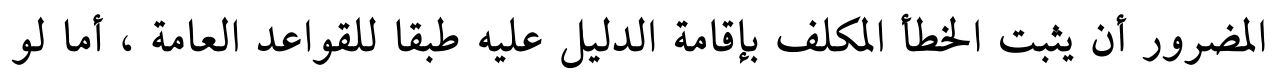

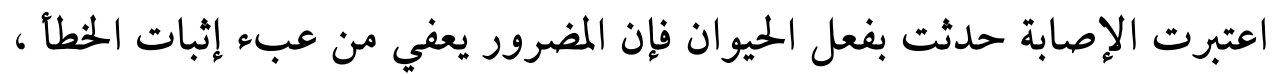

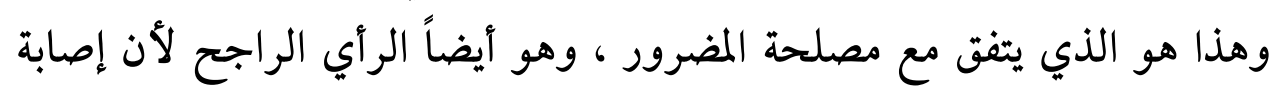

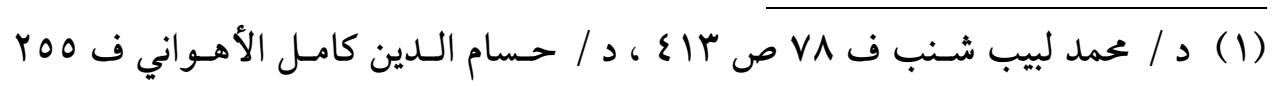

$$
\begin{aligned}
& \text { ص }
\end{aligned}
$$

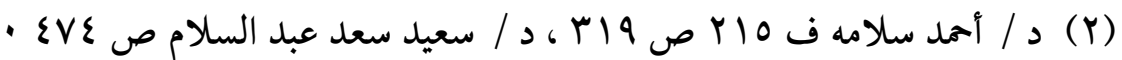

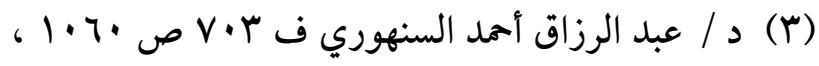

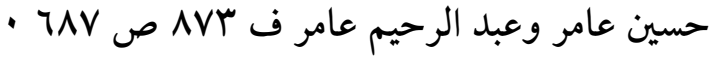


المضرور في مثل هذه الحالة لا تعتبر أنها قد حدثت بفعل الإنسان إلا إذا كان

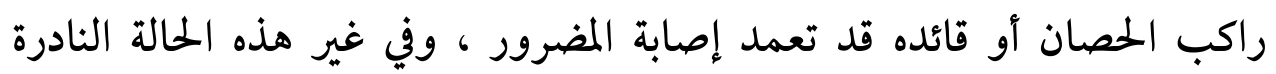

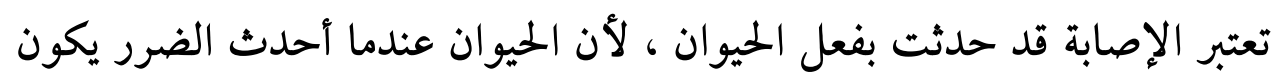

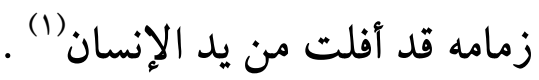

\section{ثانياً : أن ينتج ضرر هن الهيوان للغير :}

يلزم لتحقق مسئولية حارس الحيوان ، أن يكون هناك ضرر لحق الغير من جراء

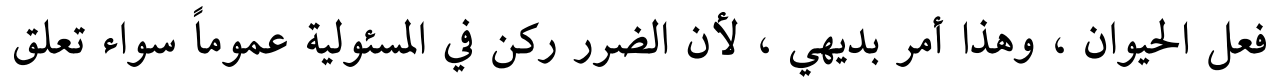

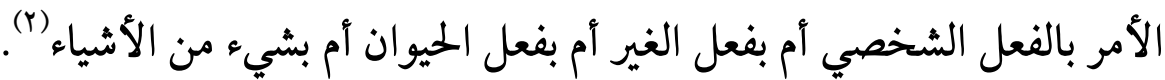
وأياً كان الضرر الذي أصاب المضرور ، فإن المسئولية عن فعل الحيوان تتحقق (r)،

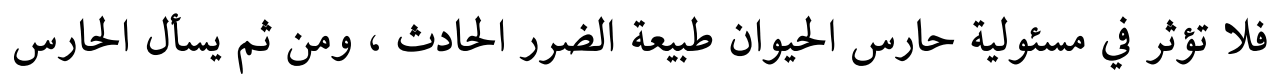

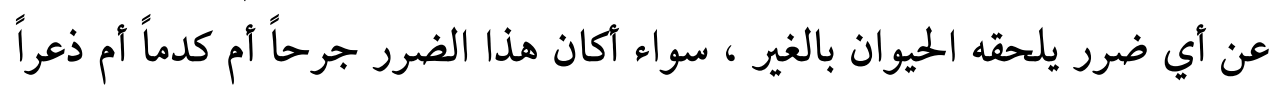

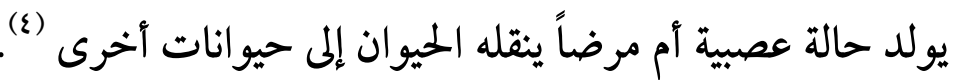

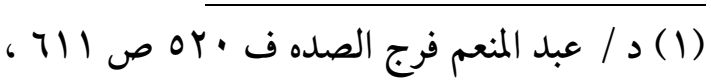

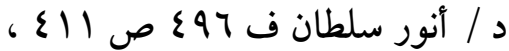

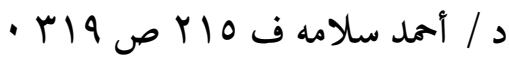

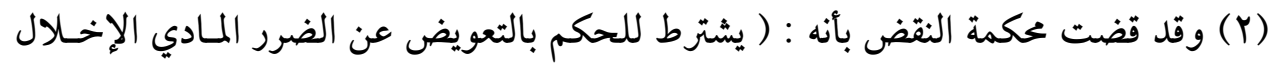

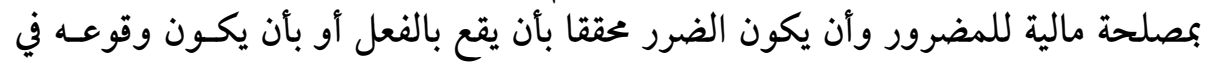

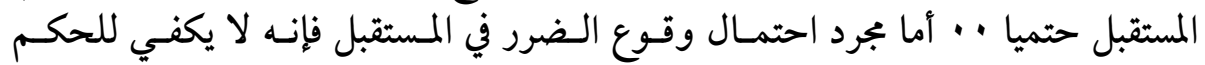
بالتعويض )

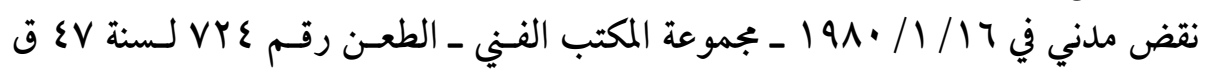

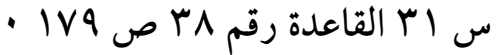

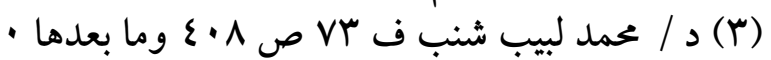

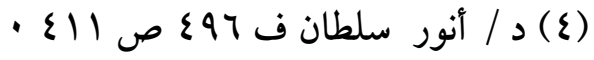




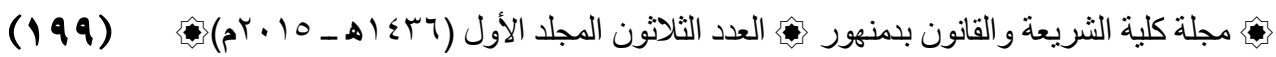

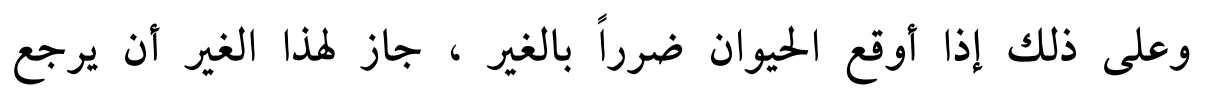

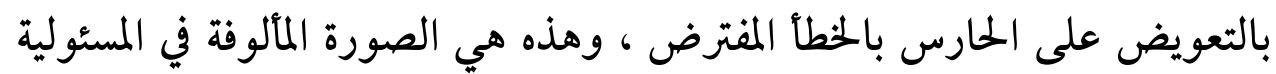
عن فعل الحيوان (1). ولكن تدق المسألة إذا كان المضرور هو الحارس نفسه ، أو المالك غير

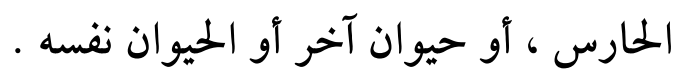
وأبين ذلك فيما يلي :

1 ـ إذا أحدث الحيوان ضرراً بالحارس نفسه ، وكان الحارس شخصاً غير المالك ،

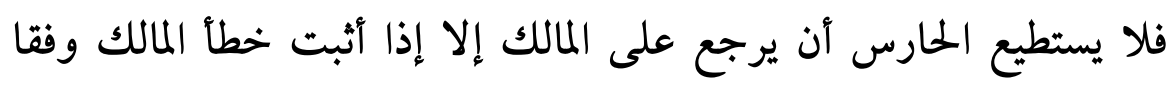

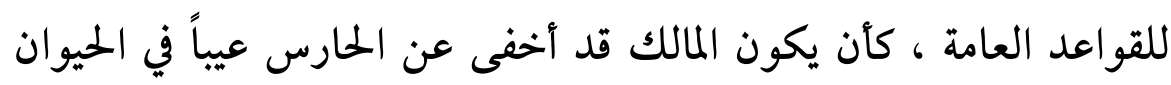

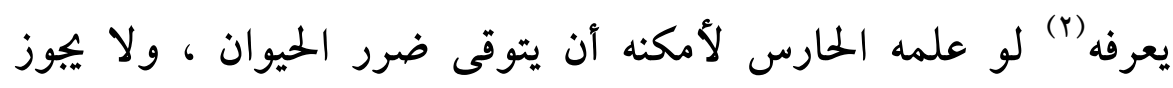

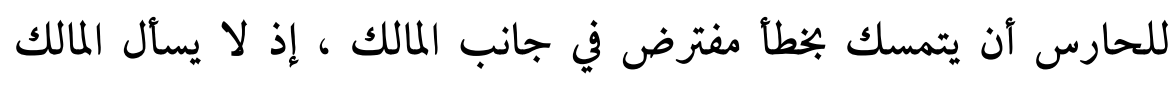

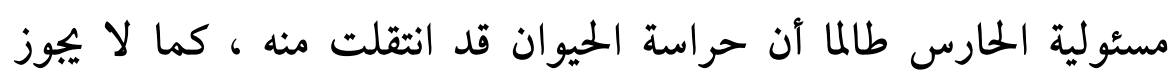

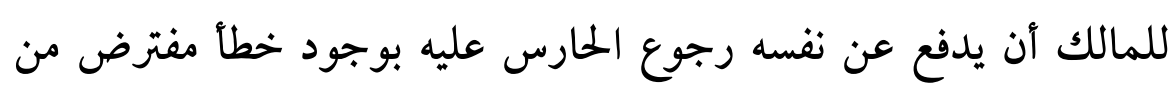

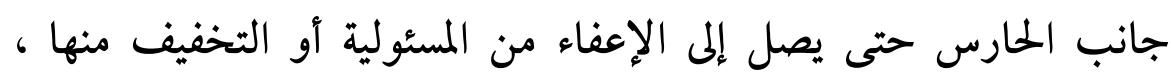

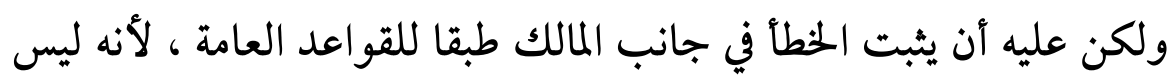

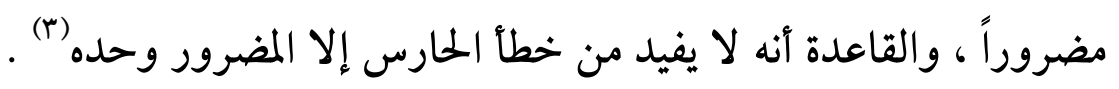

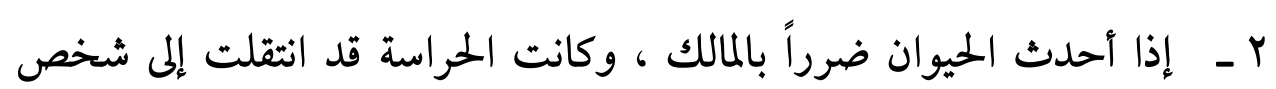

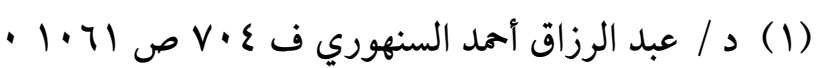

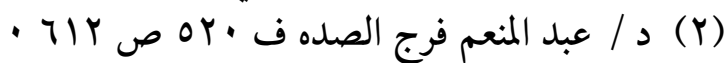

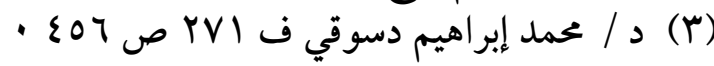


$(Y+$.

المسئولية عن فعل الحيوان "دراسة مقارنة بالفقه الإسلامي"

آخر غيره ، فللمالك أن يرجع على الحارس بالتعويض وفقا لأحكام

المسئولية المفترضة عن فعل الحيوان ، لأن المالك يعتبر غيراً في هذه الحالة (1).

بيد أنه يشترط في تطبيق هذه المسئولية المفترضة ألا يكون المصاب قد تسبب

بخطئه في وقوع الضرر الذي أصابه بفعل الحيوان وإلا فإنه يجب عليه في

مطالبة حارس الحيوان بالتعويض أن يثبت وقوع خطاً من الحارس وفقا

للقواعد العامة) مطالبه

بـ ـ إذا أحدث الحيوان ضرراً بنفسه ، كما لو دار فالتف الحبل المربوط به على

رقبته فاختنق ، فهنا يفرق بين ما إذا كان الحارس هو المالك وبين ما إذا كان

الحارس غير المالك ، فإذا كان الحارس هو المالك ، هلك الحيوان على

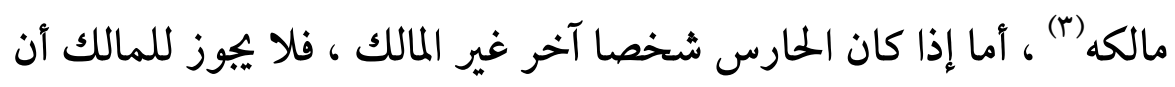

يرجع على الحارس بتعويض الضرر الذي أصاب الحيوان على أساس المادة

IVT مدني ، وسبب ذلك يعود إلى أن هذه المادة تستهدف كفالة تعويض لحسي

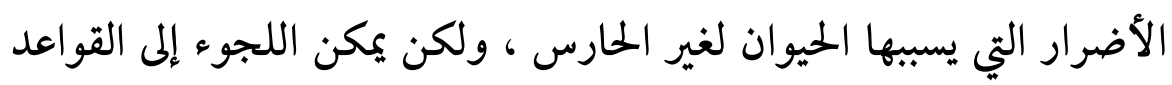

العامة في المسئولية(ع) حتى يحصل منه على تعويض. يسئ.

بيد أنه إذا كان الحارس قد تولى حراسة الحيوان وفقا لعلاقة عقدية بينه

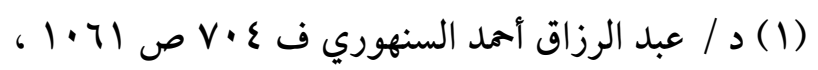

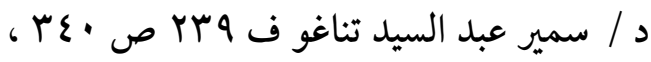

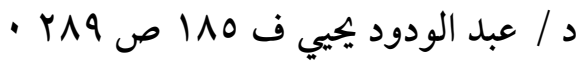

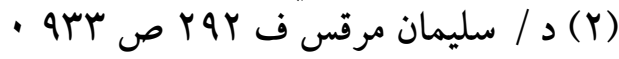

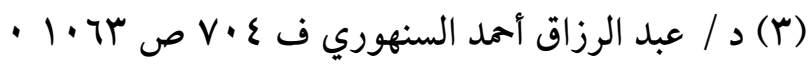

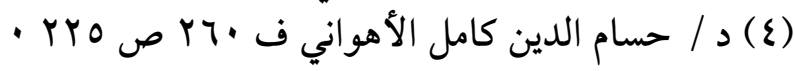




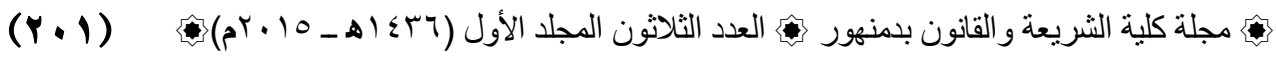

وبين المالك ، فإن أحكام العقد هي التي تحدد الجزاء الذي يوقع على الذى

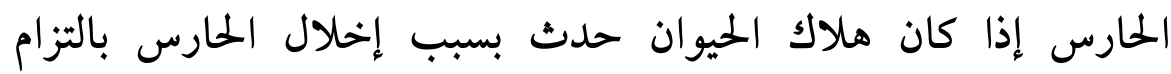

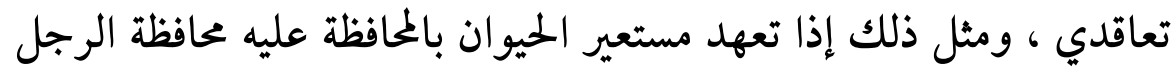

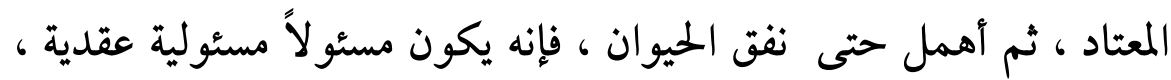

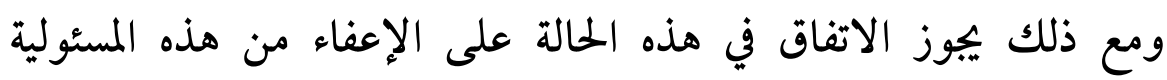

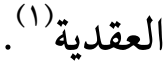

ع - إذا وقع الضرر من الحيوان على حيوان آخر ، وكان كل حيوان قد تدخل

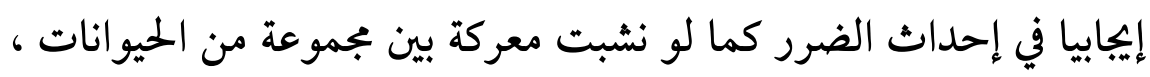

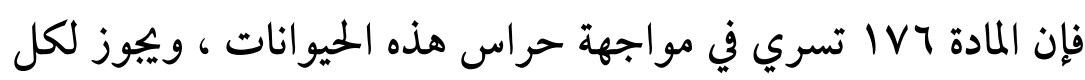

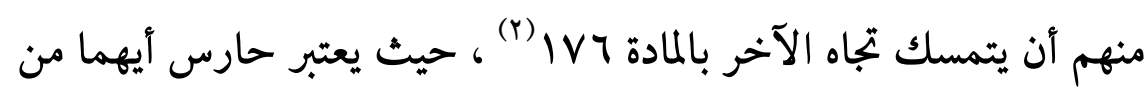

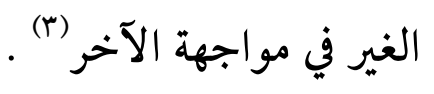

0 - إذا أوقع الحيوان ضرراً بتابع المالك كسائقه أو سائسه ، جاز للتابع أن

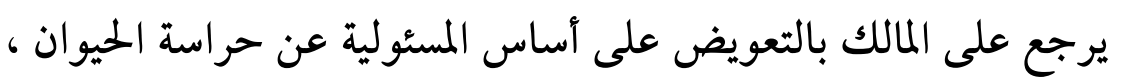

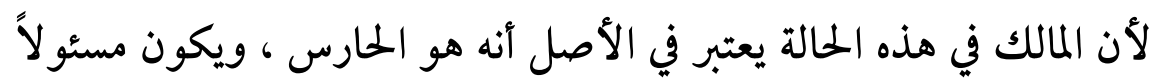

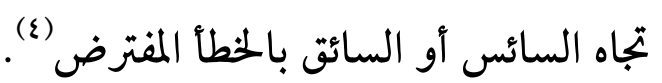

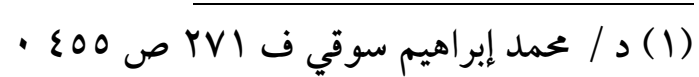

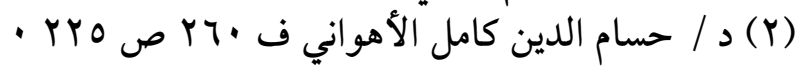

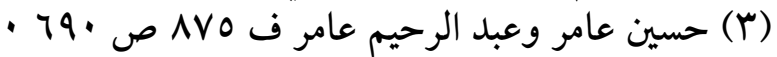

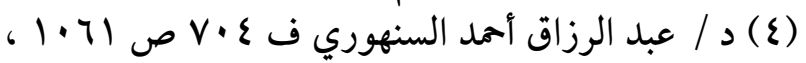

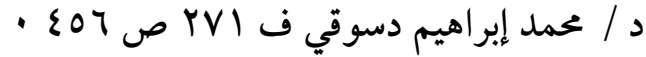




\section{المطلب الثاني \\ شروط ضمان فعل الحيوان في الفقه الإسلامي}

يشترط لضمان فعل الحيوان في الفقه الإسلامي ، أن يكون الحيوان بيد شـحص

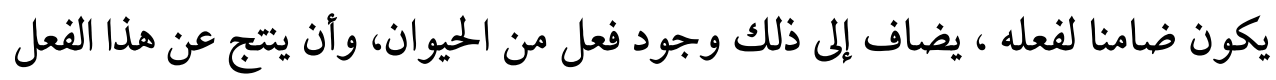
ضرر بالغير.

وقد سبق الحديث عن الشرط الأول عند تحديد الضامن لفعل الحيوان ، وأتكلم

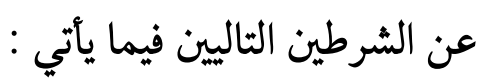

أولاً : وجود فعل هن الهيوان :

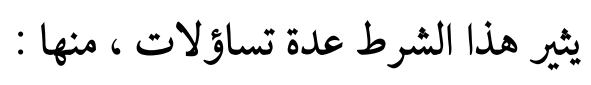

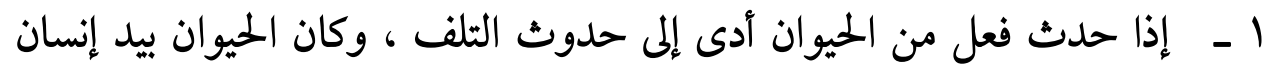

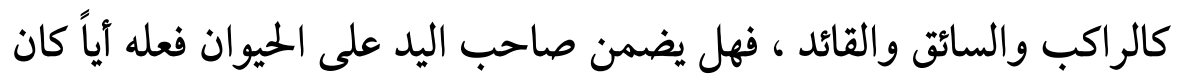

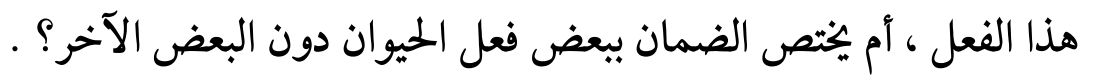

r - إذا نزلت المواشي زراعة شخص فأتلفتها بدون تدخل من صاحب اليد عليها ،

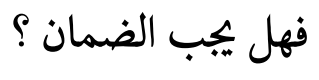

بـ ـ ما حكم إتلاف الحيوان الخطر للمال أو النفس ؟ .

ع - هل يجب الضمان إذا كان الحيوان في وضعه المألوف كما لو كان مربوطاً أو

$$
\text { موقوفاً ؟ مل }
$$

وبإذن الله سأجيب عن هذه التساؤلات في مسائل اذكرها على النحو التالي : 


\section{المسألة الأولى : نوع الفعل الذي يضهنه صاحب اليد على الحيوان :}

اختلف الفقهاء في نوع الفعل الذي يضمنه صاحب اليد على الحيوان ، سواء أكان

راكبا آم سائقا أم قائداً ، على أربعة أقوال :

القول الأول : ذهب المالكية(1) والحنابلة(r) في صحيح المذهب إلى أن صاحب اليد المبال

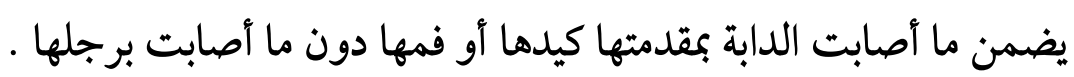

بيد أن عدم الضمان فيما أصابت الدابة برجلها مقيد بأن لا يفعل صاحب

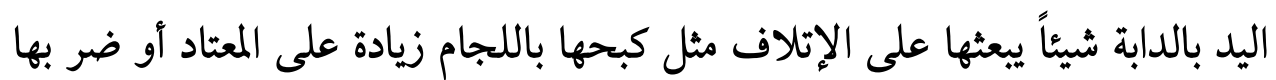
في الوجه ، ونحو ذلك ، فإن فعل ضمن جناية رجلها أيضاً (r). أدلة مذا القول : استدل أصحاب هذا القول بالسنة والمعقول .

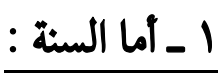

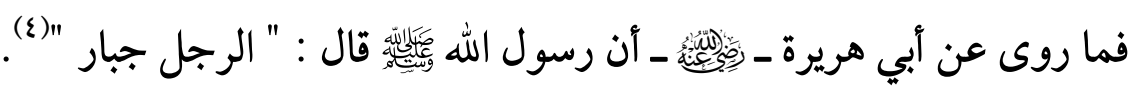

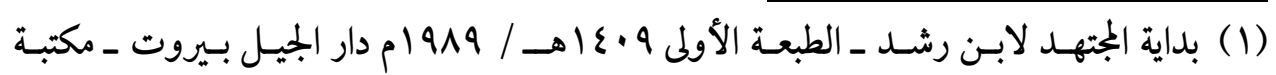

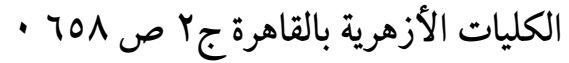

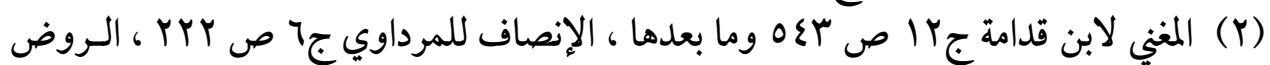

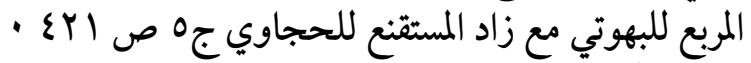

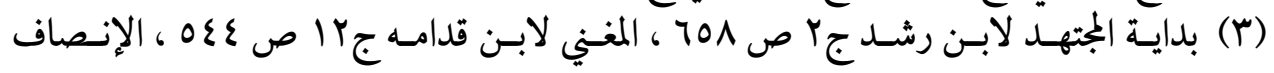

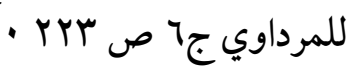

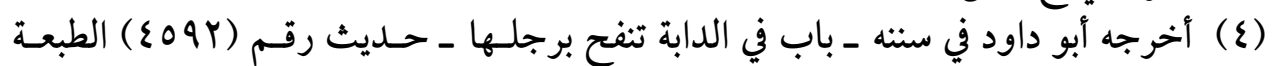

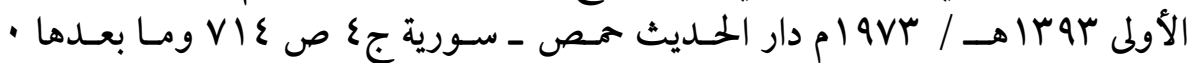

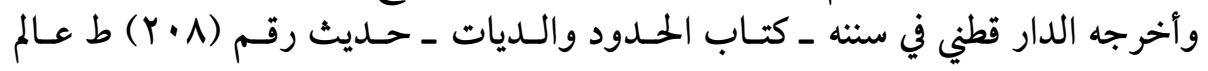

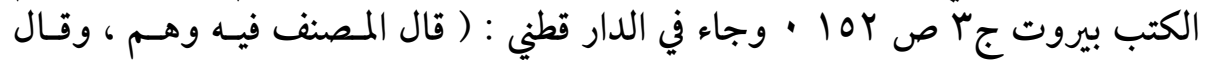

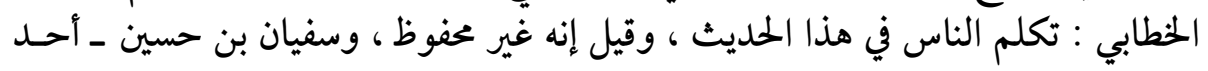




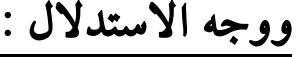

أن تخصيص الرجل بكونه جباراً أي هدراً ، دليل على وجوب الضمان في

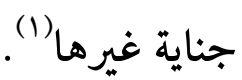

$$
\text { r - وأما المعقول : ب }
$$

فهو أنه لا ضمان فيما جنت الدابة برجلها ، لأن الراكب أو القائد أو السائق

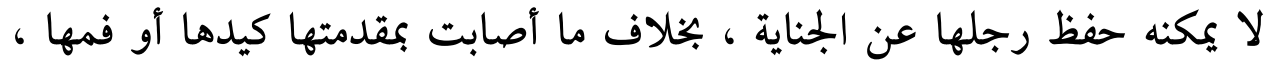

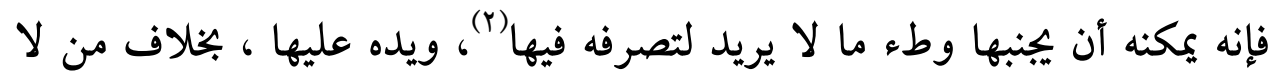

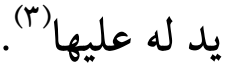

القول الثاني : ذهب الحنفية() والحنابلة (o) في رواية إلى أن صاحب اليد يضمن ما وطئت الدابة وما أصابت بيدها أو رجلها أو رأسها أو كدمت " أي عضت بـت بفمها

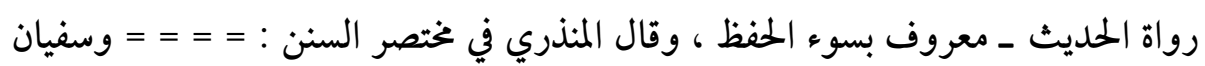

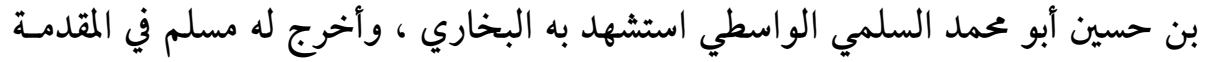

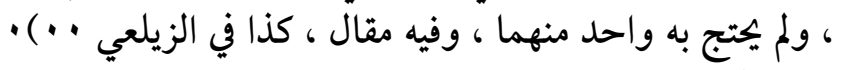

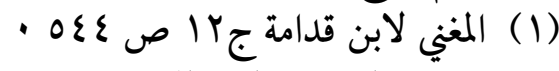

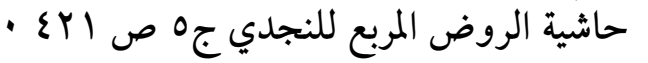

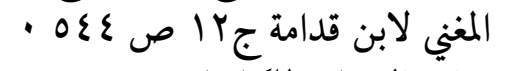

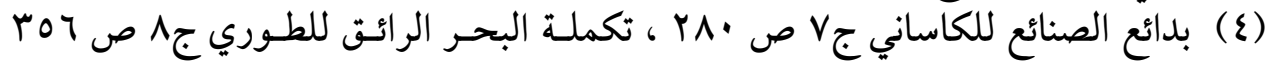

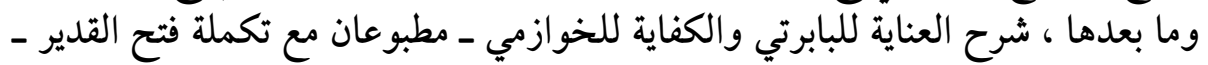

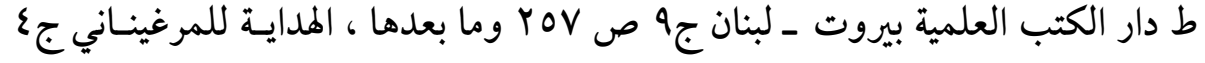

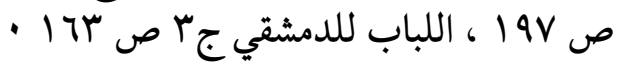

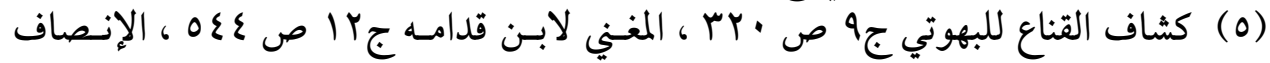

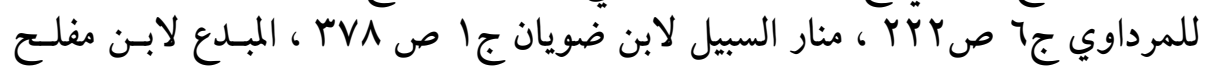

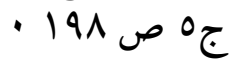




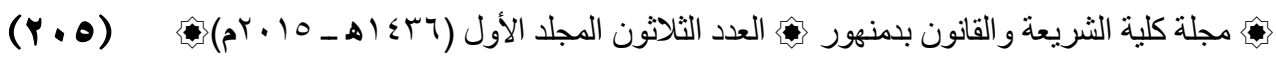

" أو خبطت " أي ضربت بيدها " أو صدمت بجسدها، ولا يضمن ما نفحت " أي ضربت برجلها أو ذنبها " . بيد أن الحنفية قصروه على ما إذا كان الراكب أو القائد أو السائق يسير في

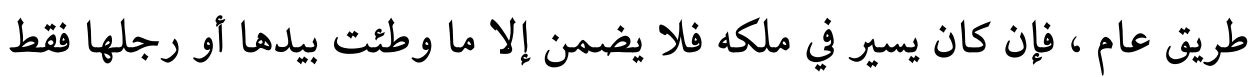

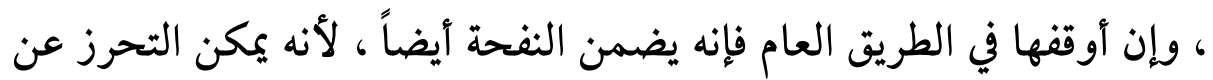
الإيقاف وإن لم يمكنه عن النفحة . أدلة هذا القول : استدل أصحاب هذا القول بالسنة والمعقول.

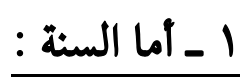

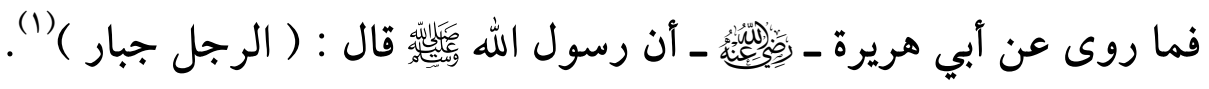

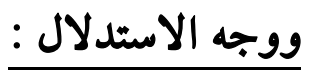

أن تخصيص الرجل بكونه جباراً ، دليل على وجوب الضمان في جناية

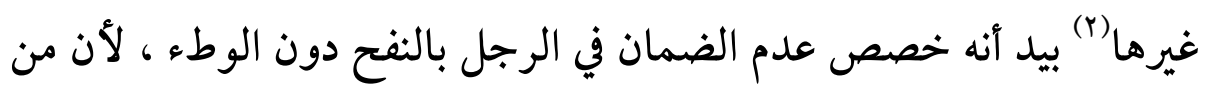

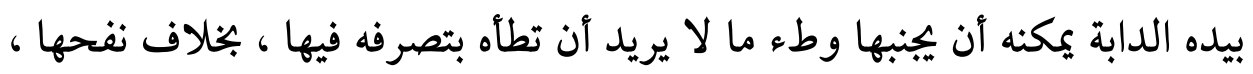
فإنه لا يمكنه أن يمنعها منه (r). Y - وأما المعقول :

فهو أن المرور في طريق المسلمين مباح ، لكنه مقيد بشرط السلامة فيما يكنه

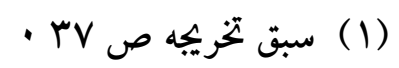

.

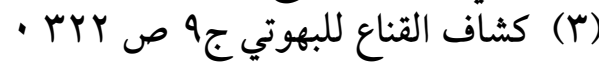


الاحتراز عنه ، دون ما لا يمكن ، لما فيه من المنع في التصرف ، وسد بابه ،

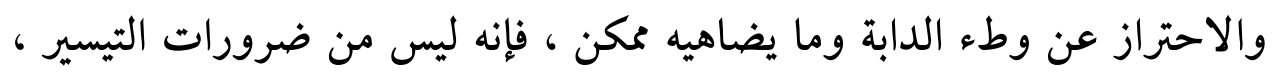

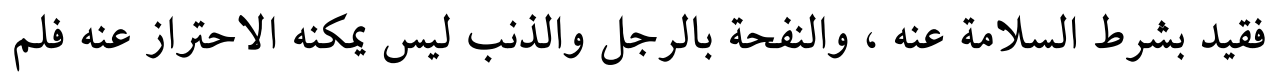
يتقيد به (1).

القول الثالث : ذهب الشافعية(r) إلى أن صاحب اليد يضمن ما تتلفه البهائم

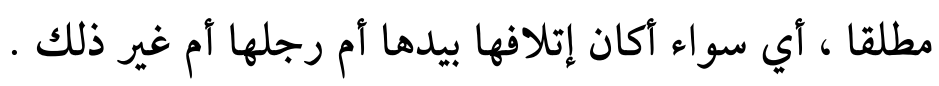
دليل مذا القول : استدل الشافعية لقولمم بالمعقول : وهو أن الدابة في يد صاحب اليد وعليه

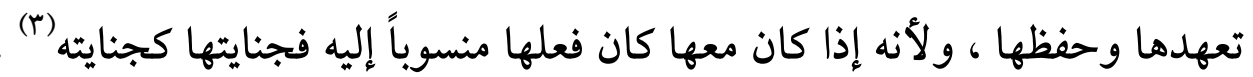
القول الرابع : ذهب الظاهرية() إلى عدم ضمان صاحب اليد ما تتلفه البهائم مطلقاً . أدلة مذا القول : استدل الظاهرية لقولهم بالسنة والمعقول .

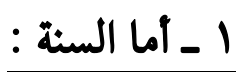

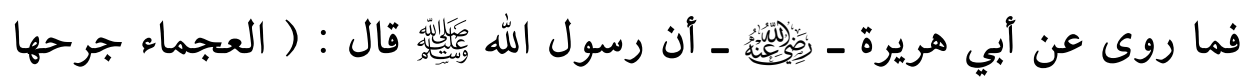

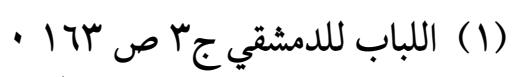

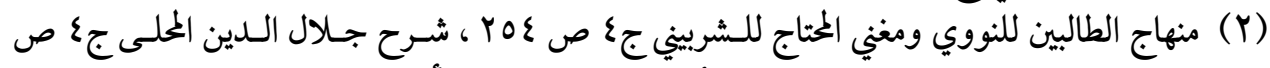

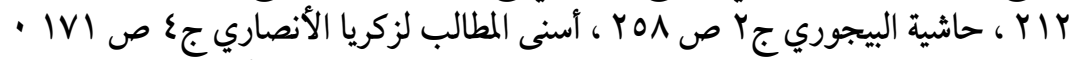

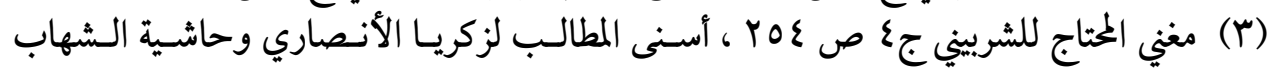

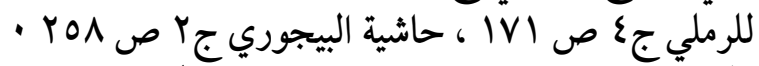

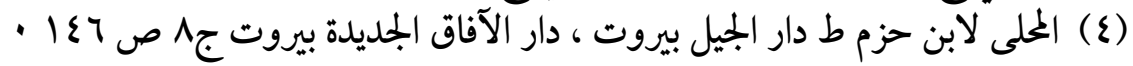




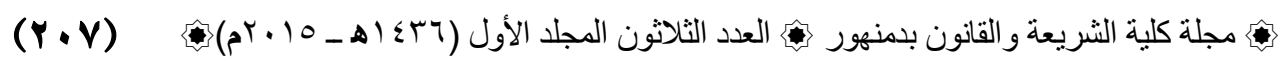

جبار (1) ( )

ووجه الاستدلال : أن المراد بالجبار المدر الذي لا شيء فيه (r) ، ومن ثم فيسقط الضمان عن صاحب اليد على الحيوان .

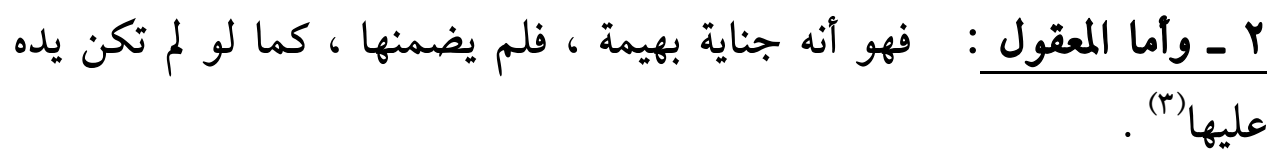

\section{هناقشة وترجيح :}

ناقش أصحاب القول الثاني ما استدل به أصحاب القول الأول على أن

صاحب على الحيوان يضمن ما أصابت الدابة بمقدمتها دون ما أصابت برجلها ، بأن عدم الضمان في الرجل خختص بالنفح لأنه لا يمكنه أن يمنعها منه بخلاف ما وطئت الدابة برجلها ، فيسري عليه الضمان ، لأنه يمكنه أن يجنبها وطء ما لا

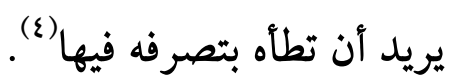

كما ناقش أصحاب القول الثاني ما استدل به أصحاب القول الرابع على عدم

ضمان صاحب اليد ما تتلفه البهائم مطلقا ، بأن حديث ( العجماء جرحها جبار )

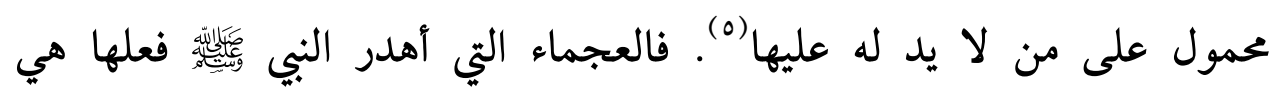

المنفلتة (7)

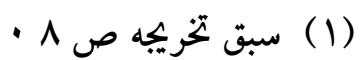

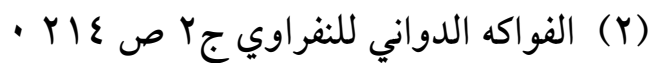

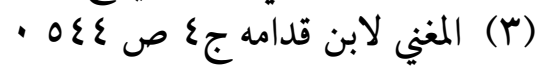

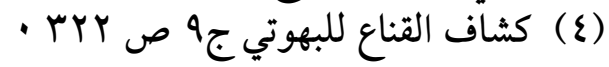

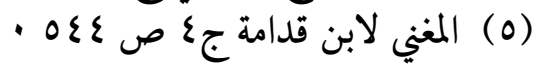

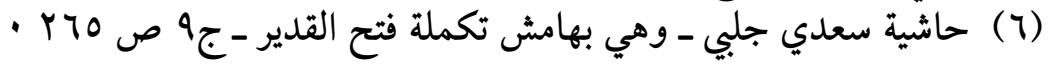


وبذلك يتضح أن الراجح في تقديري هو ما ذهب إليه أصحاب القول

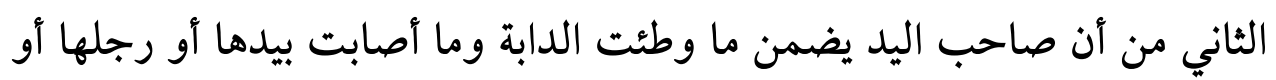

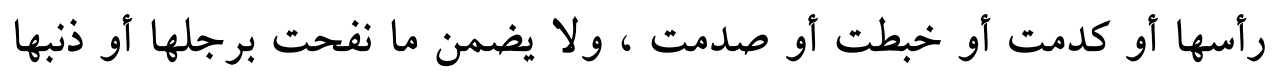

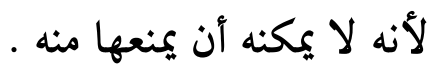

\section{المسألة الثانية : إتلاف المواشي زراعة الغير :}

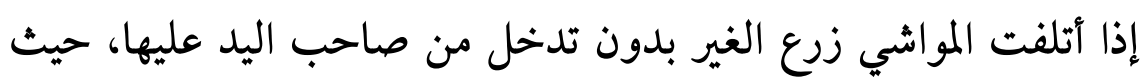

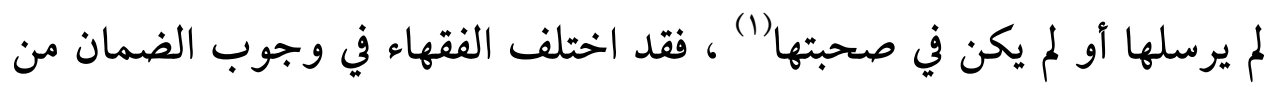
عدمه على قولين :

القول الأول : ذهب الحنفية(r) والظاهرية(r) إلى عدم وجوب الضمان ، سواء أكان

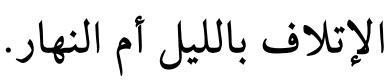

أدلة مذا القول : استدل أصحاب هذا القول بالسنة والمعقول .

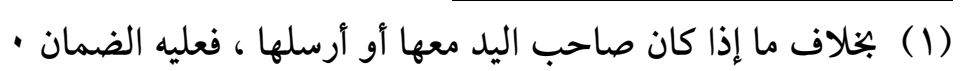

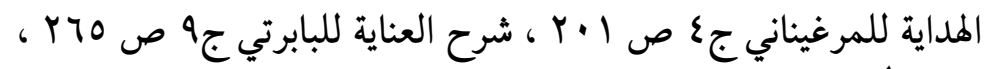

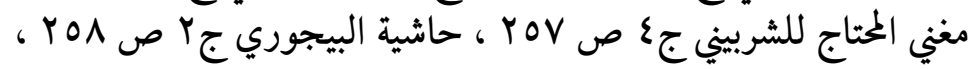

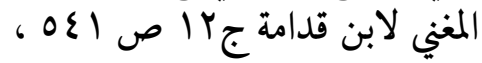

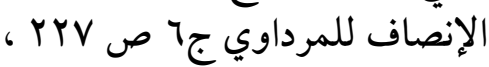

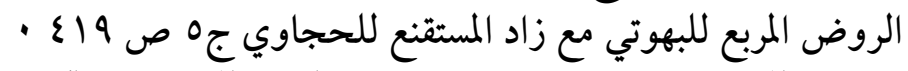

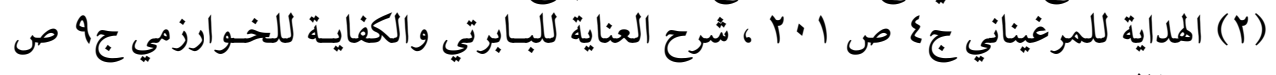

- rTo

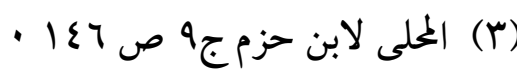




\section{1 ـ أما السنة :}

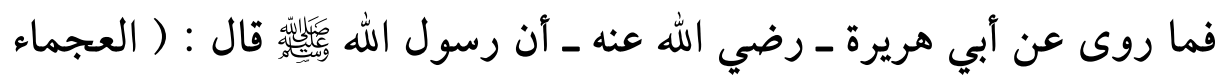

\section{جرحها جبار (') أن

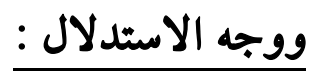

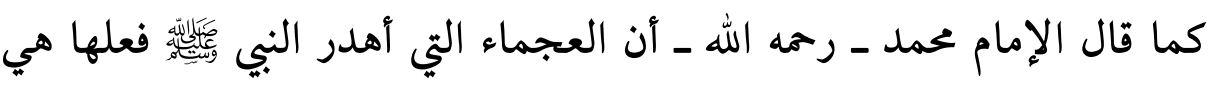

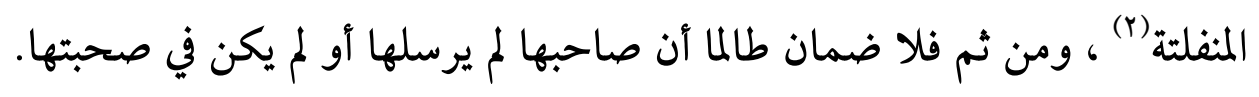
r ـ ـ وأما المعقول

فهو أن الفعل غير مضاف إلى صاحب اليد لعدم ما يوجب النسبة إليه من

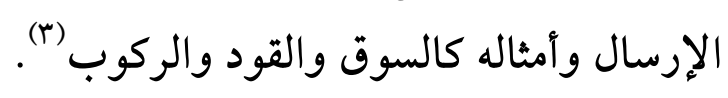

القول الثاني : ذهب جمهور الفقهاء ( المالكية(ع) والشافعية(0) والحنابلة(1) ) إلى إلى عدم ضمان ما أتلفت المو اشي نهاراً وضمانها ليلاً.

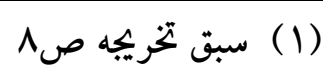

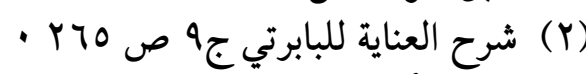

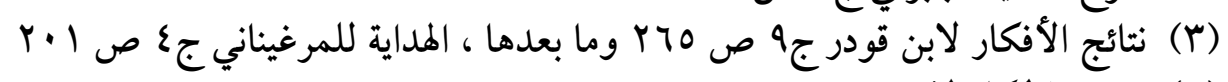

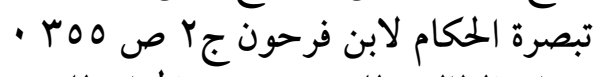

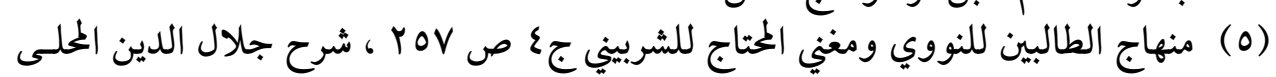

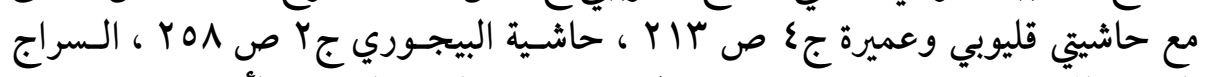

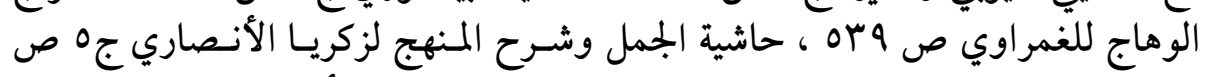

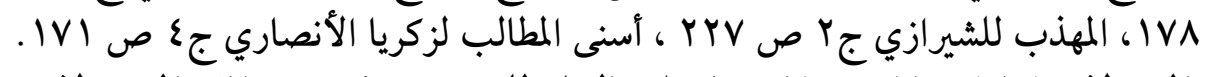

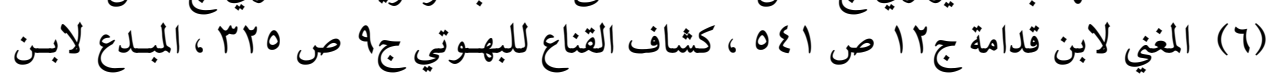

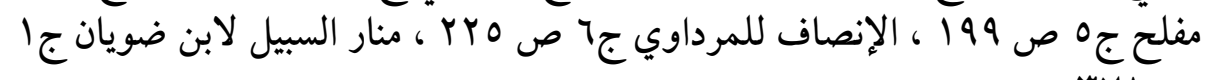
- ص ص 
أدلة مذا القول : استدل أصحاب هذا القول بالكتاب والسنة والمعقول. ـ أما الكتاب :

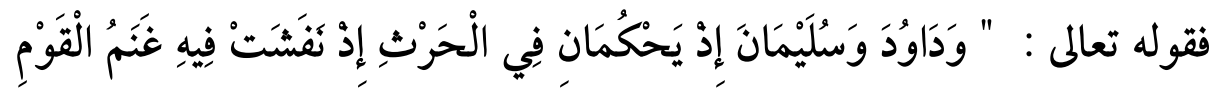

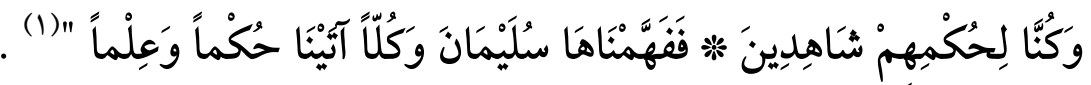

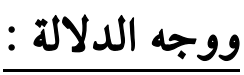

المراد بالنفش : أن الغنم انتشرت بالليل من غير راع وأكلت الزرع (r)، وإذا

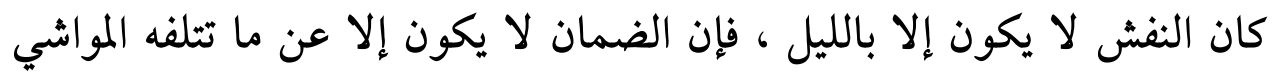
بالليل.

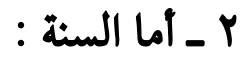

فهو حديث حرام بن سعيد بن محيصة : " أن ناقة للبراء دخلت حائط قوم فأفسدت فيه ، فقضي رسول الله

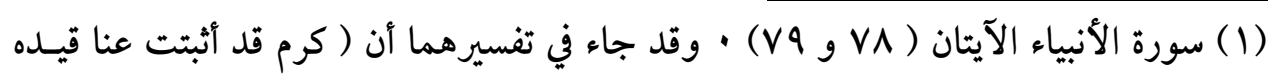

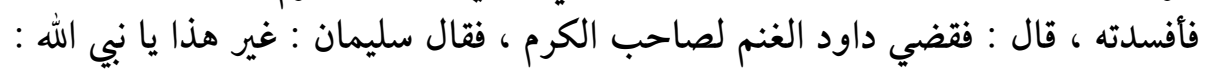

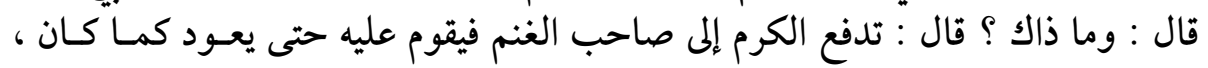

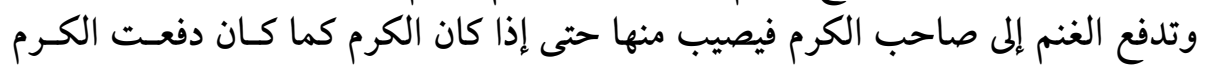

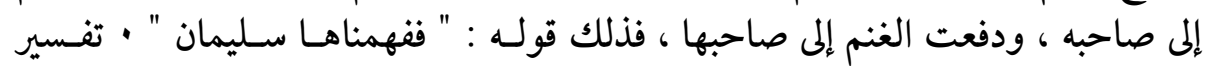

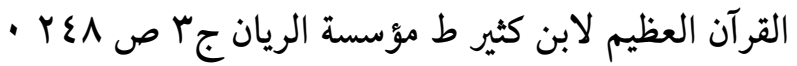

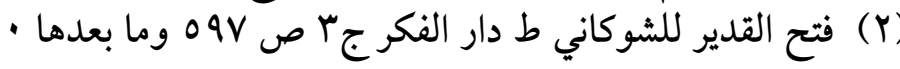


$(Y \mid 1)$

أفسدت المواشي بالليل فهو ضامن على أهلها )(") ووجه الاستدلال : - n

أن رسول الله

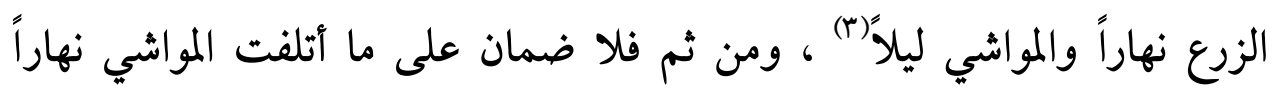
وضمانها ليلاً.

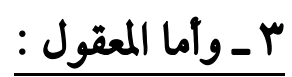

فهو أن العادة من أهل المواشي إرسالها نهاراً للرعي ، وحفظها ليلاً ، وعادة أهل

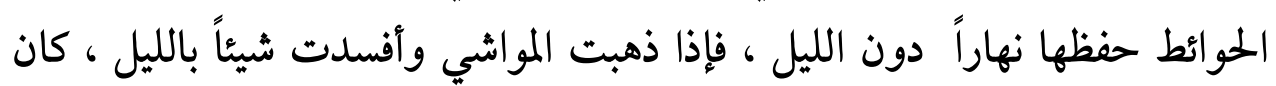

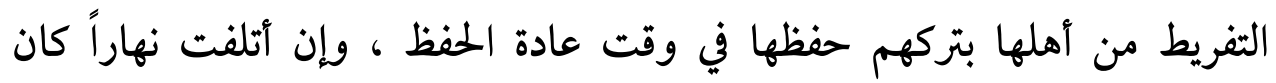

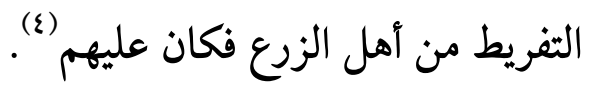

القول الراجح :

وفي تقديري أن القول الراجح هو ما ذهب إليه أصحاب القول الثاني من

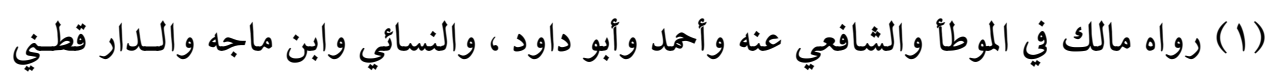

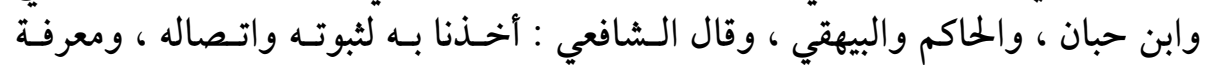

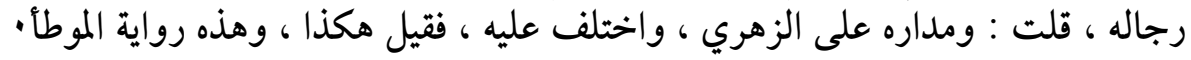

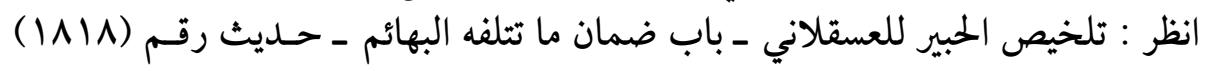

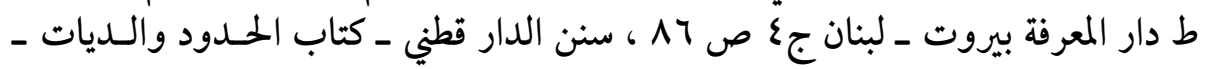

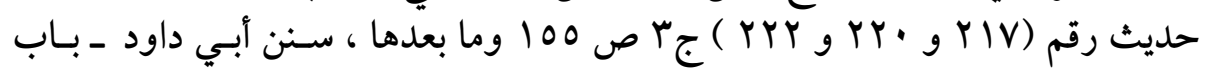

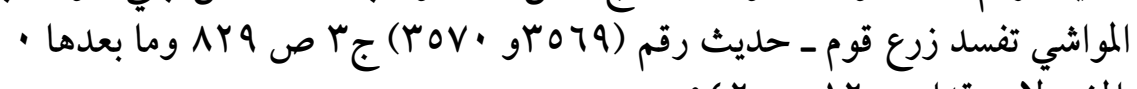

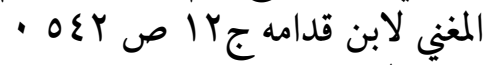

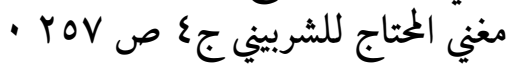

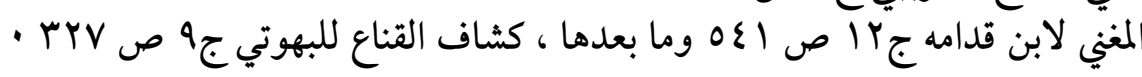


عدم ضمان ما أتلفت المواشي نهاراً وضمانها ليلاً لقوة الأدلة التي استندوا إليها من القرآن الكريم والحديث الصحيح الذي هو على وفق العادة في حفظ الزرع ونهوه

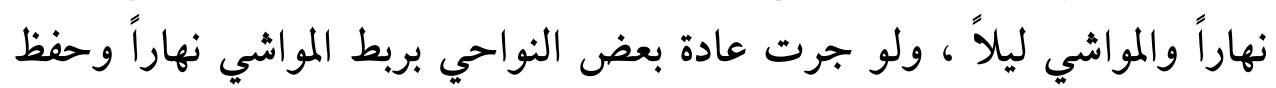

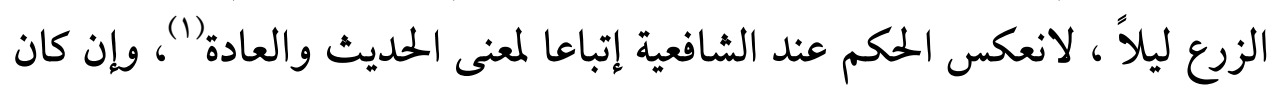

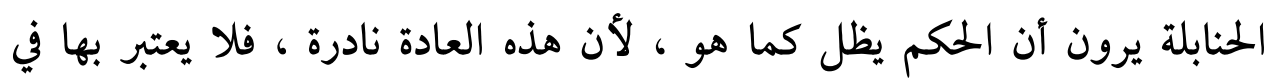

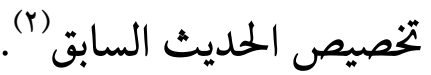

\section{المسألة الثالثة : إتلاف الحيوان الخطر للهال أو النفس}

إذا أتلف الحيوان الخطر مالاً أو نفساً ، فإنه يفرق بين ما إذا كان الحيوان

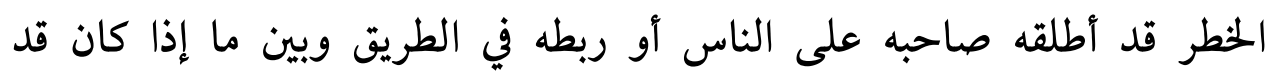

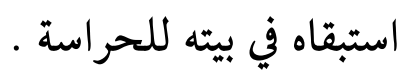

فإذا كان الحيوان خطراً كالكلب العقور والدابة الرفوس أو العضوض ، وكذا

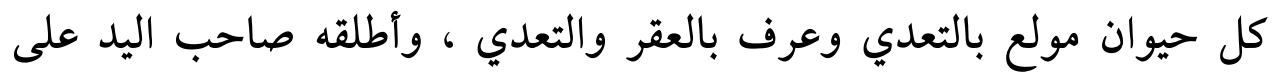

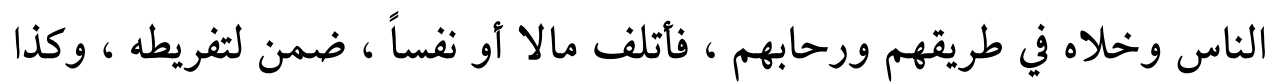
إن كان له طائر جارح كالصقر والبازي ، فأفسد طيور الناس ورحان ، وحيواناتهم ، ضمن

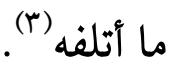

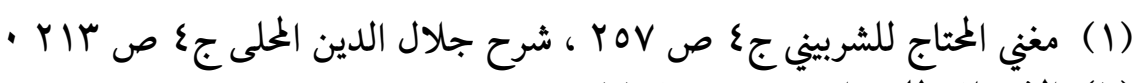

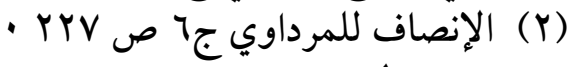

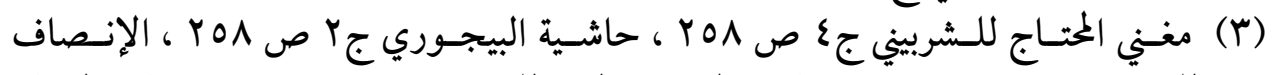

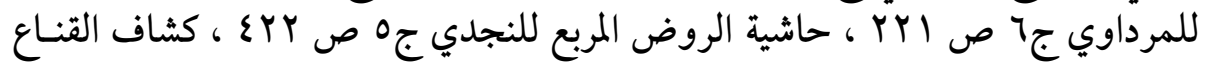




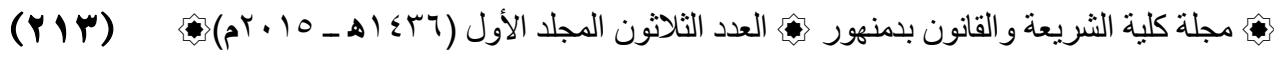

خاصة إذا تقدم لصاحب اليد على الحيوان واحد من أهل محلته أو قريته

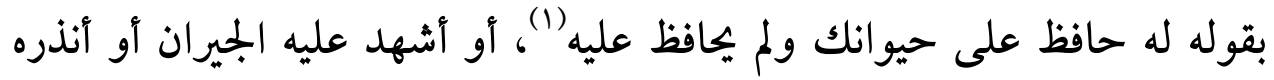
عند الحاكم (r) بقوله

وكذلك إذا ربط صاحب اليد بالطريق دابة تعض أو ترفس من يمر

بالطريق ، فإنه يضمن ما تتلفه (r) إدب

أما إذا كان صاحب اليد ، قد استبقى الحيوان الخطر في بيته للحراسة كما

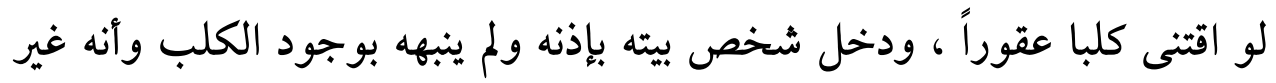

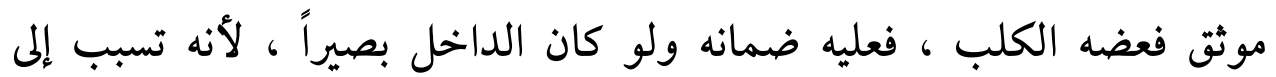

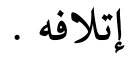

أما إن دخل شخص بيته بلا إذنه ، أو نبهه بوجود الكلب وأنه غير موثق،

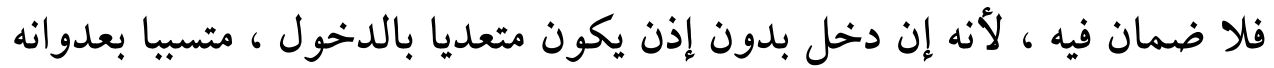

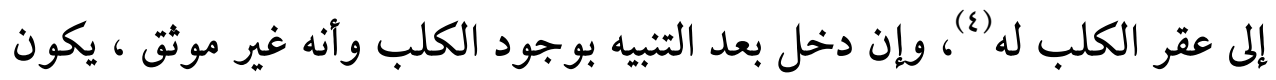

(1) شرح المجلة لسليم رستم باز اللبناني ـ الطبعة الثالثة دار الكتـب العلميـة بـيروت ـ لبنـان

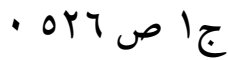

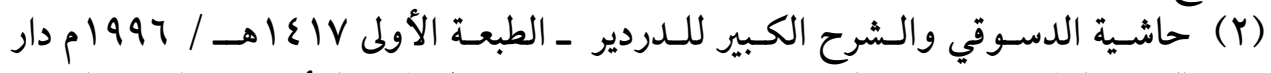

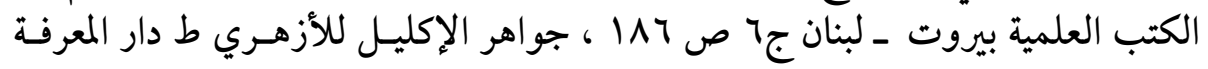

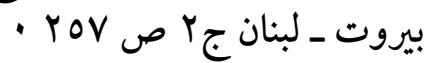

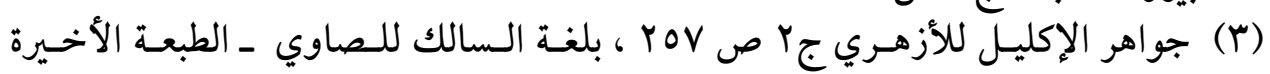

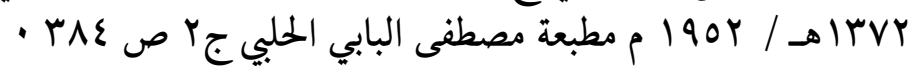

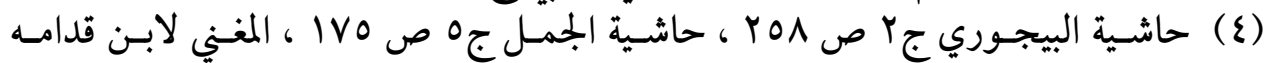

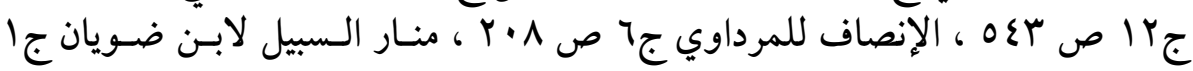
- rVA ص D 
دخل على بصيرة وعلم ، فإصابته تكون ناتجة عن إهماله وترك الحيطة والحذر ،

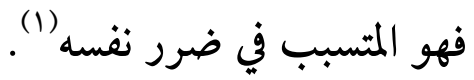

\section{المسألة الرابعة : الإتلاف الحاصل هن الحيوان المربوط أو الموقوف:}

إذا أوقف صاحب اليد الحيوان في المكان الذي توقف فيه الدواب، أو ربطه في المكان المعد لذلك ، أو المأذون فيه شرعا كسوق الخيل ونحوه، ولم يكن الحيوان معروفا بالعداء وحصل الإتلاف منه لغير شيء فعل به فلا ضمان على صاحب

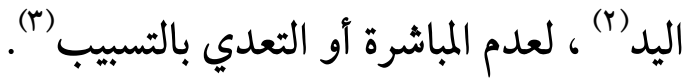

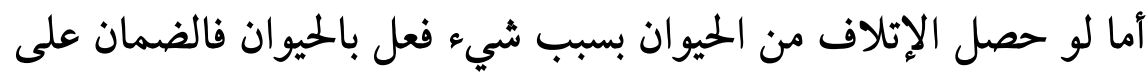

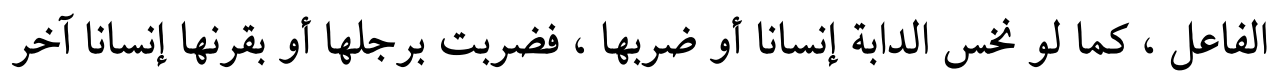

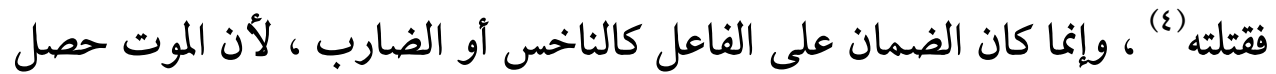

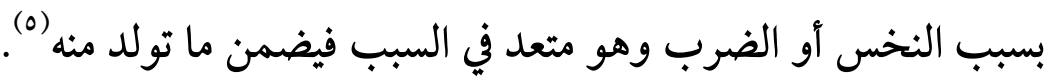

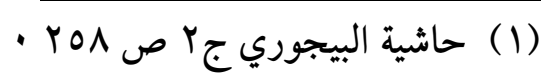

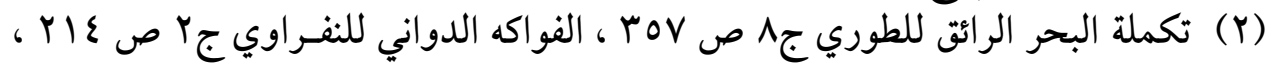

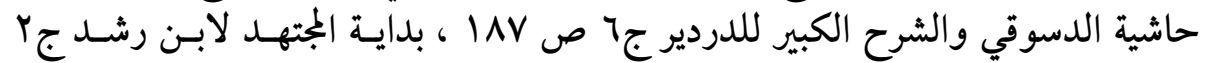

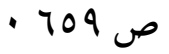

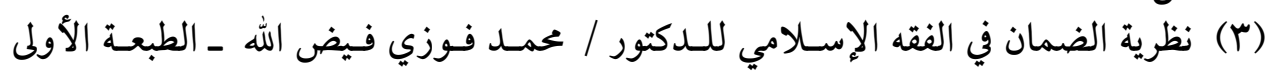

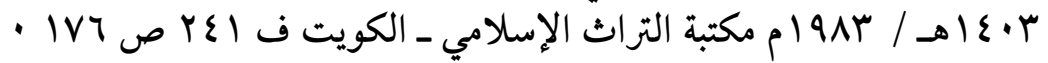

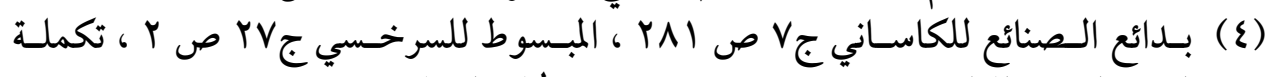

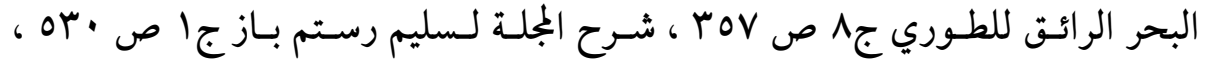

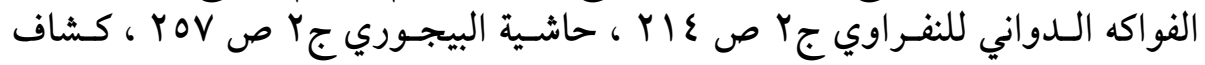

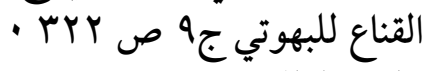

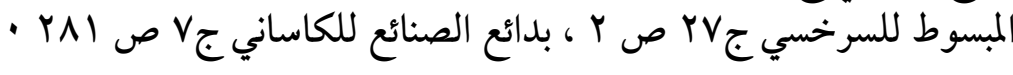




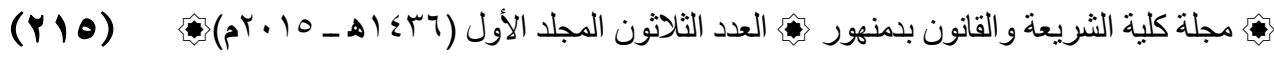

أما لو أوقف أو ربط صاحب اليد الحيوان في غير المكان المعد لوقوف

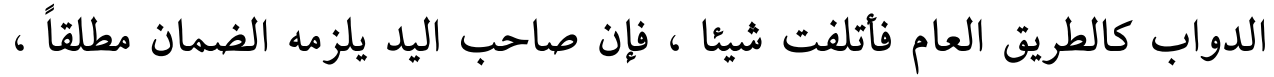
لأنه بالإيقاف متسبب متعد إذ ليس له شغل طريق المسلمين بإيقاف الحيوان فيه ، ولأن الانتفاع بالطريق مشروط بسلامة العاقبة (1). وفرق الحنابلة(r) بين ما إذا أوقف الحيوان في طريق ضيق أو أوقفه في

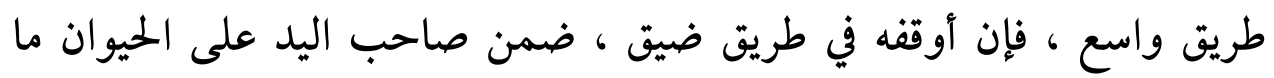

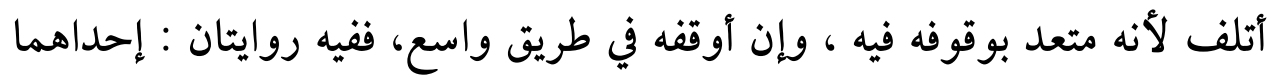

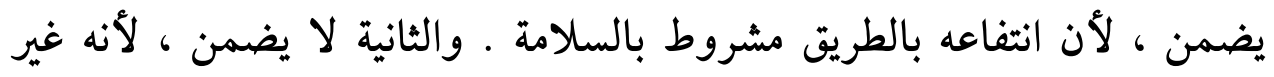

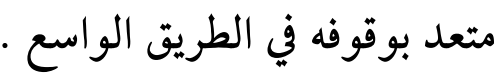

\section{ثانيًا : أن ينتج ضرر هن الحيوان للغير :}

يشترط لضمان صاحب اليد على الحيوان ، أن يكون فعل الحيوان قد نتج

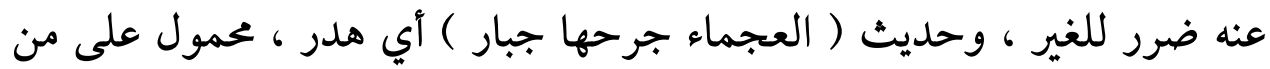

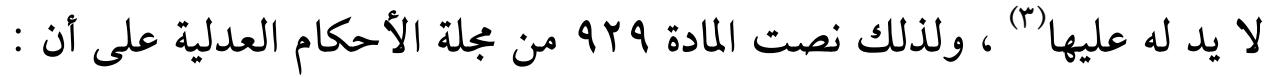
( الضرر الذي أحدثه الحيوان من تلقاء نفسه لا يضمنه صاحبه).

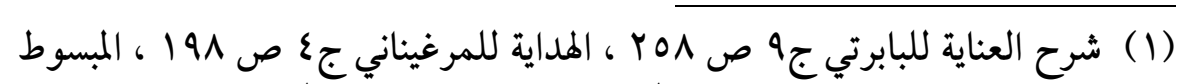

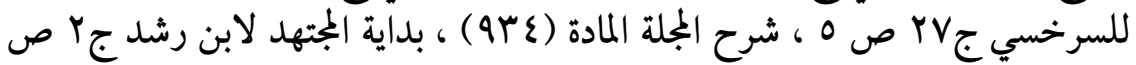

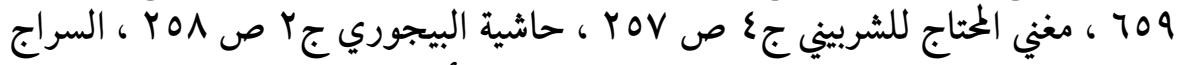

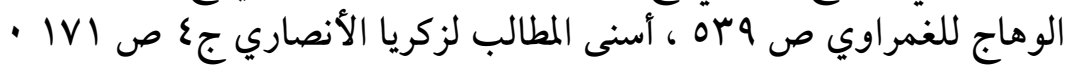

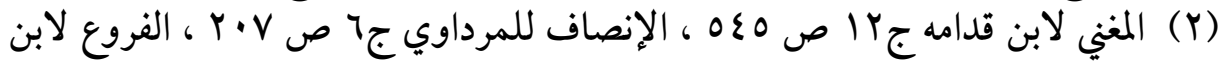

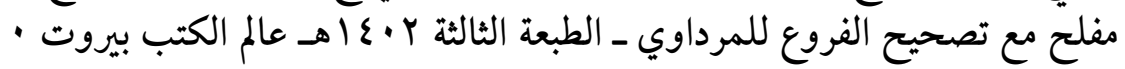

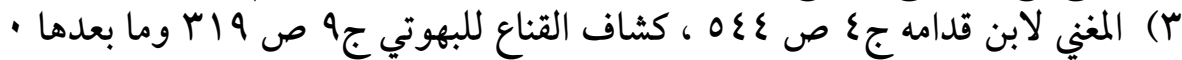


أما إذا ثبت أن جناية العجماء كانت بتقصير من صاحب اليد عليها، فإن

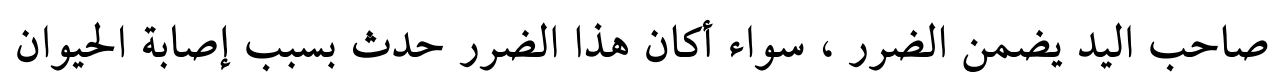

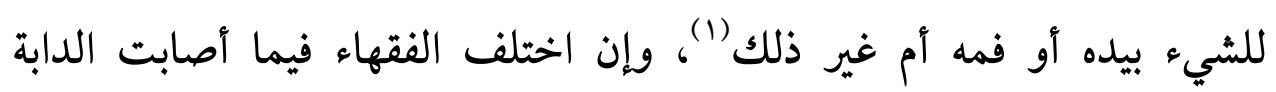
برجلها على الوجه السابق ذكره .

وصاحب اليد على الحيوان يضمن ضرره حتى ولو كان هذا الضرر ناتجاً

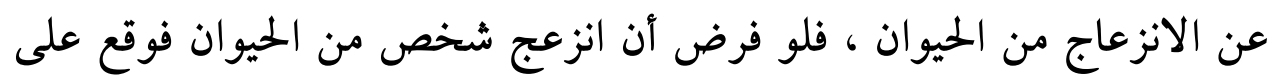

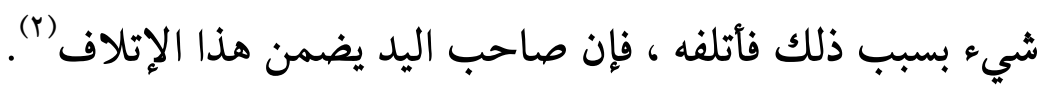
وإذا حدث ضرر من الحيوان ، فإن صاحب اليد يضمنه حتى ولو كان

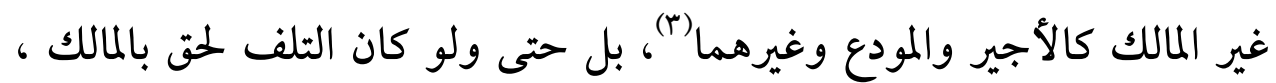

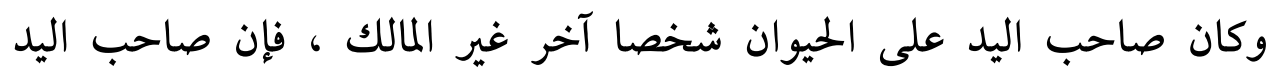

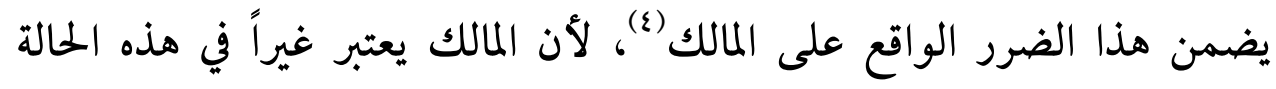

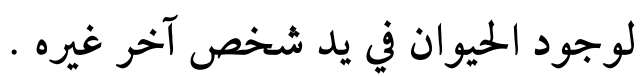

بيد أنه يشترط لضمان الضرر الحادث من الحيوان ، ألا يكون مالك المال

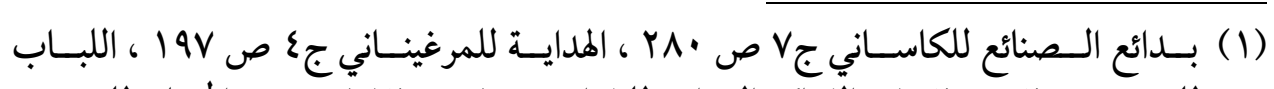

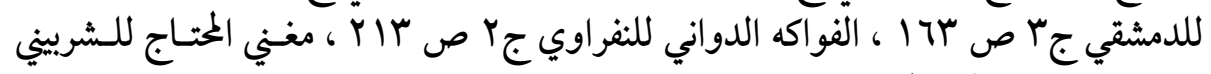

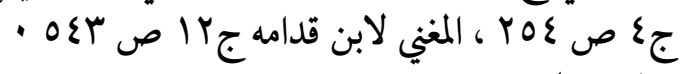

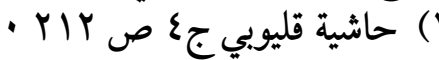

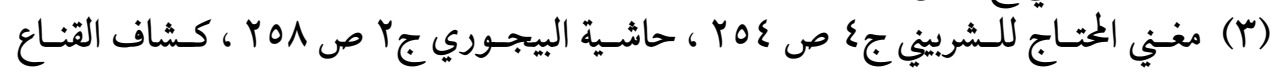

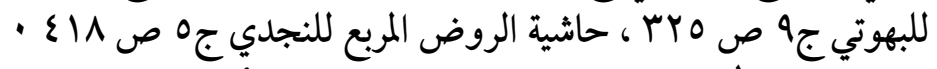

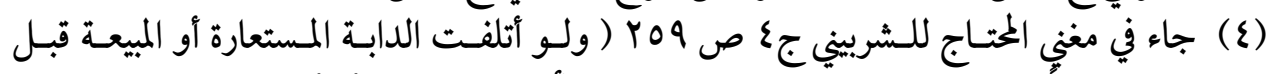

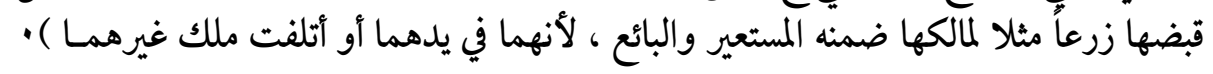

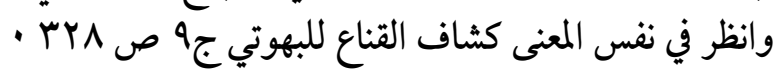


المضرور قد قصر في حفظ ماله ، فإن قصر المالك كما لو وضع ماله في الطريق أو عرضه للدابة ، فلا ضمان على صاحب اليد على الحيوان ، لتفريط مالك المال فهو المضيع لماله (1).

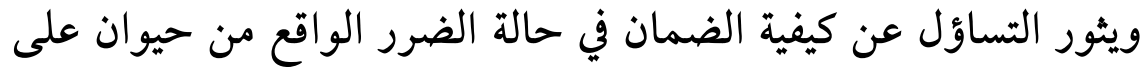
حيوان آخر ، كما لو اصطدم الفارسان ، فماتت الدابتان . وقد اختلف الفقهاء في الإجابة على هذا التساؤل على قولين : القول الأول : ذهب جمهور الفقهاء ( أبو حنيفة وصاحباه(r) والمالكية(r) والحنابلة(ع) ) إلى أن كل واحد من المصطدمين ضامن ما تلف من الآخر ، سواء كانت الدابتان

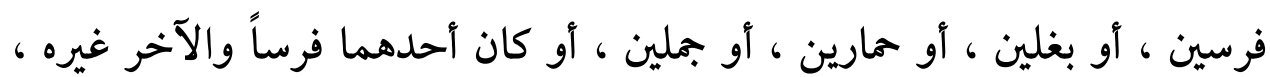

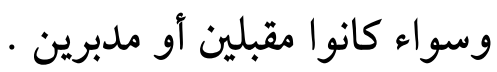
ووجه مذا القول :

أن التلف حصل بسبب فعليهما ، فوجب على كل منهما ضمان ما تلف بسبب

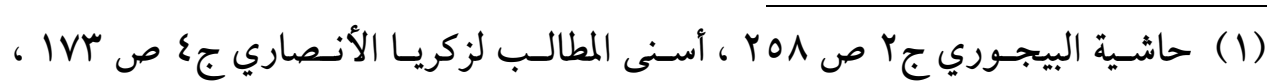

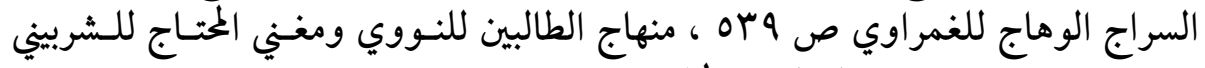

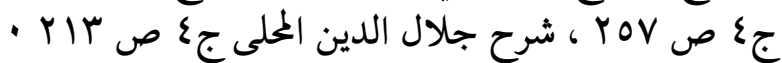

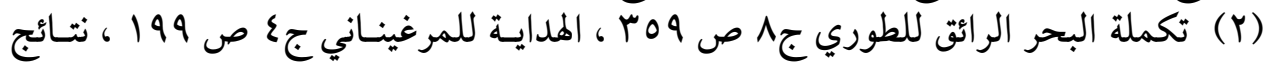

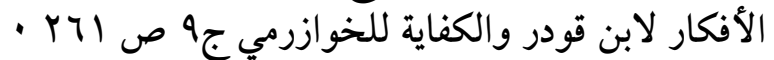

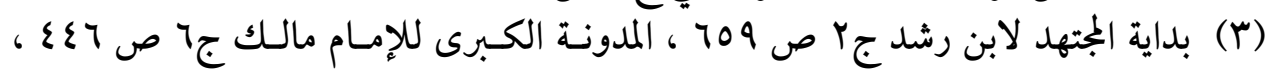

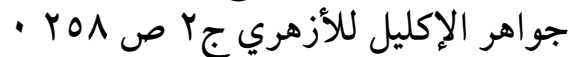

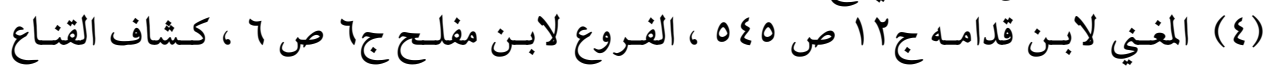

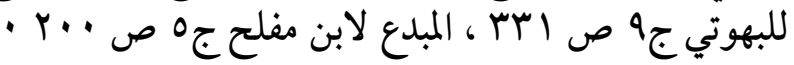


$(Y \mid \Lambda)$

فعله (1)

وعلى ذلك ، فإن قيمة الدابتين إن تساويا ، تقاصتا وسقطتا ، وإن كانت

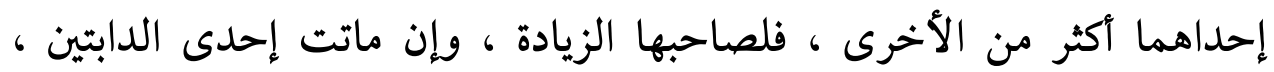

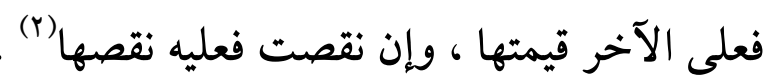

القول الثاني : ذهب زفر (َ) والشافعية() إلى أن على كل واحد من المصطدمين نصف قيمة ما تلف من الآخر . دمبر

ووجه مذا القول :

أن التلف حدث باشتراكهما في الإتلاف وفعل كل منهما هدر في حق نفسه مضمون في حق صاحبه (0)، فكان الضمان منقسما عليهما .

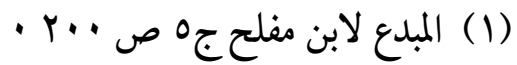

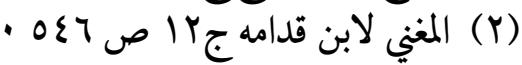

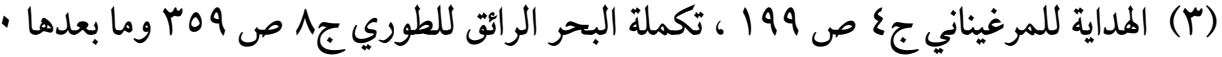

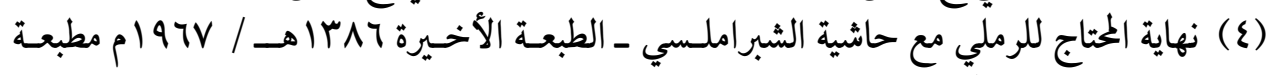

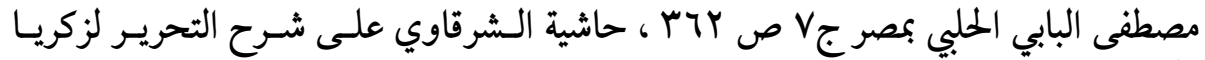

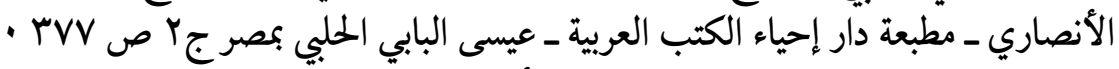

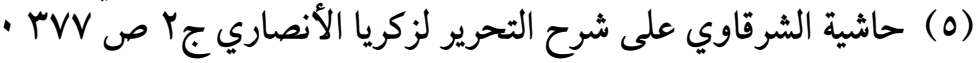




\section{المطلب الثالث}

\section{الموازنة بين القانوز الملدني والفقه الإسلامي}

\section{في شروط قيام المسئولية عن فعل الحيوان}

بالتأمل في شروط قيام المسئولية عن فعل الحيوان في القانون المدني ، وشروط

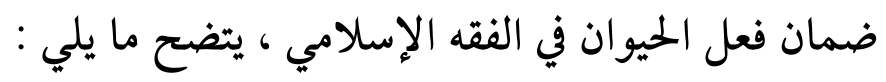

ا ـ يتفق القانون المدني مع الفقه الإسلامي في اشتراط وجود الحيوان بيد

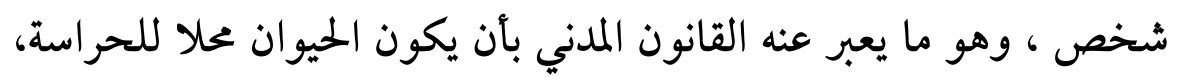

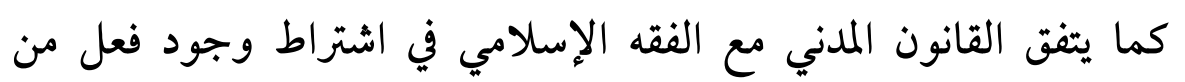

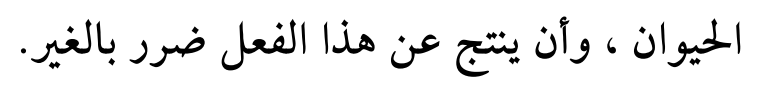
وبخصوص شرط وجود فعل من الحيوان ، فإنه يجب أن يكون الحيوان قد

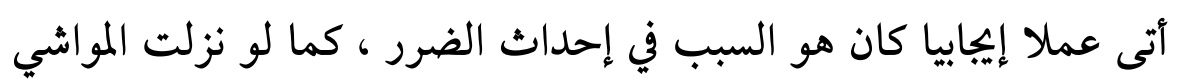

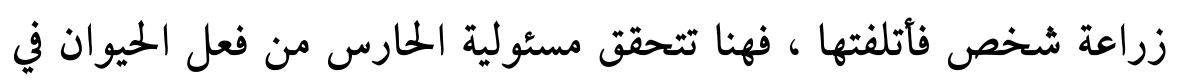

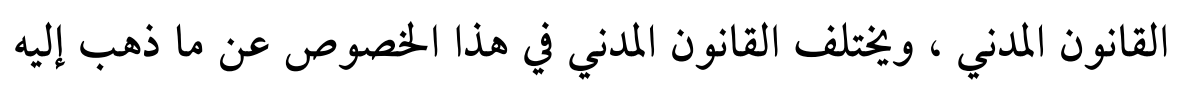

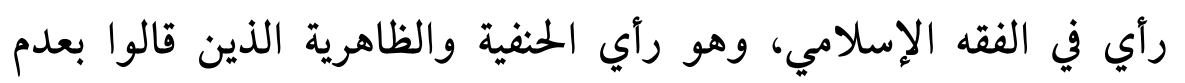

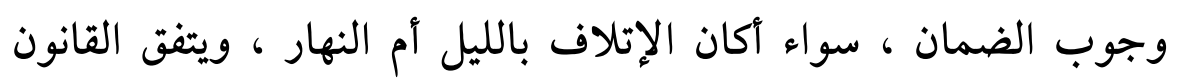

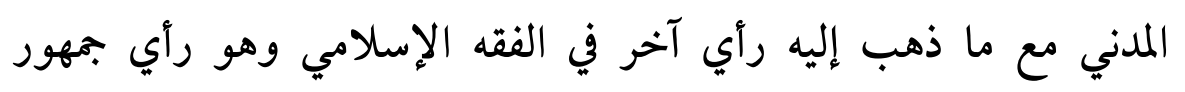

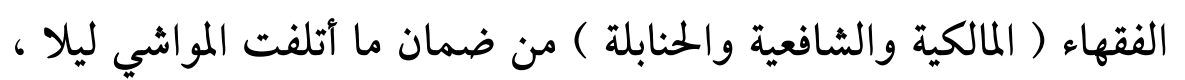

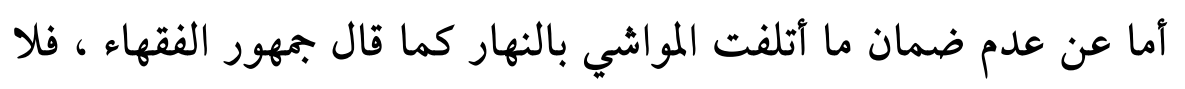


يوجد في فقه القانون المدني ما يفيد عدم مسئولية الحارس عن ما أتلفت

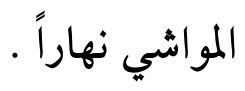

أما إذا لم يكن الحيوان قد أتى عملاً إييابيا في إحداث الضرر ، بأن كان

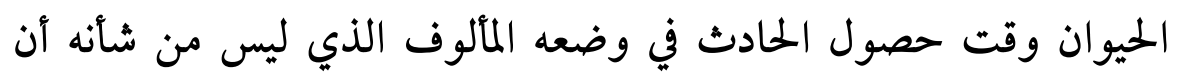

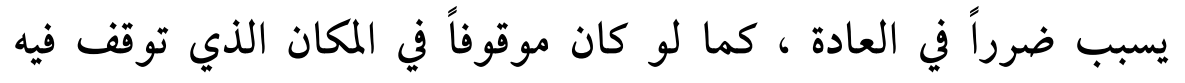

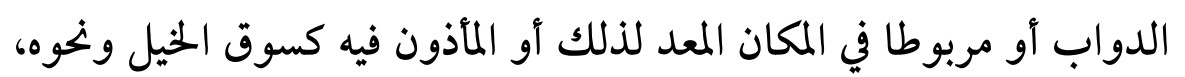

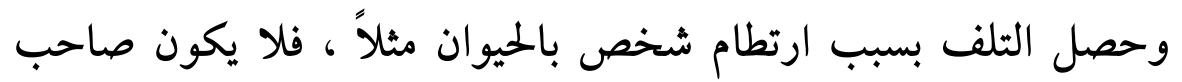

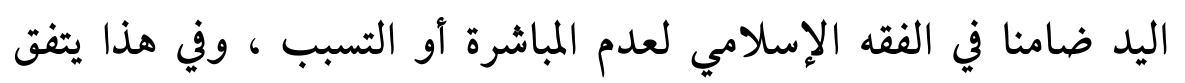

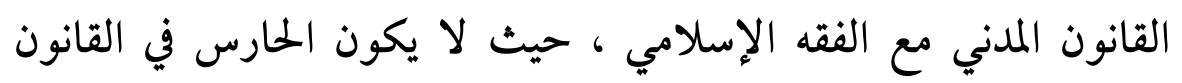

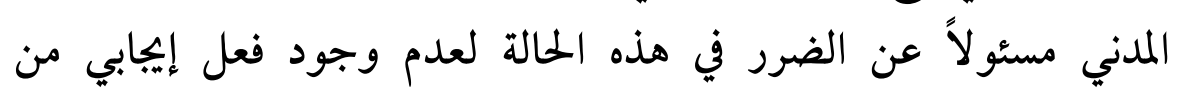

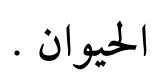

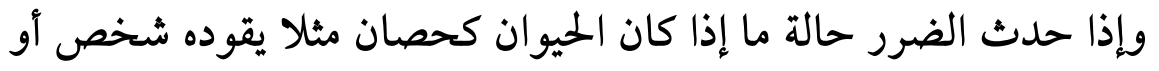

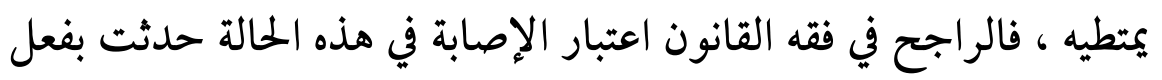
الحيوان لا بفعل الإنسان ، ومن ثم يعفي المضرور من عبء إثبات الخبات الخطأ ،

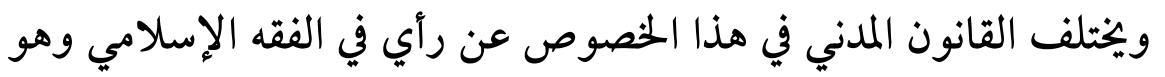
رأي الشافعية الذين يوجبون الضمان على صاحب اليد في ما تتلفه البهائم مطلقا بحجة أن صاحب اليد إذا كان معها كان فعلها منسوباً إليه وجنايتها

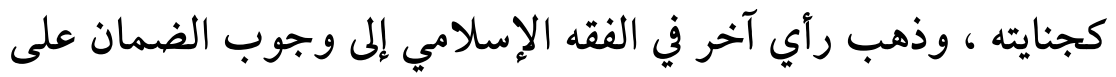

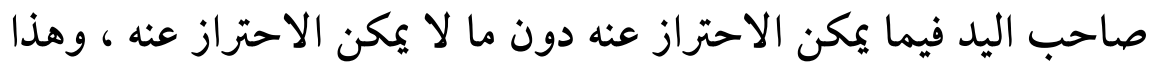

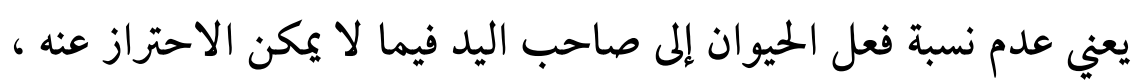




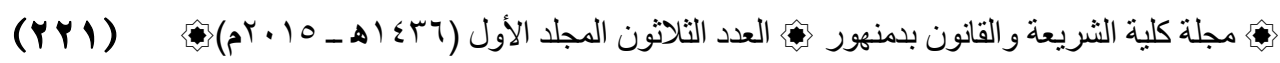

$$
\text { ويقترب القانون المدني مع هذا الرأي الأخير . }
$$

ب - ـيتفق القانون المدني مع الفقه الإسلامي في أنه يلزم لتحقق مسئولية الحارس

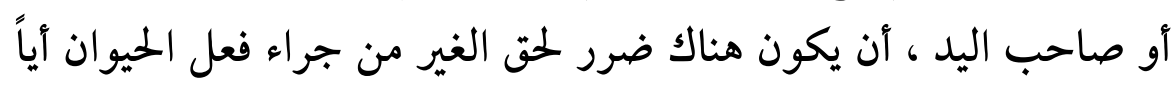
كان هذا الضرر ، أي سواء أكان هذا الضرر جرحاً أم كدماً أم ذعراً . وإذا حدث الضرر فإن صاحب اليد أو الحارس يكون مسئولاً عنه حتى كإن

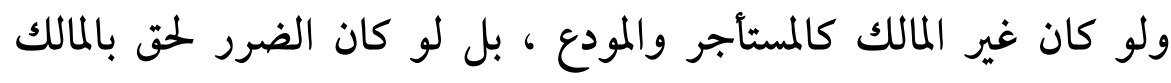

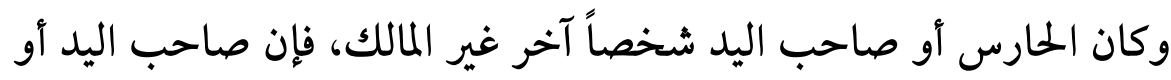

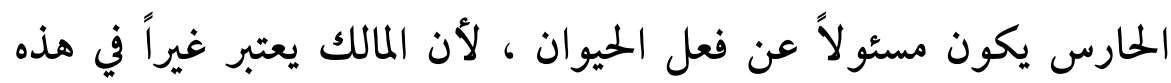

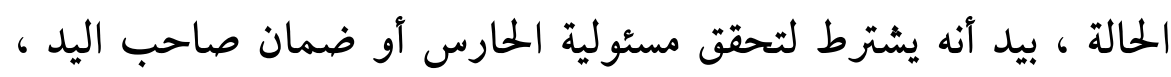

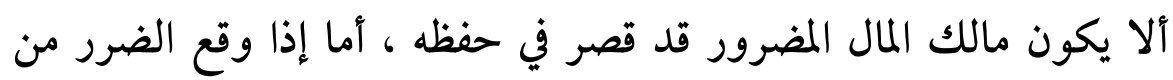

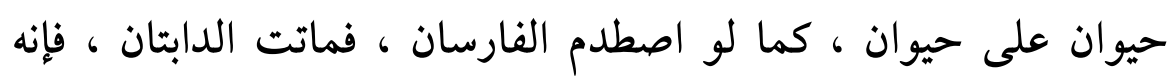
يجيوز في القانون المدني أن يتمسك كل واحئ داحد من الفارسين تجاه الآخر بالمادة

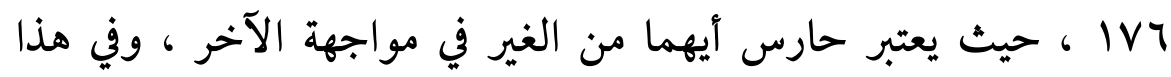

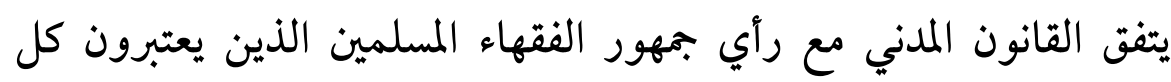
واحد من المصطدمين ضامن ما تلف من الآخر . 


\section{المبحث الثالث}

\section{أساس قيام المسئولية عن فعل الحيوان}

ويحتوي على ثلاثة مطالب :

\section{المطب الأول \\ أساس قيام المسئولية عن فعل الحيوان في الثقانوز الملدي}

اختلف الفقه القانوني في أساس قيام المسئولية عن فعل الحيوان، فذهب رأي

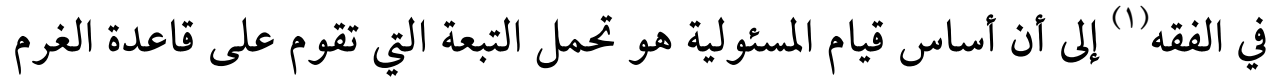

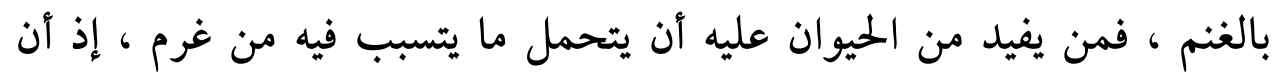

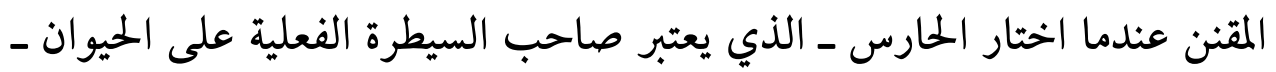

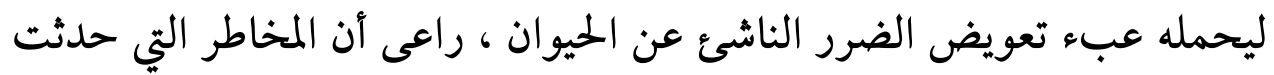

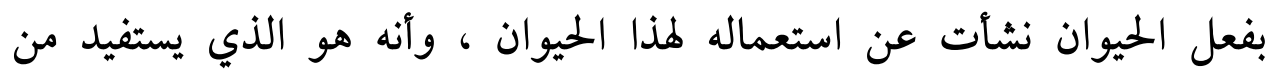

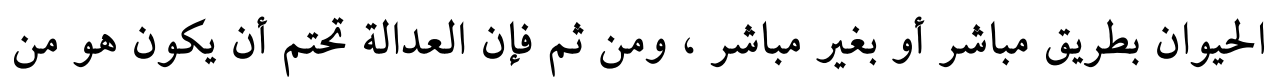

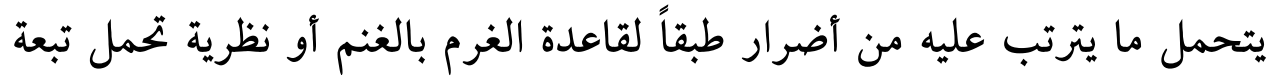
المخاطر كما يطلق عليها أحيانا .

بيد أنه أخذ على هذا الرأي ، أنه لو كان هذا التأصيل صحيحاً لوجبت

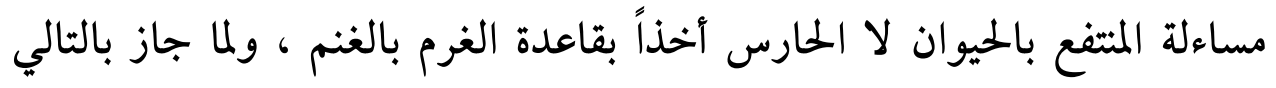


دفع هذه المسئولية بنفي رابطة السببية(1) .

لذلك ذهب الرآي الغالب في الفقه(r) وقضاء النقض في مصر (r) إلى أن

أساس مسئولية حارس الحيوان وحارس الأشياء عموماً هو الخطأ المفترض ، ويتمثل الخطأ فيما يسمى بالخطأ في الحراسة وهو إفلات زمام الحيوان من سيطرة

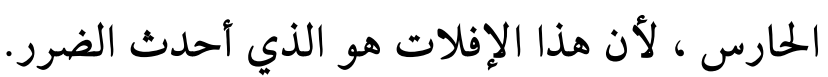

ولما كان الخطأ مفترضا فإن المضرور لا يكلف بإثباته وإنما يكفيه أن يثبت

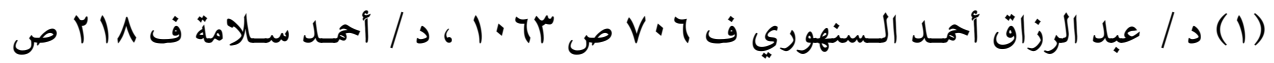

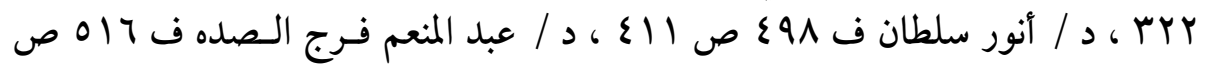

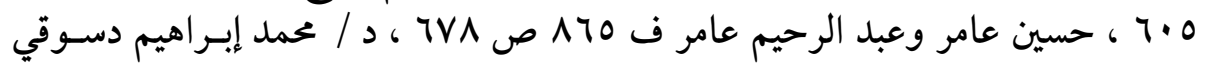

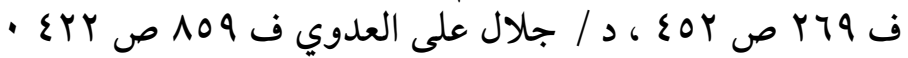

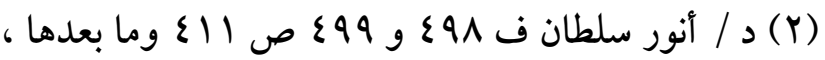

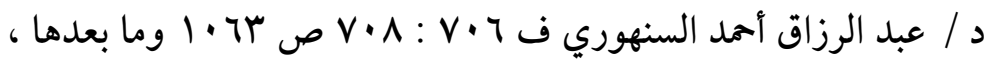

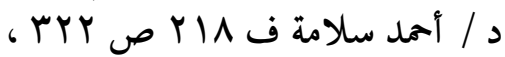

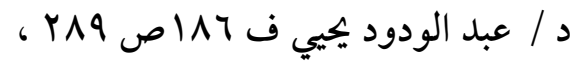

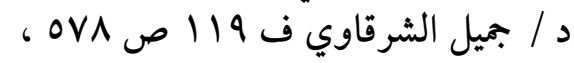
حسين عامر وعبد الرحيم عامر ف

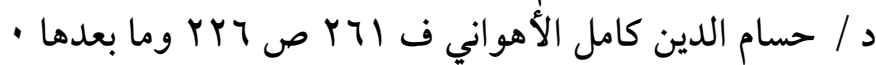

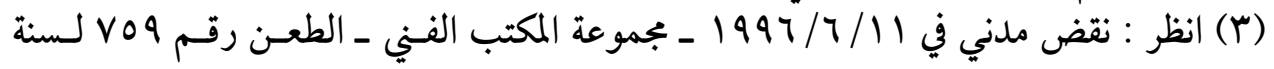

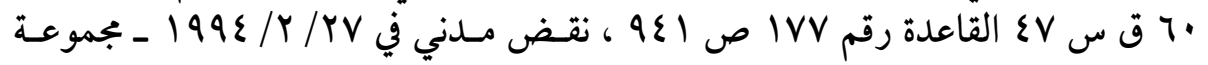

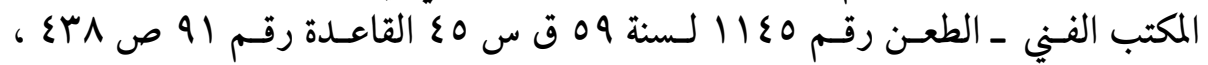

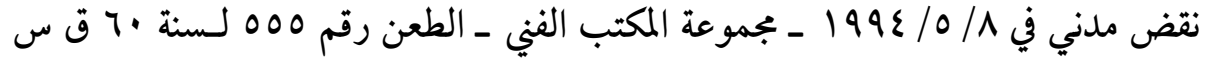

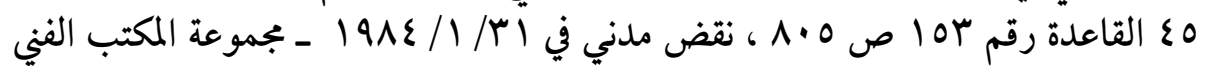

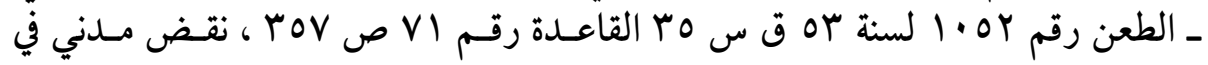

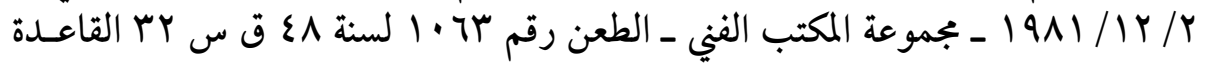


الضرر ويثبت أنه قد حدث بفعل الحيوان ، أي أن الحيوان قد تدخل تدخلاً

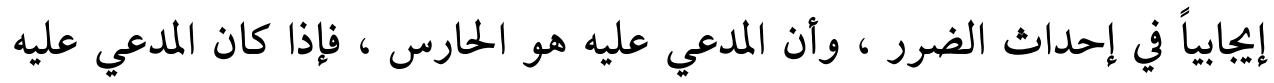

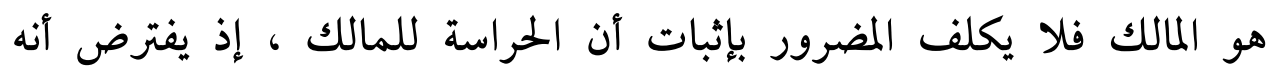

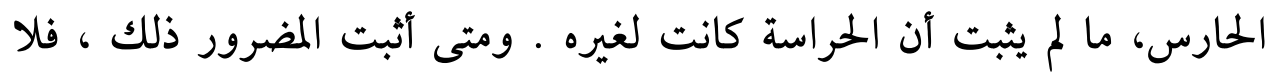

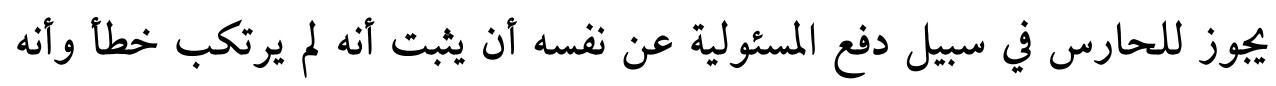

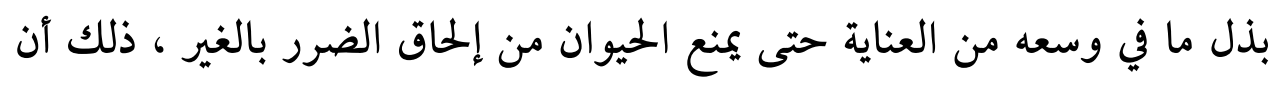

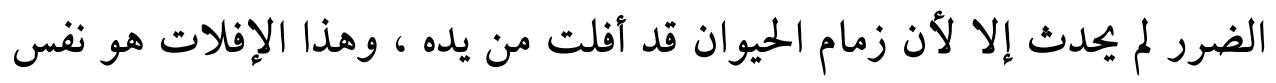

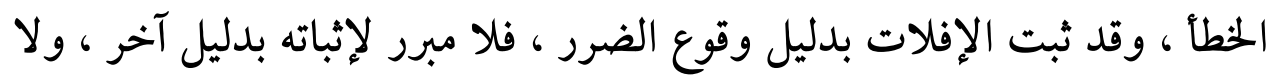

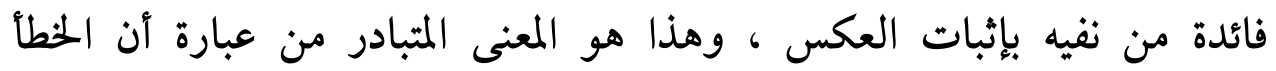

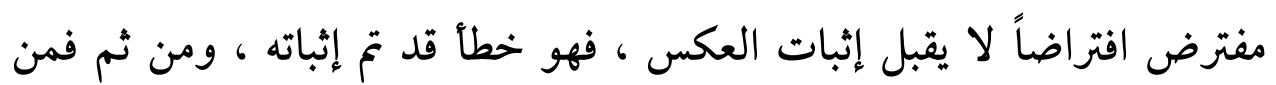

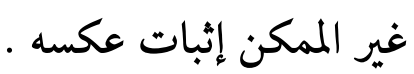

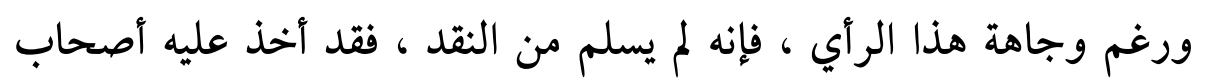

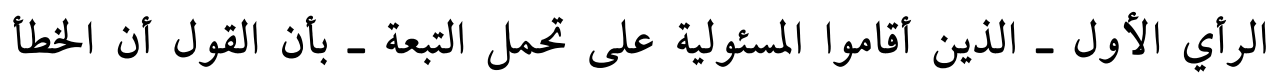

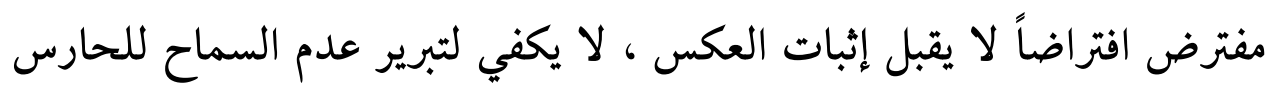

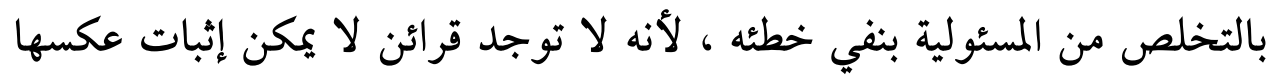

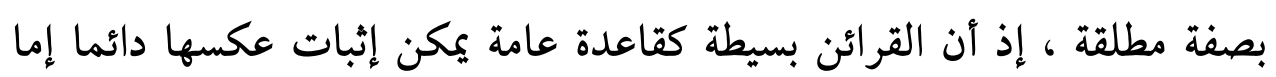

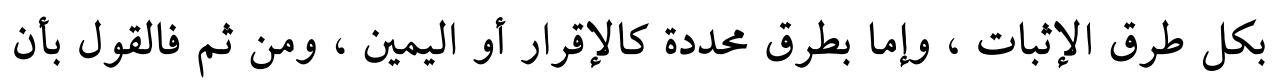

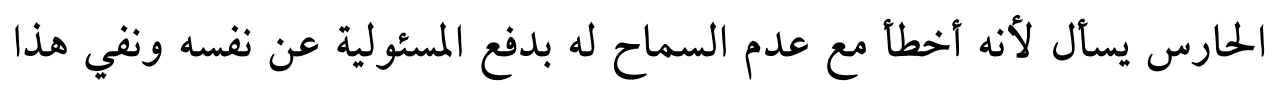

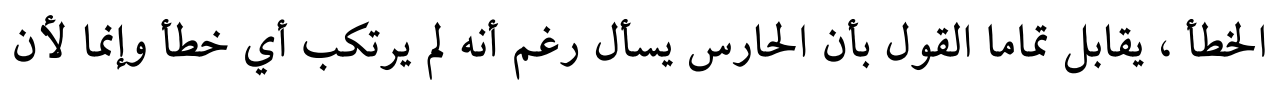


الضرر قد حدث بفعل الحيوان الذي في حراسته(1)

ويمكن الرد على هذا الزعم ، بما ذهب إليه جانب آخر من الفقه (r) بأن

الأمر لا يتعلق هنا بقرينة على الخطأ غير قابلة لإثبات العكس، ولكنه يتعلق بخطأ

ثابت ، فيعتبر أساس المسئولية خطأ ثابتاً حدث من حارس الحيوان هو الخطأ في

الحراسة ، فمتى ثبت أن الضرر قد حدث بفعل الحيوان ، فقد ثبت الخطأ ، ويفرض في هذا الخطا أنه غير راجع إلى سبب أجنبي عن الحارس ، فتكون هذه المسئولية مبنية على خطأ ثابت في جانب الحارس ، ومن ثم لا يمكن القول بالسماح للحارس بنفي شيء قد ثبت أو تكليف المضرور بإثبات هذا الخطأ

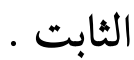

وذهب رأي ثالث (r) إلى أبعد من ذلك ، فأقام المسئولية التي تقع على عاتق

حارس الحيوان على فكرة التضامن الاجتماعي وليس على أساس الخطأ ، ووجه هذا الرأي : أن المادة IVT ملدني التي تحكم مسئولية حارس الحيوان ، تتضمن قاعدة موضوعية أي أنها تقرر حكما موضوعياً وليس قاعدة إثبات ، ولذا فهي لا تتضمن قرينة قانونية على خطأ الحارس ، والقول بأنها تشتمل على قرينة قاطعة لا تقبل إثبات العكس قول ليس له معنى قانوني ، لأن فكرة القرينة القاطعة فكرة مشكوك في صحتها . وإذا كان المقنن قد استعان بفكرة القرينة حينما قرر مسئولية حارس الحيوان،

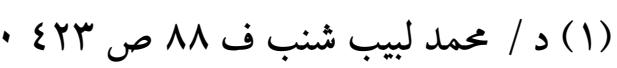

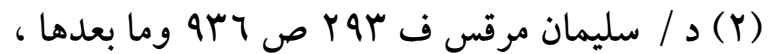

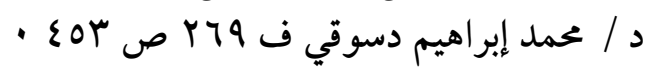

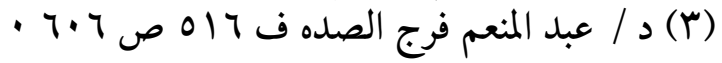


(YYY)

فقدر أن الضرر الذي حدث للغير بفعل الحيوان نشأ نتيجة خطأ من الحارس بإفلات

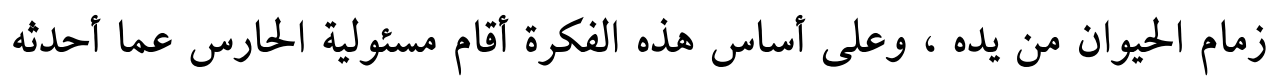

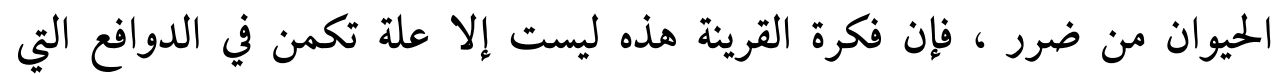

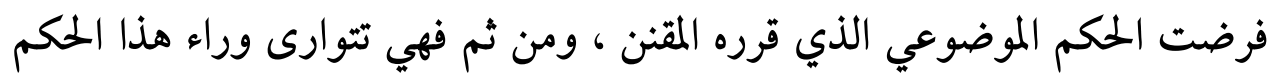

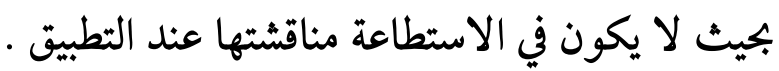

يضاف إلى ذلك أن فكرة القرينة ليست هي العلة الوحيدة التي تؤسس عليها

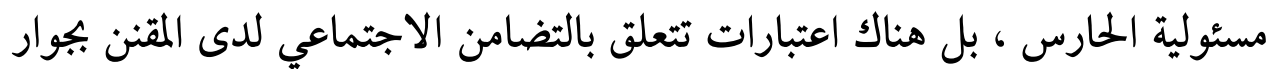

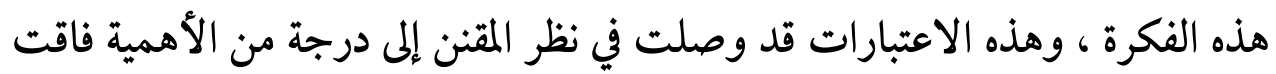

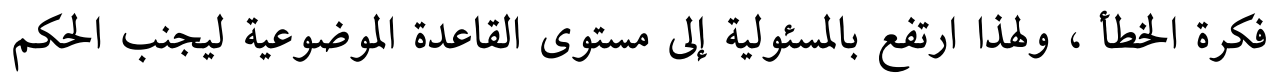

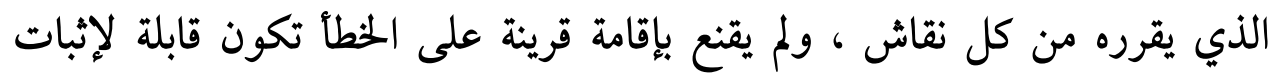

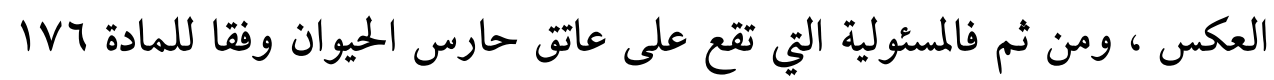

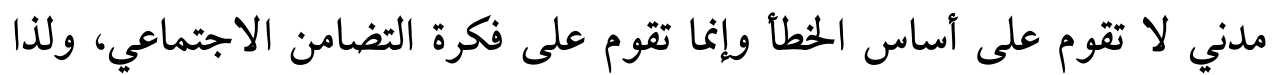

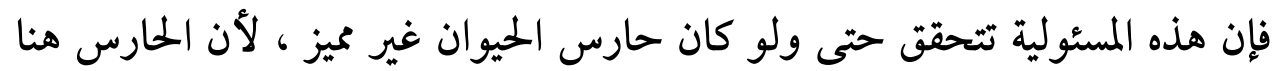

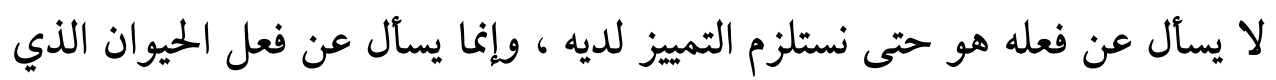

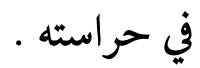

وقد أخذ على هذا الرأي : أنه يكتفي بتأسيس مسئولية الحارس على فكرة

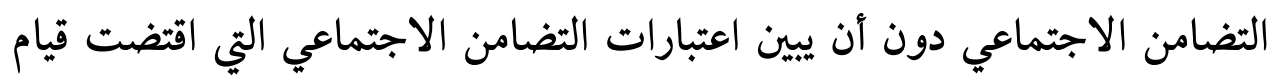

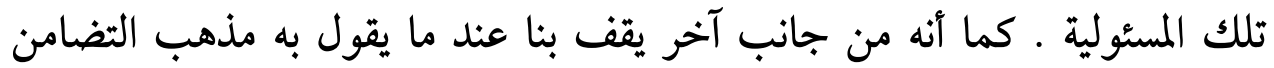

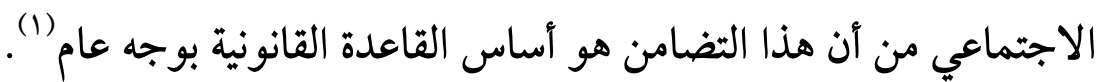




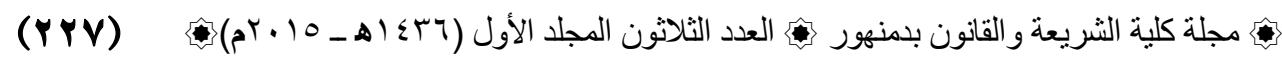
لذلك أرى أنه لا مناص من الأخذ بالمعيار الذي ذهب إليه غالب الفقه وأيده

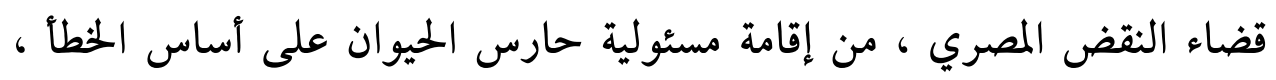

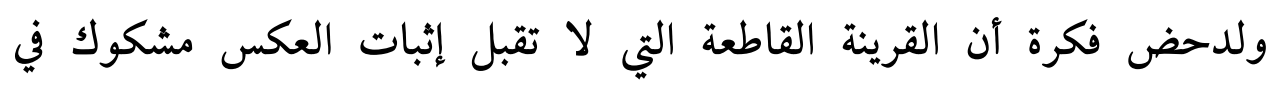

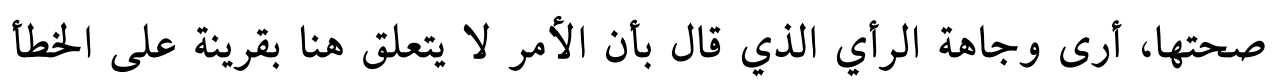

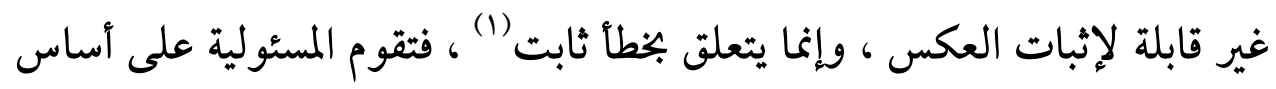

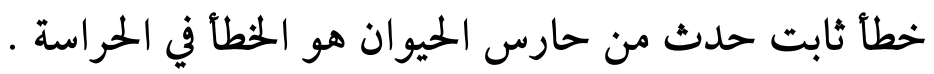


(YYA)

\section{المطلب الثاني}

\section{أساس ضماز فعل الحيوان في الفقه الإسلامي}

أساس ضمان فعل الحيوان في الفقه الإسلامي هو المباشرة أو التعدي

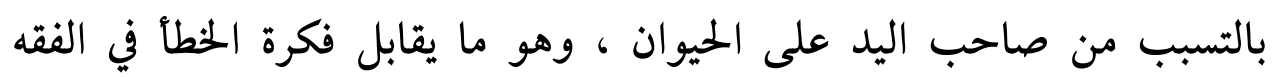

القانوني.

والمباشر ضامن متعديا كان أو لم يكن ·

والمتسبب يضمن إذا كان متعديا" .

ولما كان المباشر يضمن سواء أكان متعديا أم لم يكن ، أي سواء أكان الإتلاف

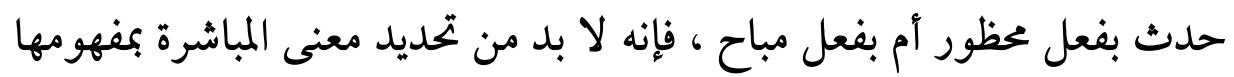

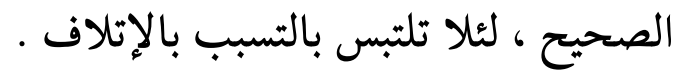

وقد عرف الفقهاء المباشر بأنه : " من يحصل التلف بفعله من غير أن يتخلل بين فعله والتلف فعل مختار "(r). وتظهر المباشرة والتعدي بالتسبب من صاحب اليد على الحيوان أو غيره، في مسائل متعددة ، أذكر منها ما يلي :

1 ـ إذا أدخل واحد دابته في ملك غيره بدون إذن صاحبه فإنه يضمن ضرر تلك الدابة وخسارها في كل حال أي سواء كان راكبا آو سائقا أو قائداً موجوداً

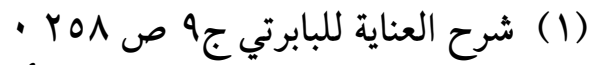

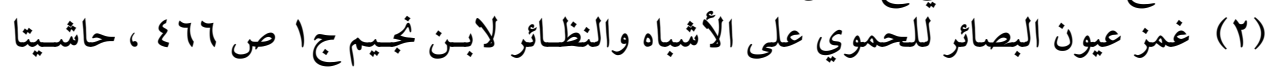

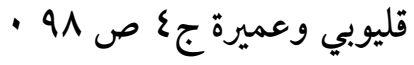


معها أو غير موجود ، وسواء وطئت الدابة ما أصابت بيدها أو رجلها أو

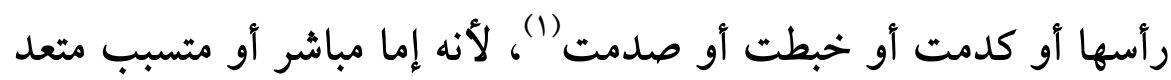

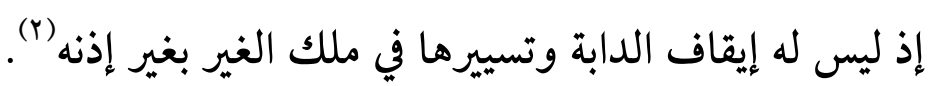

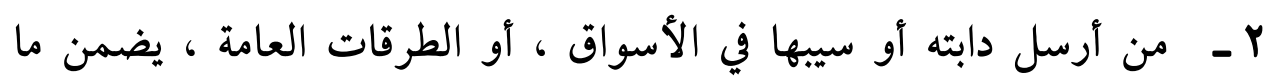

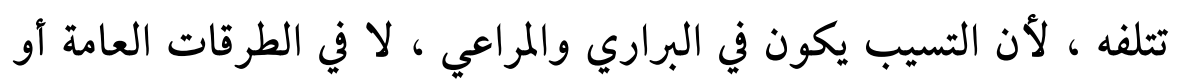

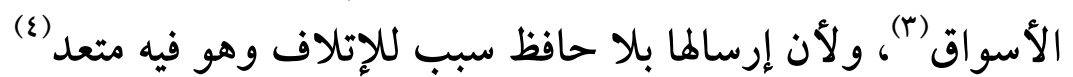

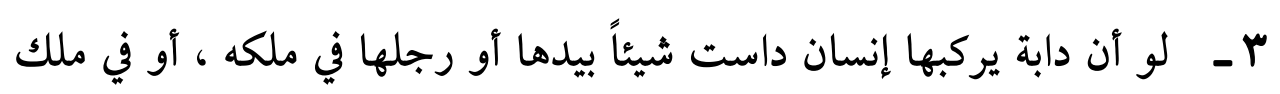

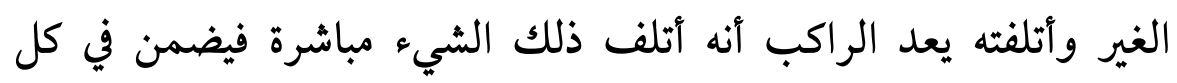
حال وإن داس رجلا فقتله ضمن أيضاً ، لأنه حيث قتله مباشرة فيضمن وإن لم

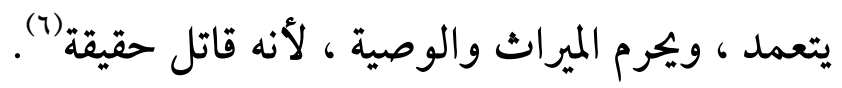

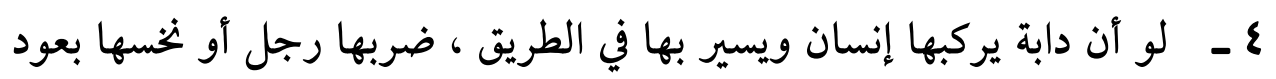

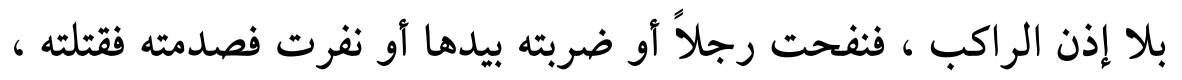

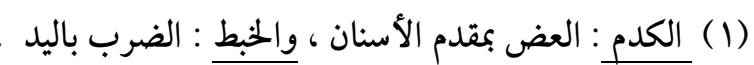

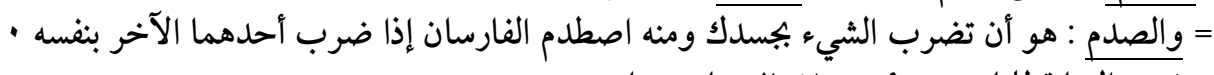

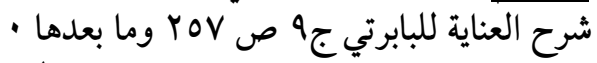

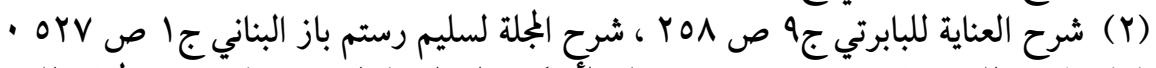

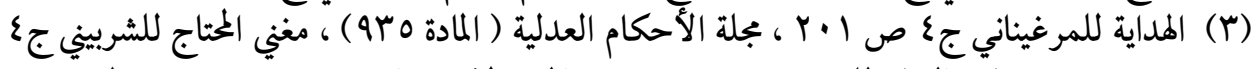

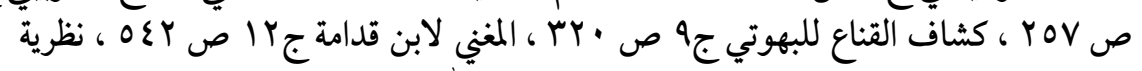

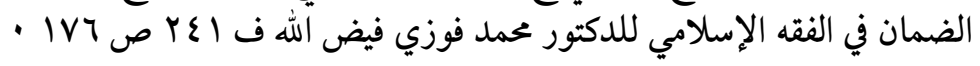

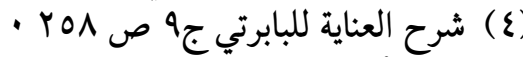

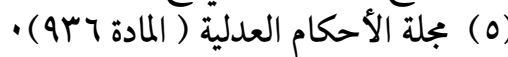

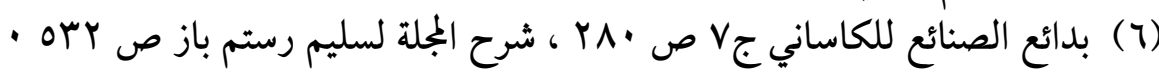


كان الضمان على الضارب أو الناخس دون الراكب ، لأن الراكب

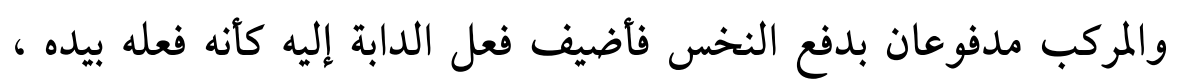

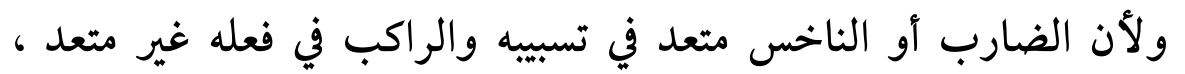

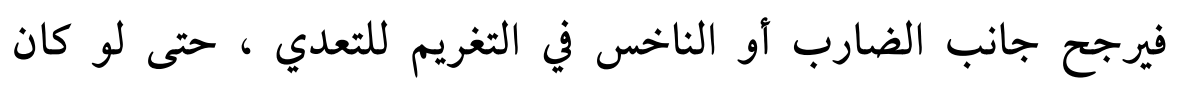

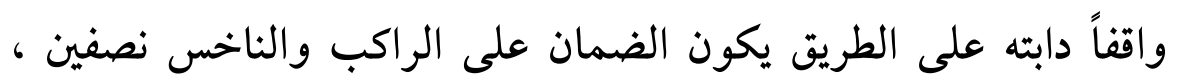
لأن الراكب متعد في الإيقاف أيضاً (1) .

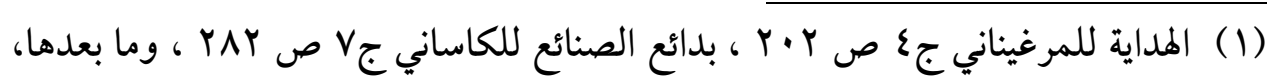

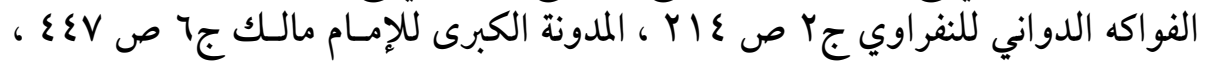

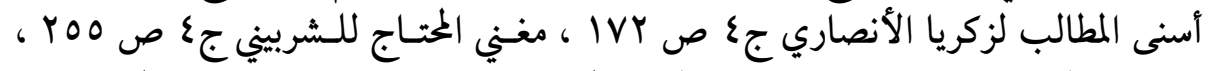

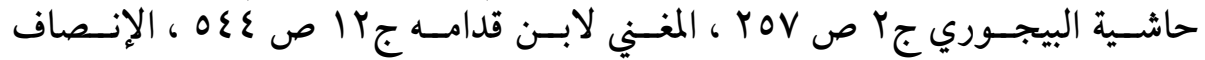

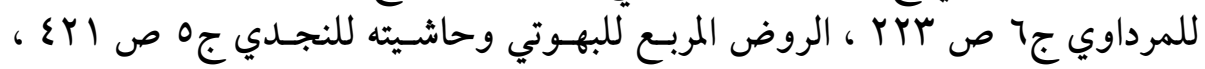

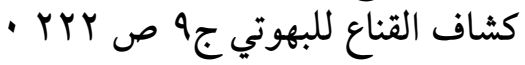




\section{المطلب الثالث}

\section{الموازنة بين القانوز الملدني والفقه الإسلامي في أساس قيام المسئولية عن فعل الحيوان}

تعددت الآراء في الفقه القانوني حول أساس قيام المسئولية عن فعل الحيوان ،

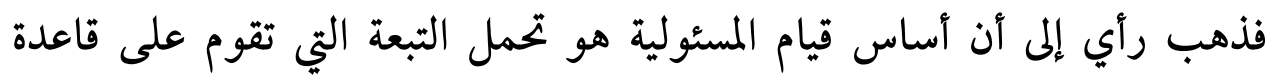

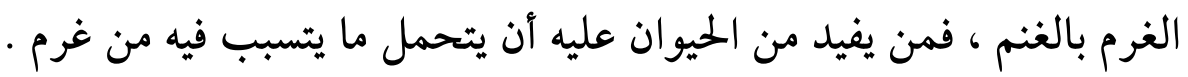
وقد أخذ على هذا الرأي أنه لو كان هذا التأصيل صحيحاً لوجبت مساءلة

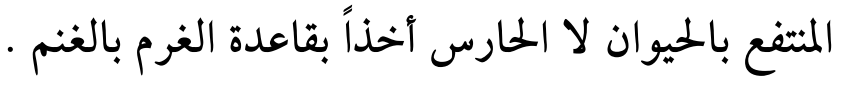
وذهب رأي آخر إلى أن المسئولية التي تقع على عاتق حارس الحيوان تقوم

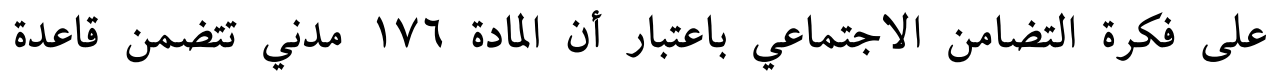
موضوعية وليس قاعدة إثبات .

وقد أخذ على هذا الرأي أنه لم يبين اعتبارات التضامن الاجتماعي التي

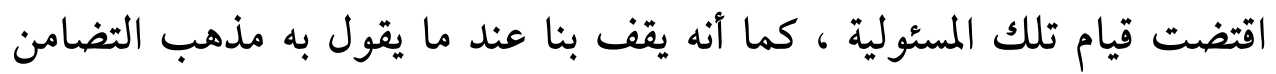
الاجتماعي من أن هذا التضامن هو أساس القاعدة .

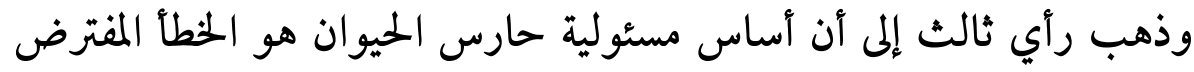

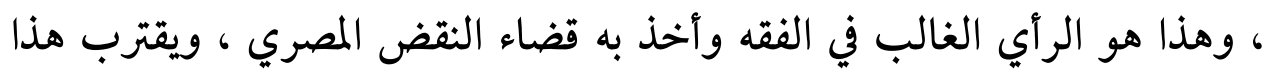

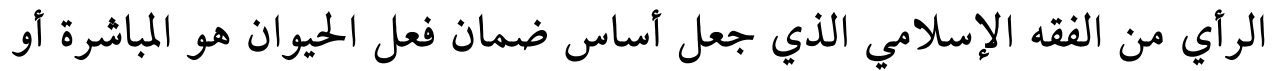

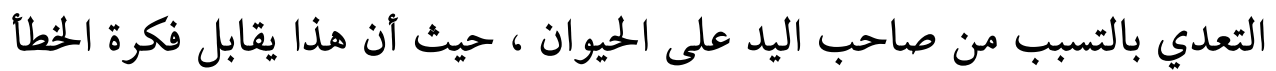

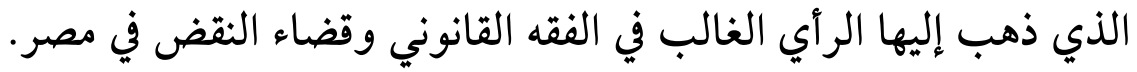




\section{المبحث الرابع}

\section{وسيلة دفع المسئولية عن فعل الحيوان}

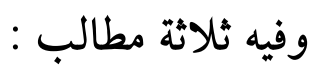

\section{المطلب الأول}

\section{وسيلة دفع المسئولية عن فعل الحيوان في القانوز الملدني}

يذهب الرأي الذي أقام مسئولية الحارس على فكرة التضامن الاجتماعي

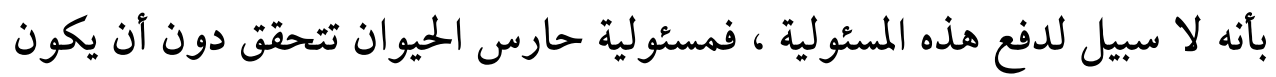

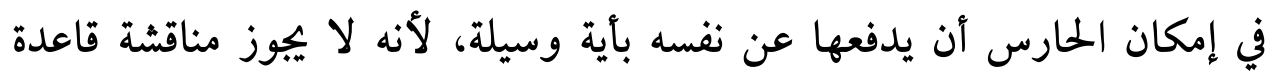
موضوعية لاستبعاد تطبيقها (1).

أما الرأي الغالب في الفقه والذي أقام مسئولية الحارس على أساس الخطاً ،

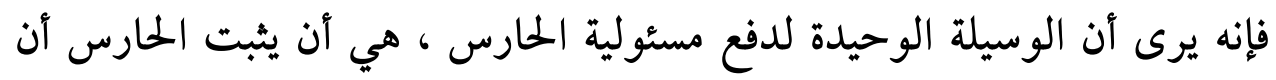

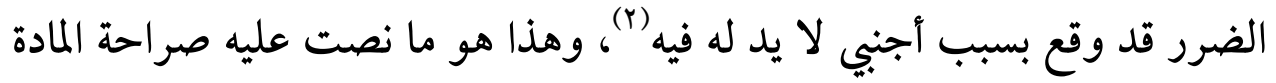

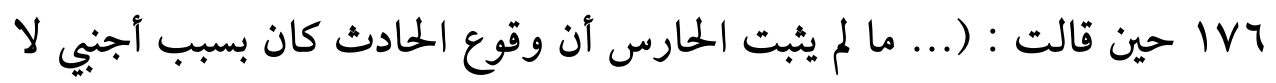

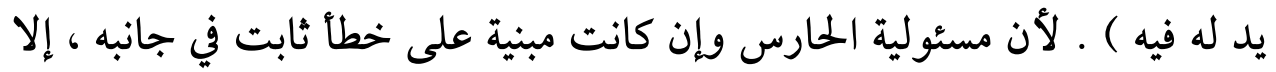

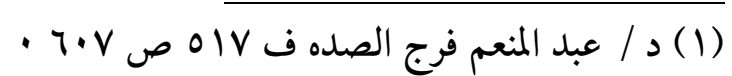

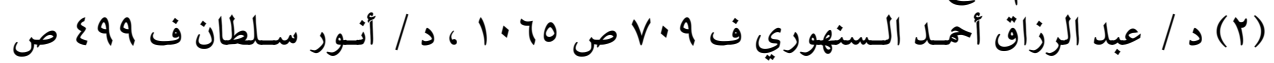

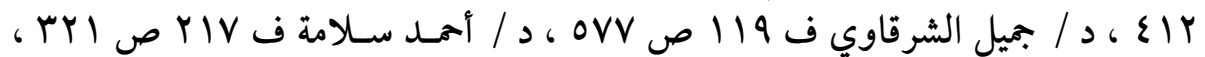

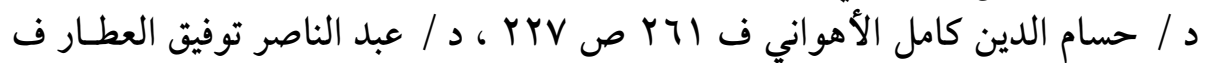


أنها أيضاً مبنية على سبيية مفترضة ، فالقرينة التي تقوم عليها هذه المسئولية هي

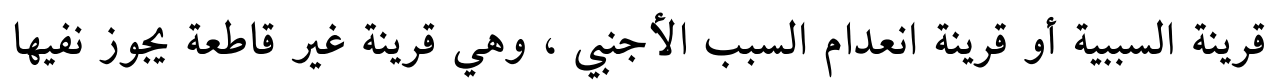

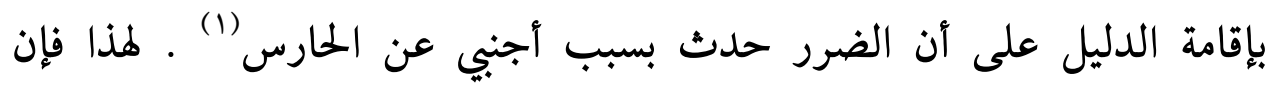

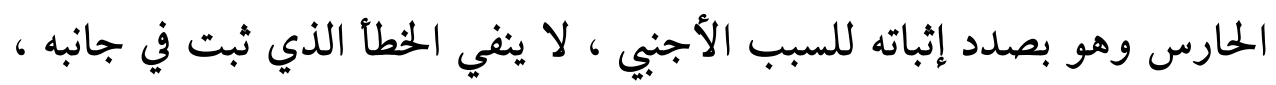

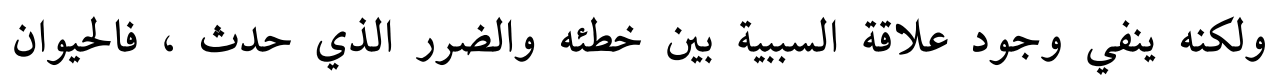

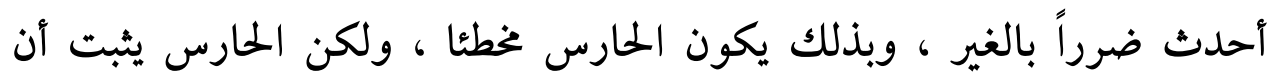

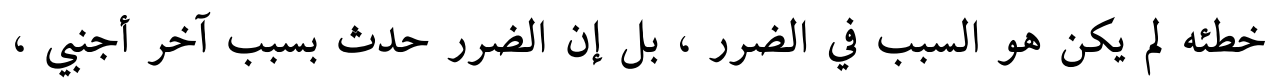

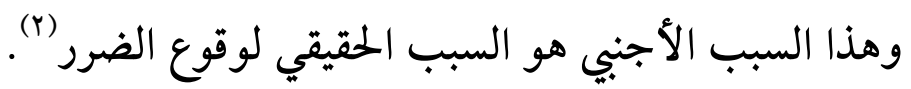
والسبب الأجنبي هو واقعة لا يد للحارس فيها جعلت من حصول الضرر أمراً محتماً.

وقد تكون هذه الواقعة من فعل الطبيعة ولا دخل لإرادة الإنسان فيها،

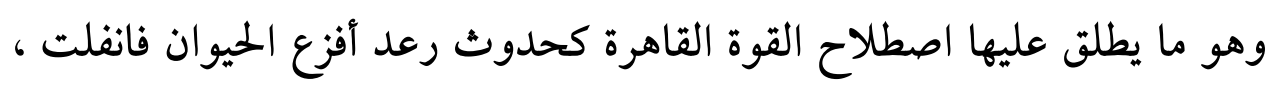

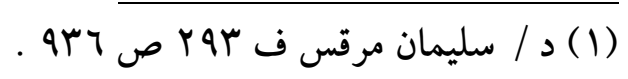

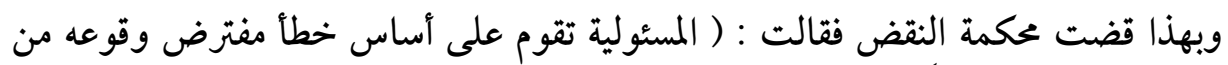

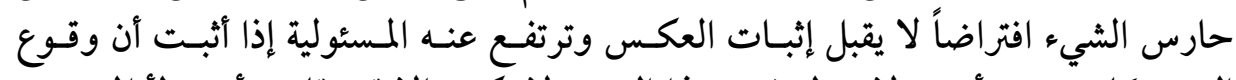

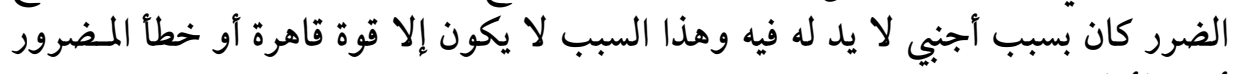

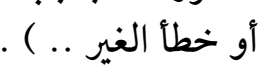

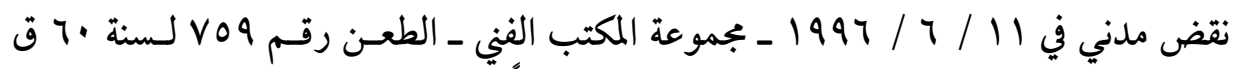

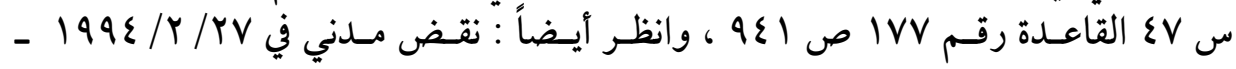

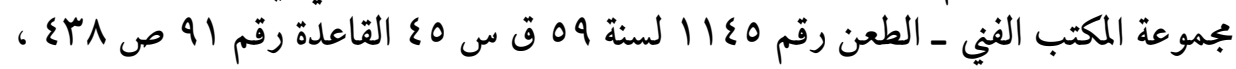

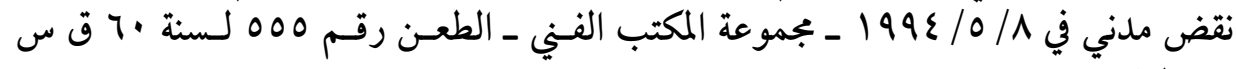

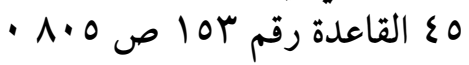

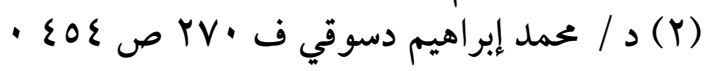


وقد تكون الواقعة من فعل الإنسان ، فإذا كانت من فعل شخص غير الحارس

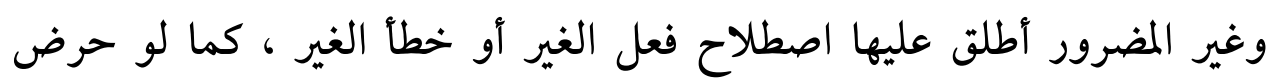

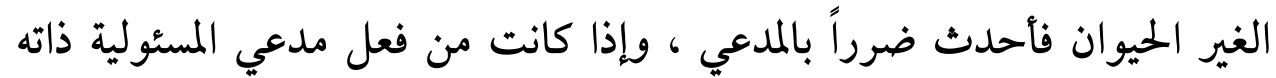

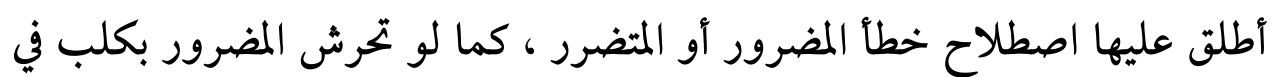
حديقة فألقاه بحجر أو مد يده بعصى فعقره الكلب (1).

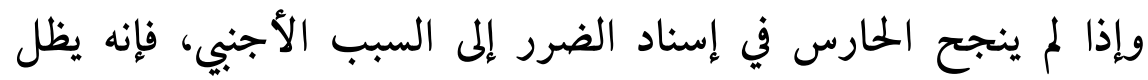

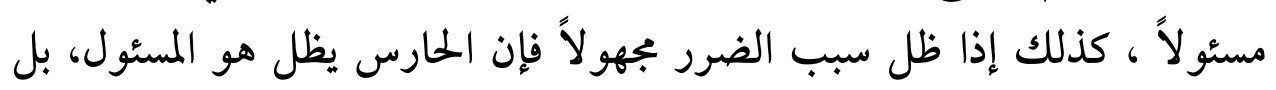

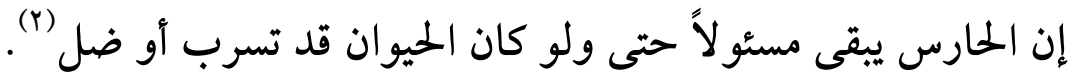

أما إذا نجح الحارس في إثبات السبب الأجنبي ، فإن رابطة السبية بين

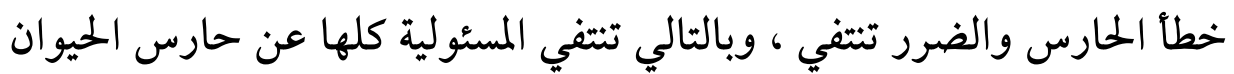

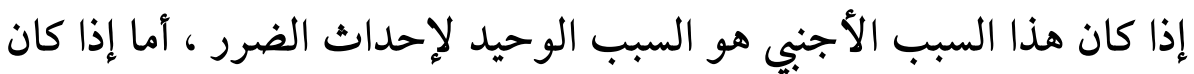

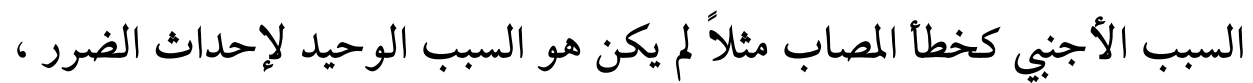

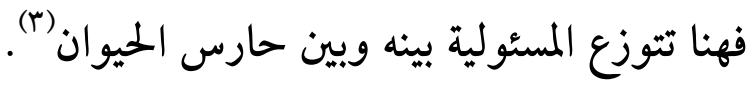

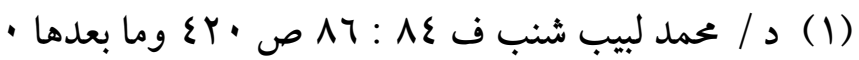

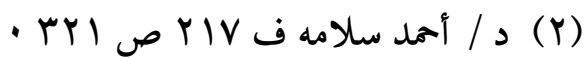

$$
\begin{aligned}
& \text { - }
\end{aligned}
$$




\section{المطلب الثاني \\ وسيلة نفي الضمان عن فعل الحيوان في الفقه الإسلامي}

الضرر الذي يحدثه الحيوان بالغير ويكون سبباً للضمان، يتحقق إما عن

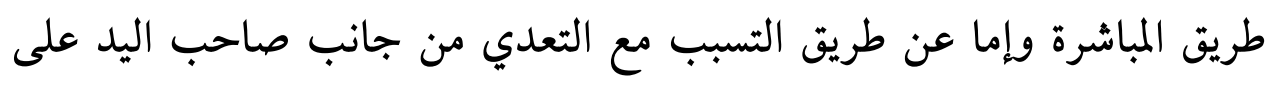

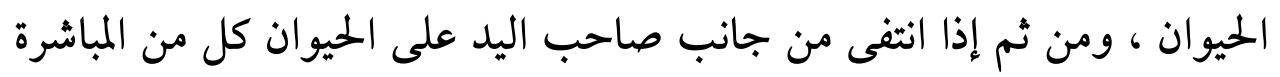

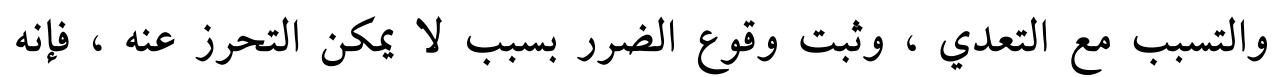

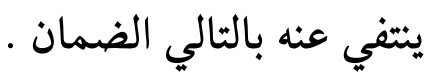

\section{ومن تطبيقات ذلك ما يلي:}

1 ـ لو انتشر من رجل الدابة غبار أو طين ولوث ثياب الغير أثناء المرور بالدابة

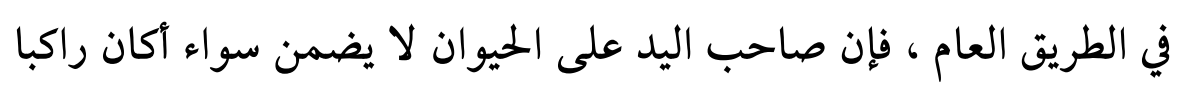

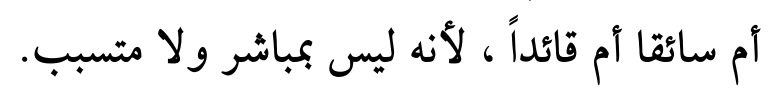

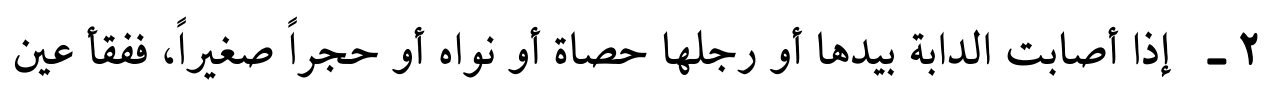

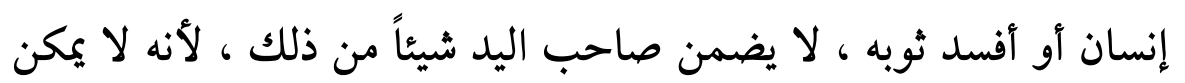

$$
\text { التحرز عنه إذ سير الدواب لا يخلو منه . }
$$

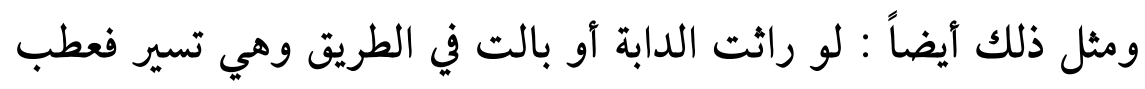
به إنسان ، لا يضمن صاحب اليد لأنه من ضرورات السير فلا ئل اليكنه

الاحتراز عنه (1).

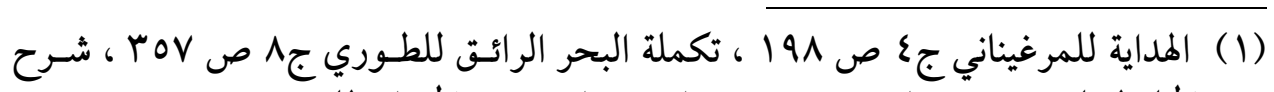

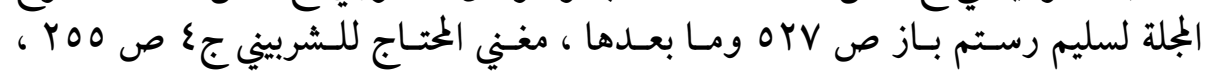


r ـ كذلك لا يضمن صاحب اليد ما نفحت الدابة أي ضربت برجلها أو ذنبها،

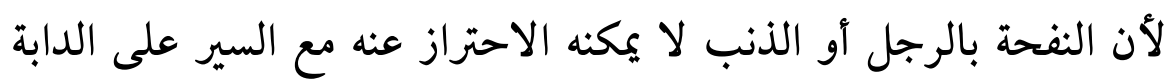

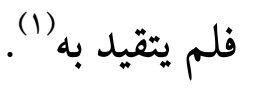

ع - لو انفلتت الدابة بنفسها ولو في الطريق أو في ملك غير صاحبها، فأصابت

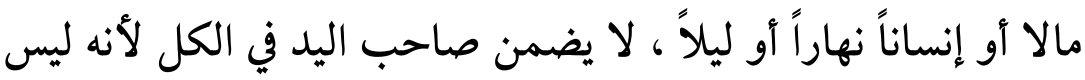

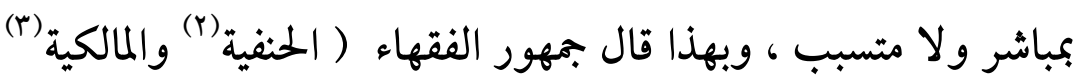

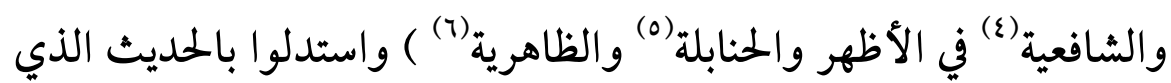

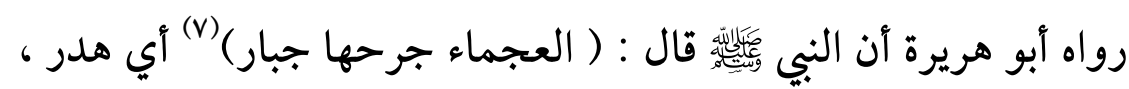

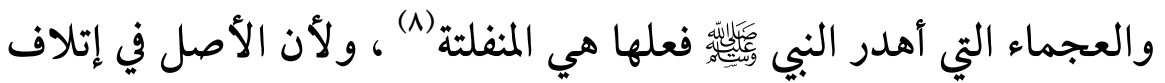

منهاج الطالبين للنـووي وشـرح جـلال الـدين المحلى جع ص با ب ، السراج الوهـاج

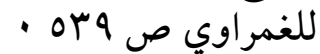

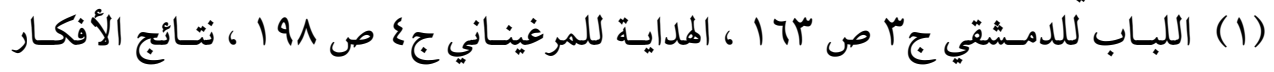

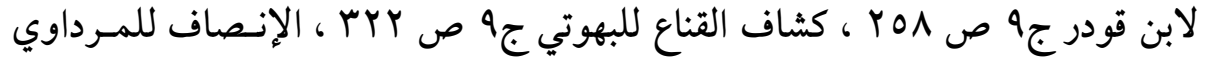

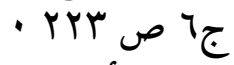

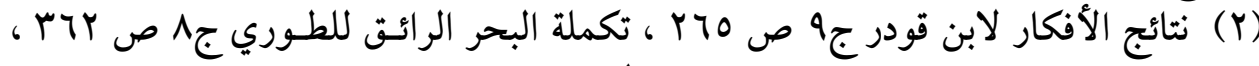

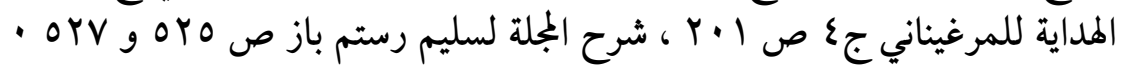

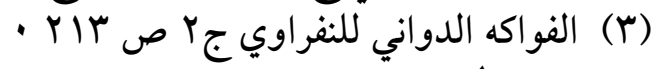

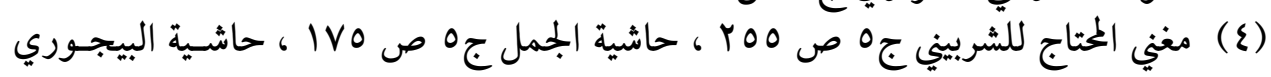

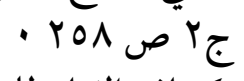

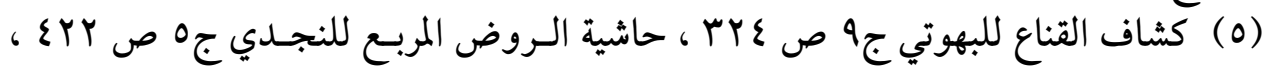

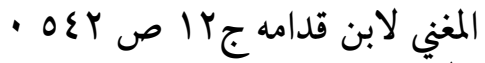

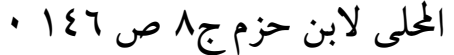

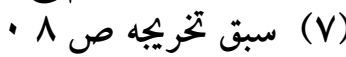

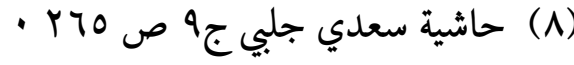


الحيوان وجنايته أنه هدر إذا وقع الفعل منه وحده ولم يمكن إسناده إلى

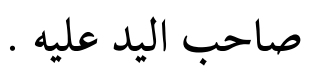

وبهذا نصت المادة 9 9 هن المجلة فقالت : ( الضرر الذي أحدثه الحيوان

$$
\text { من تلقاء نفسه لا يضمنه صاحبه ). }
$$

وعلى ذلك فكل ما كان من فعل الحيوان من غير تفريط من صاحب اليد

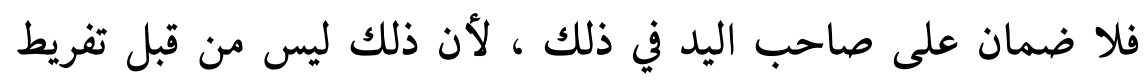

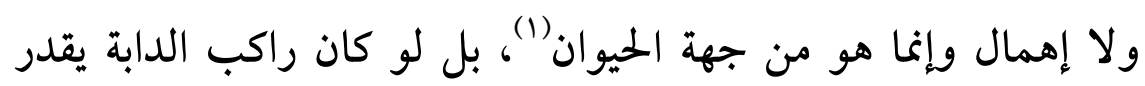

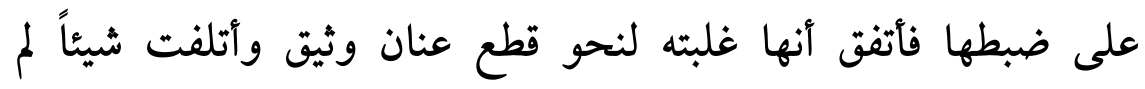
يضمن (r) - (r)

ومن هذا القبيل ما لو استؤجر على حفظ دابة فانفلتت على أخرى

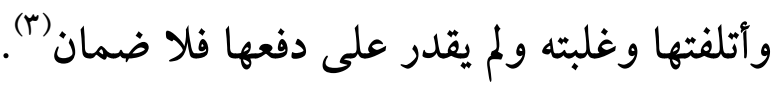

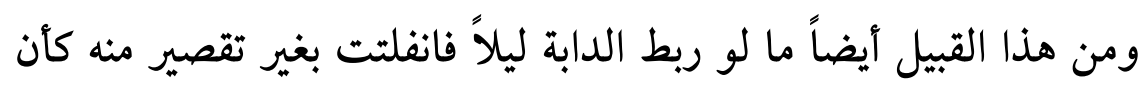

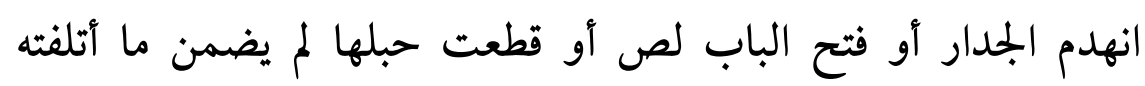

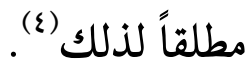
0 ـ ذكرت فيما سبق أن الدابة إذا نخسها أو ضربها شخص بدون إذن الراكب ،

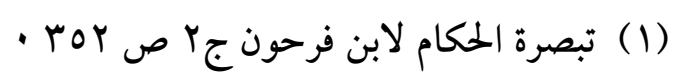

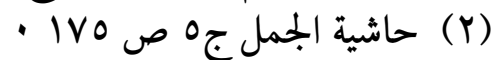

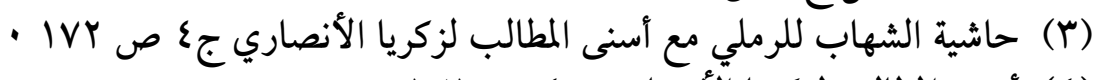

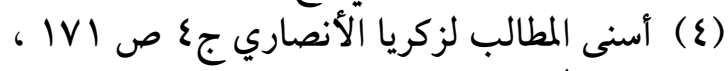

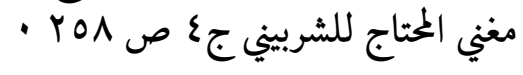


(YrA)

فإن الناخس أو الضارب يضمن ما أتلفته الدابة دون الراكب ، لأن

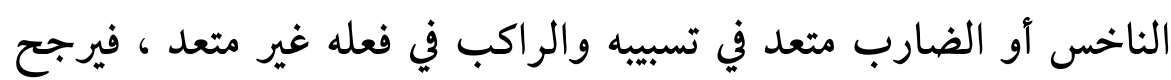

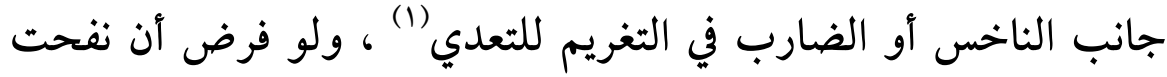

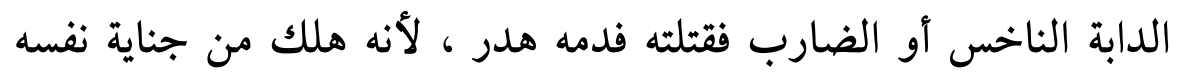

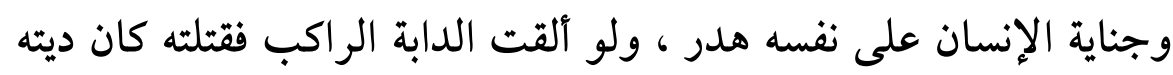

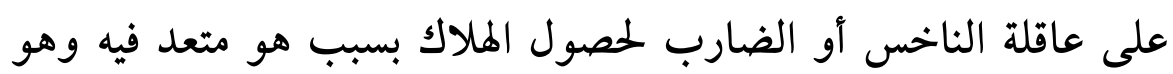

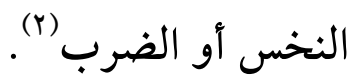

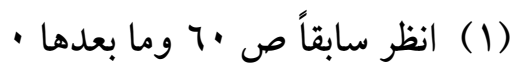

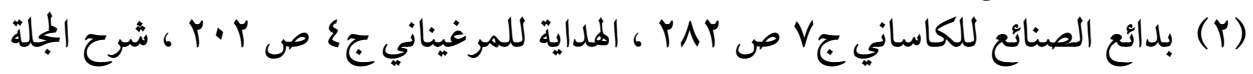

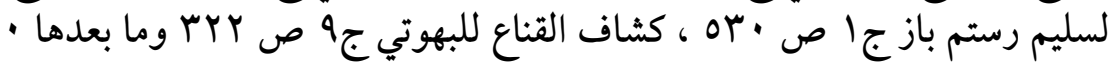




\section{المطلب الثالث}

\section{الموازنة بيز القانوز الملدني والفقه الإسلامي في وسيلة دفع المسئولية عن فعل الحيوان}

وفقاً للرأي الذي أقام مسئولية حارس الحيوان في القانون المدني على فكرة

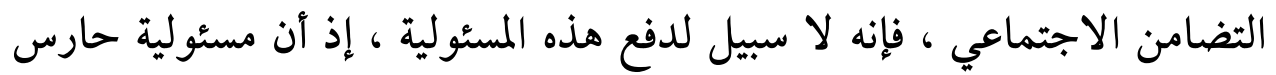

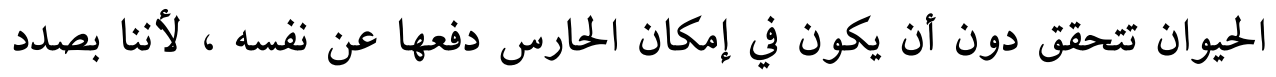
قاعدة موضوعية ، ولا ييوز مناقشة قاعدة موضوعية لاستبعاد تطبيقها . أما وفقاً للرأي الغالب في الفقه القانوني الذي أقام مسئولية حارس الحيوان

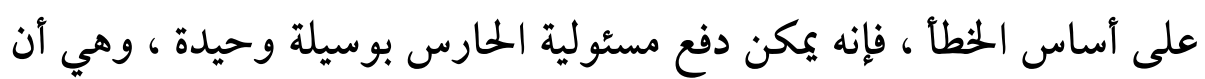

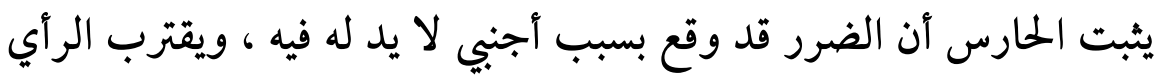

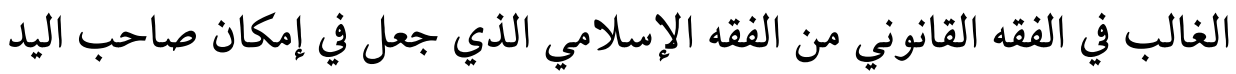

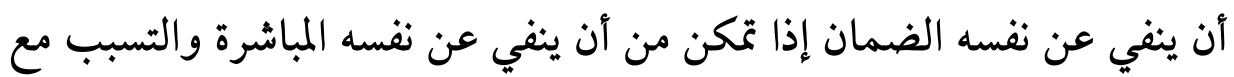

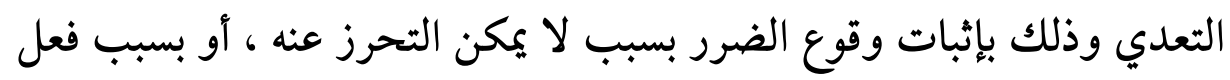

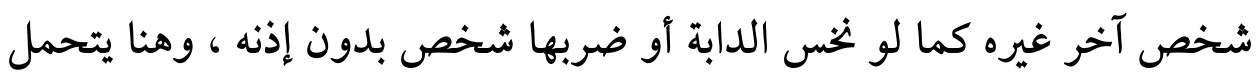

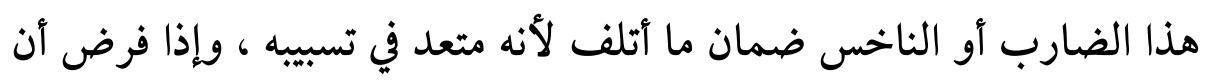

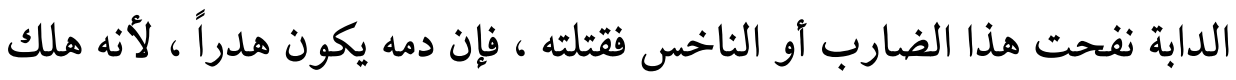

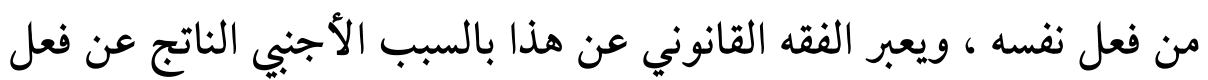
الغير أو خطأ الغير . 


\section{الخاتمة}

بعد هذا العرض الموجز لموضوع ( المسئولية عن فعل الحيوان ـ دراسة مقارنة

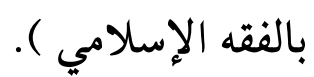

أسجل للقاريء الكريم أهم نتائج البحث وخلاصته في النقاط التالية :

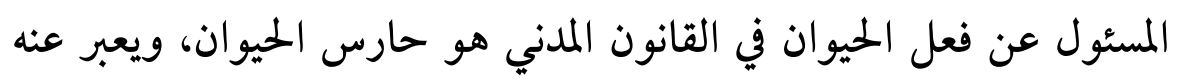

$$
\text { الفقه الإسلامي بصاحب اليد على الحيوان . }
$$

والحارس في القانون المدني هو من له السلطة الفعلية على الشيء في

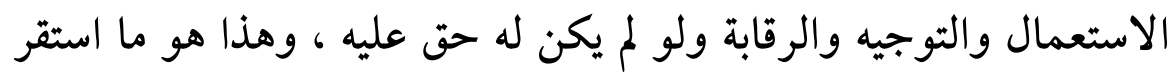

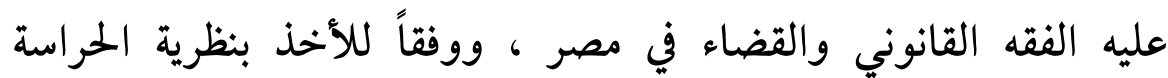

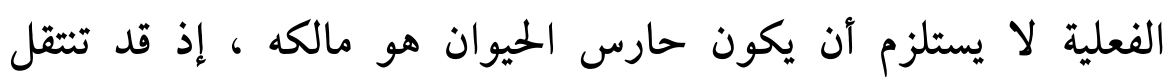

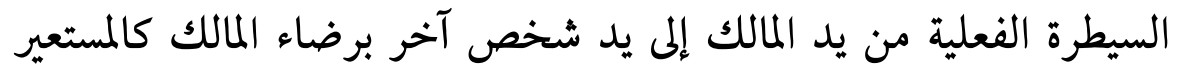

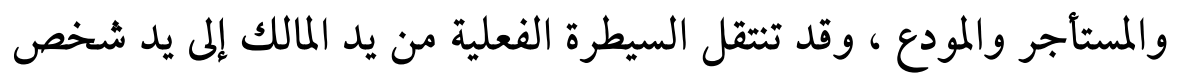

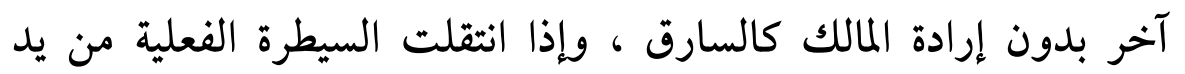

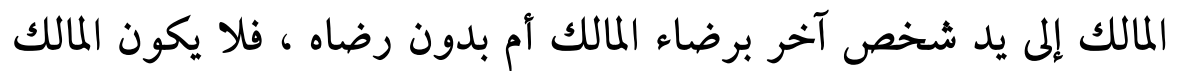

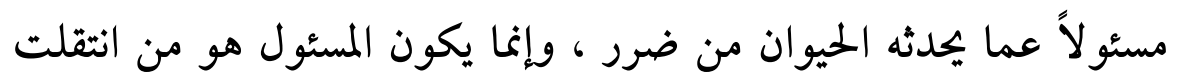

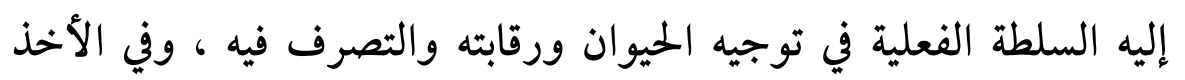

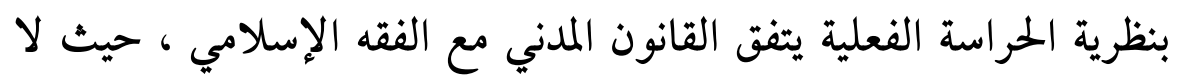

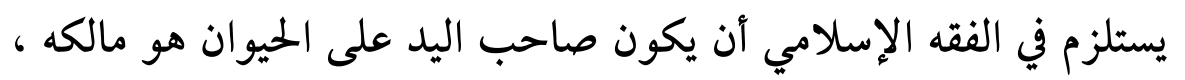

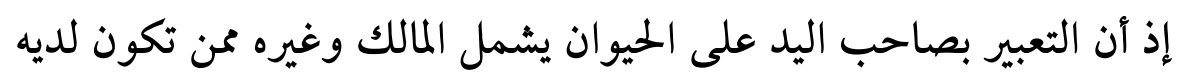




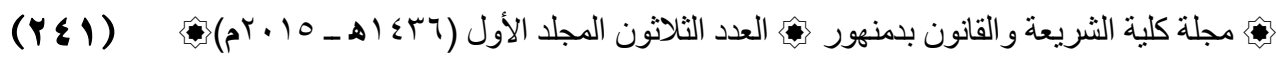

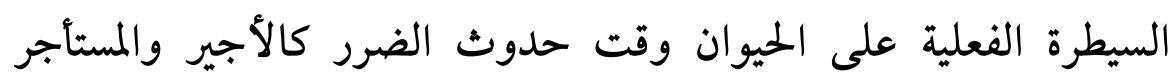

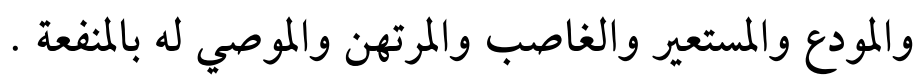
ثانيًا : يسأل الحارس في القانون المدني عن فعل الحيوان حتى لو ضل أو تسرب ،

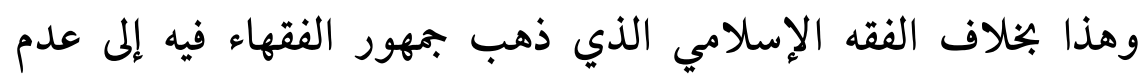

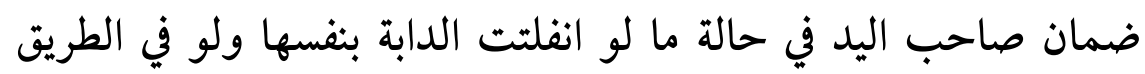
أو في ملك غير صاحبها ، ومرد ذلك إلى أن صاحب اليد لاحل لا يعتبر في هذه اله

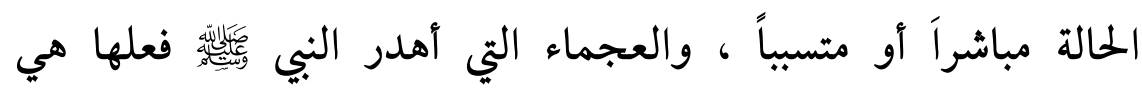
المنفلتة .

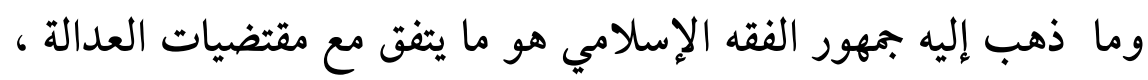

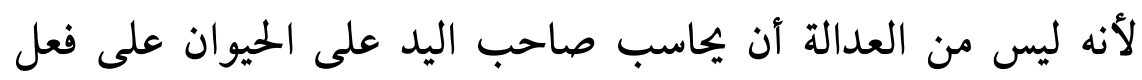
حدث من الحيوان بدون إهمال أو تقصير من جانبه. ويسأل الحارس عن فعل الحيوان حتى ولو كان صبياً ميزاً ، وهذا

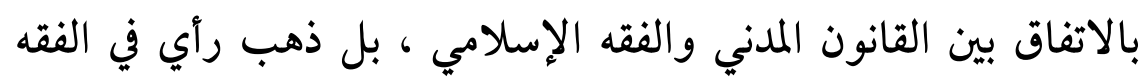

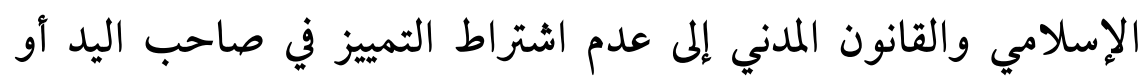

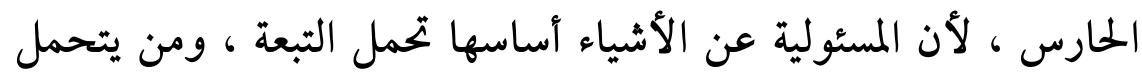

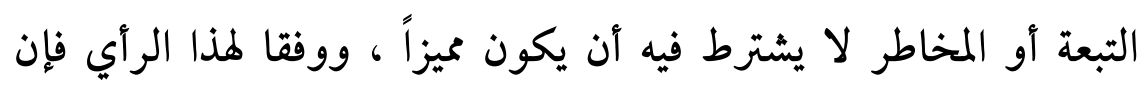

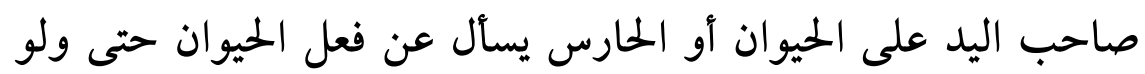

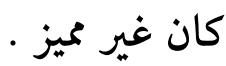

ثالثًا : يشترط أن يكون الحيوان محلاً للحراسة أو موجوداً بيد شخص حتى 
تتحقق المسئولية عن فعل الحيوان ، كما يشترط وجود فعل من الحيوان ،

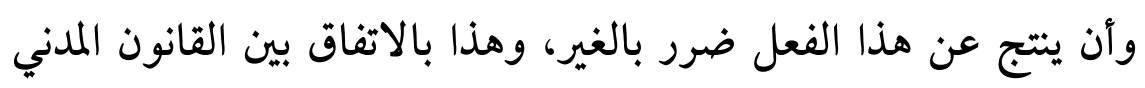
والفقه الإسلامي .

وعن شرط وجود فعل من الحيوان ، فإنه يجب أن يكون الحيوان قد أتى

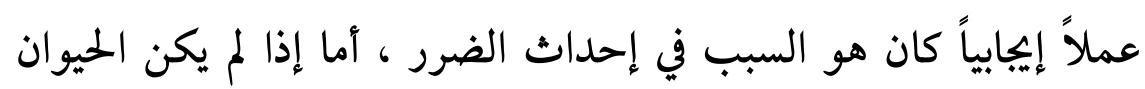

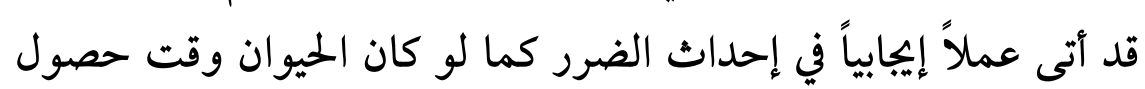

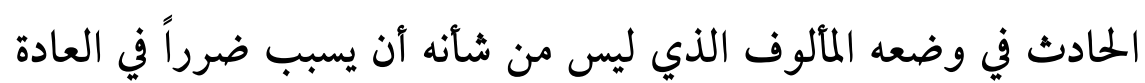

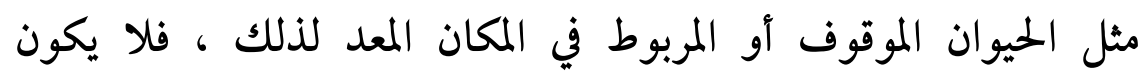

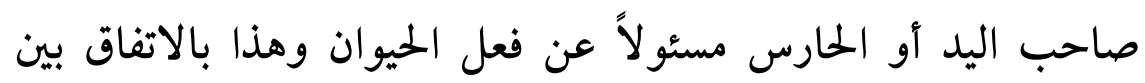

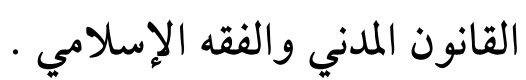
كما يتفق القانون المدني مع الفقه الإسلامي في اشتراط تحقق الضرر

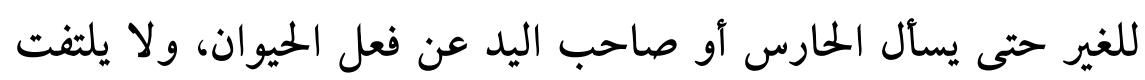

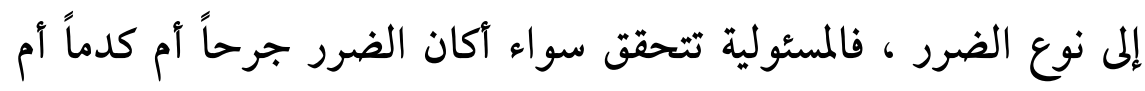
ذعراً.

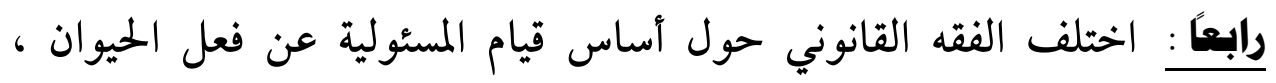

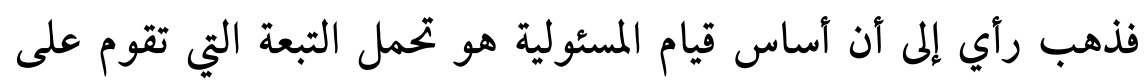

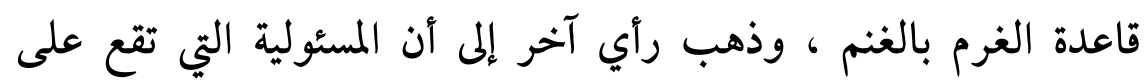

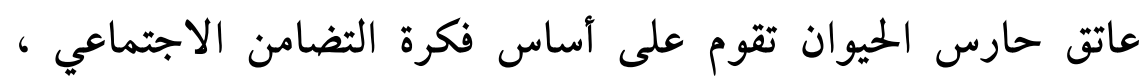

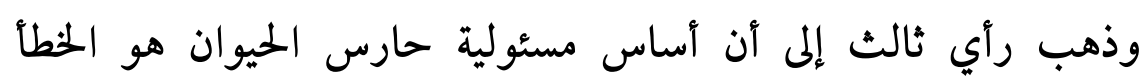

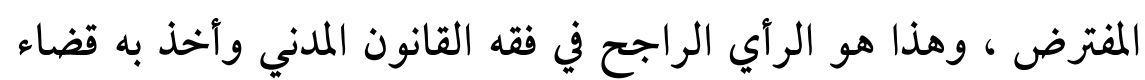




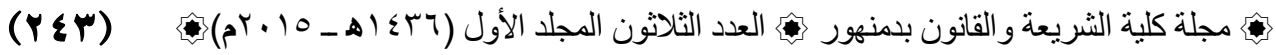

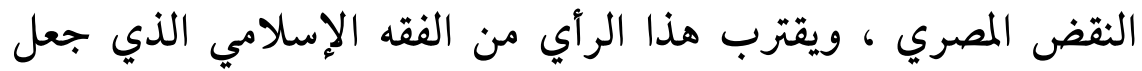

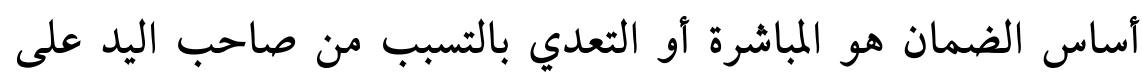

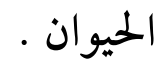

خاهسيً: لا سبيل لدفع مسئولية حارس الحيوان عند من أقام مسئولية الحارس في

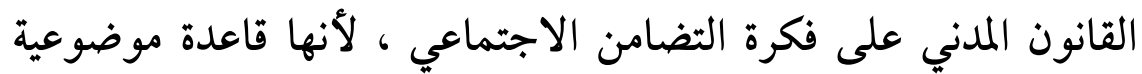

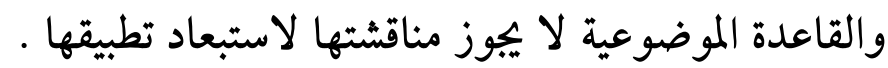
أما الرأي الغالب في الفقه القانوني الذي أقام مسئولية حارس الحيوان

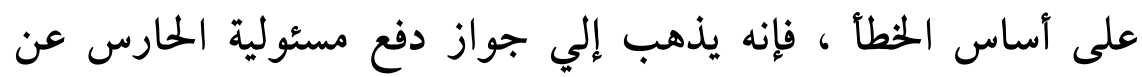

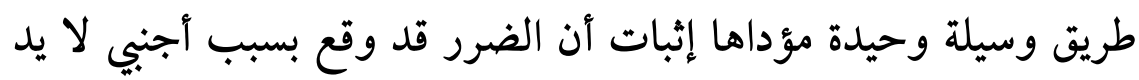

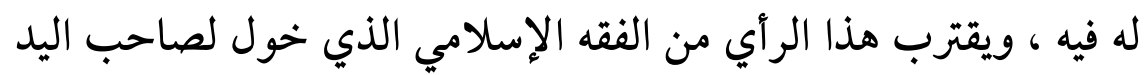

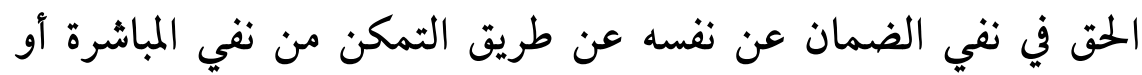

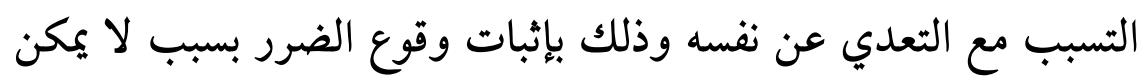

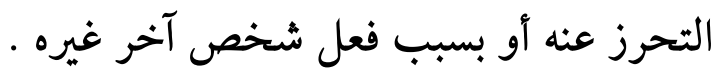




\section{مراجع البحث (1)}

أولاً : القرآن الكريم وعلوههه :

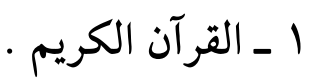

r ـ تفسير القرآن العظيم للإمام الحافظ أبي الفداء إسماعيل بن كثير القرشي

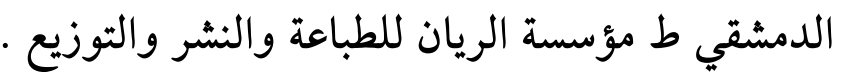

r ـ فتح القدير الجامع بين فني الرواية والدراية من علم التفسير للإمام محمد بن

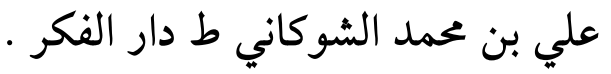

\section{ثانياً : الحديث وعلوهـه :}

1 - تلخيص الحبير في تخريج أحاديث الرافعي الكبير للإمام الحافظ

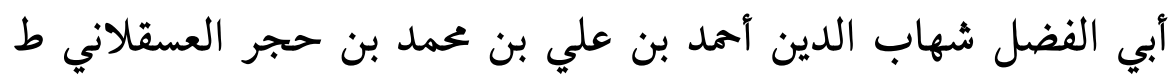

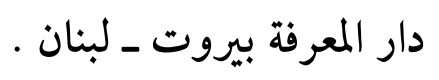

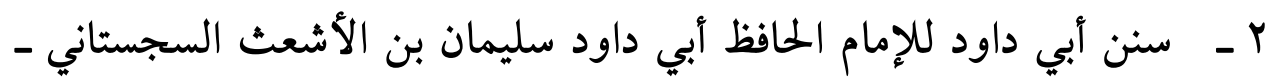

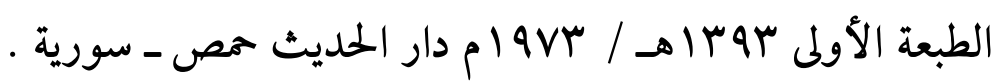

r - ـ سنن الدار قطني للإمام الكبير علي بن عمر الدار قطني ط عالم الكتب بيروت .

ع - صحيح البخاري للإمام الحافظ أبي عبد الله محمد بن إسماعيل البخاري

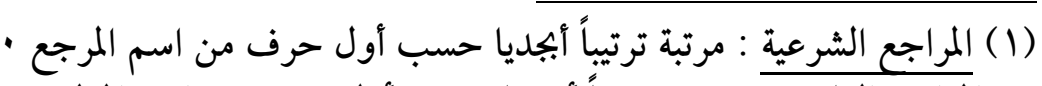

$$
\begin{aligned}
& \text { المراجع القانونية : مرتبة ترتيباً أبجديا حسب ألمديا حسب أول حرف مرف من اسم المؤلف . }
\end{aligned}
$$




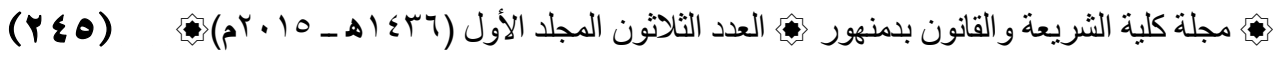
الجعفي ط شركة دار الأرقم بن أبي الأرقم للطباعة والنشر والتوزيع

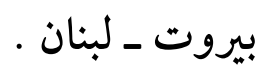

0 ـ صحيح مسلم للإمام أبي الحسين مسلم بن الحجاج القشيري النيسابوري -

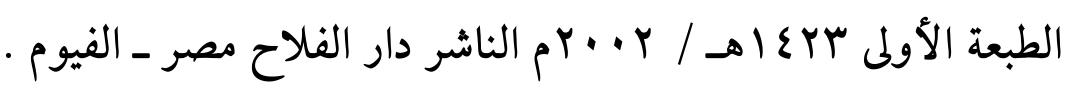

\section{ثالثًا : الفقه الحنفي :}

1 - الأشباه والنظائر للشيخ زين الدين بن إبراهيم بن محمد الشهير بابن نجيم

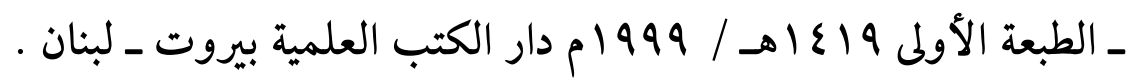

r - بدائع الصنائع في ترتيب الشرائع للإمام علاء الدين أبي بكر بن مسعود الكاساني ط دار الكتب العلمية بيروت ـ لبنان .

r - ـ تكملة البحر الرائق للعلامة المحقق الأستاذ محمد الشهير بالطوري -

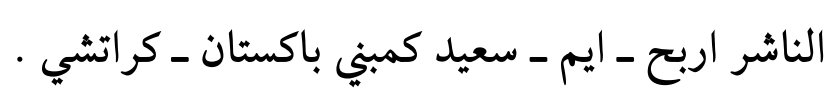

ع - حاشية المحقق سعد الله بن عيسى المفتي الشهير بسعدي جلبي وبسعدي

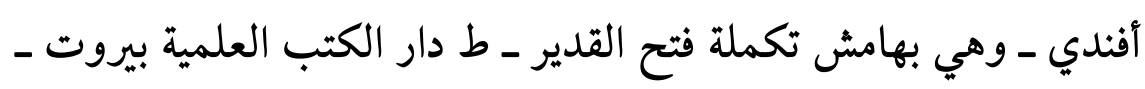

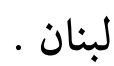

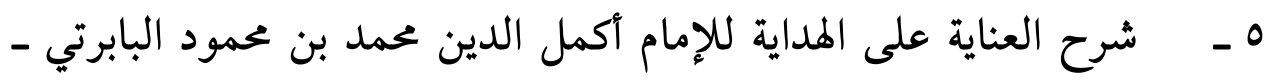

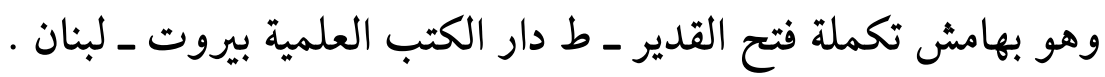
7 - الكفاية للشيخ جلال الدين الخوارزمي الكرلاني ـ مطبوعة مع تكملة

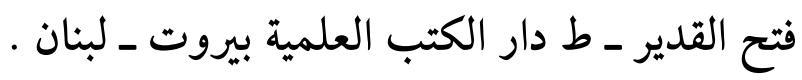

V - اللباب في شرح الكتاب للشيخ عبد الغني الغنيمي الدمشقي ط دار إحياء 


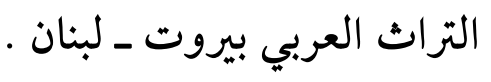

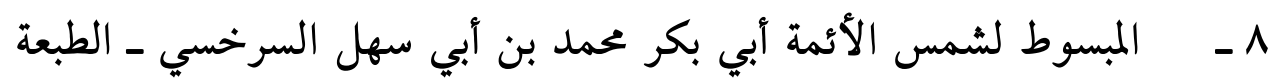

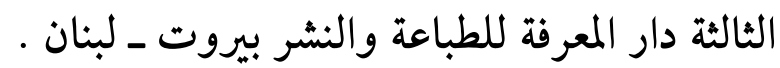
9 - بجلة الأحكام العدلية : قامت بها لجنة علمية من هيئة كبار علماء الفقه الإسلامي مع كتاب شرح المجلة لسليم رستم باز اللبناني ـ الطبعة الثالثة

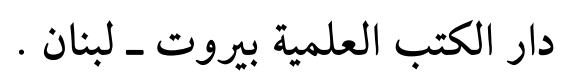

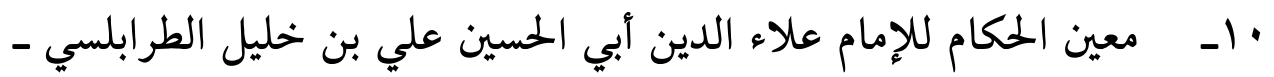

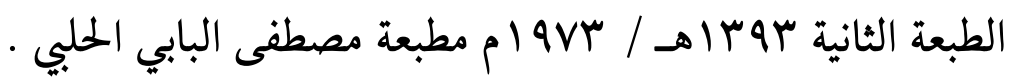

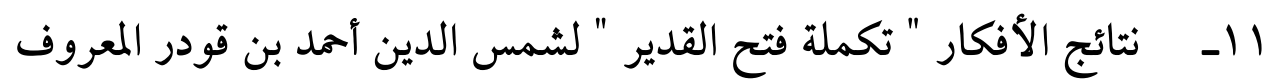
بقاضي زاده أفندي ط دار الكتب العلمية بيروت ـ لبنان ـ المدان

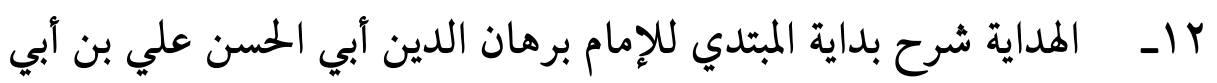

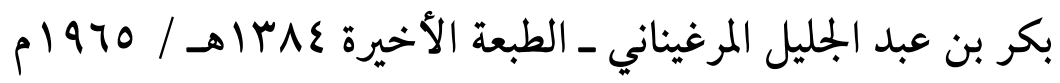
مطبعة مصطفى البابي الحلبي بمصر. رابعاً : الفقه المالكي : المئية

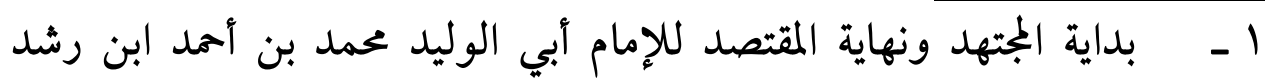

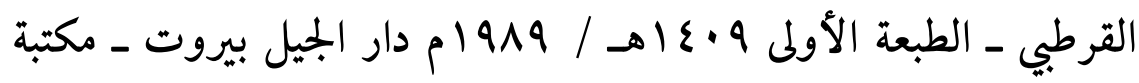
الكليات الأزهرية بالقاهرة . الأول

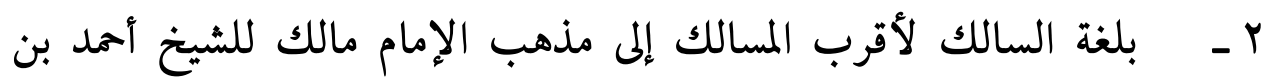

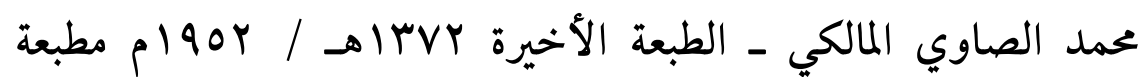
مصطفى البابي الحلبي . 


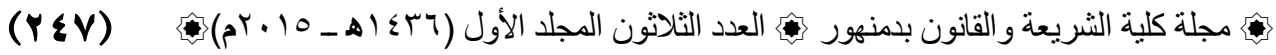

r - تبصرة الحكام في أصول الأقضية ومناهج الأحكام للقاضي برهان الدين

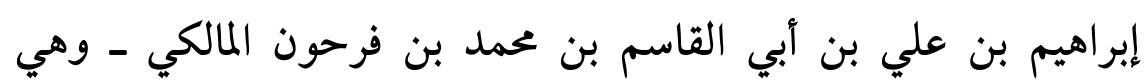

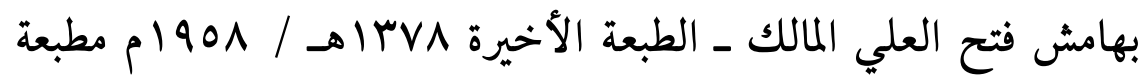
مصطفى البابي الحلبي.

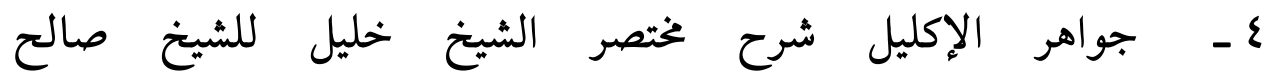

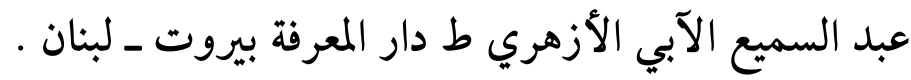

0 - حاشية الدسوقي للشيخ محمد عرفه الدسوقي - مطبوعة على الشرح

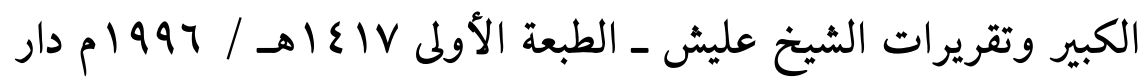

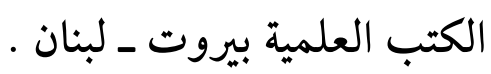

7 - - الشرح الكبير لأبي البركات أحمد بن محمد العدوي الشهير بالدردير -

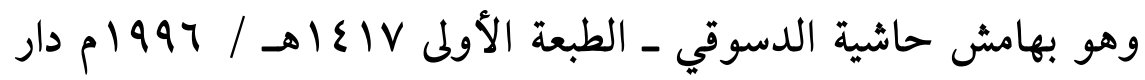

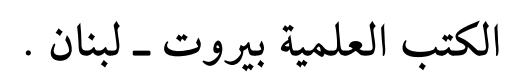

V - الفواكه الدواني على رسالة ابن أبي زيد القيرواني للشيخ أمد ابن غنيم

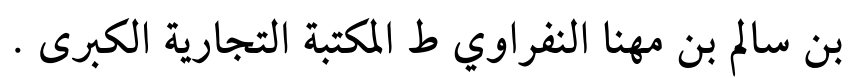
1 - فتح العلي المالك في الفتوى على مذهب الإمام مالك لأبي عبد الله

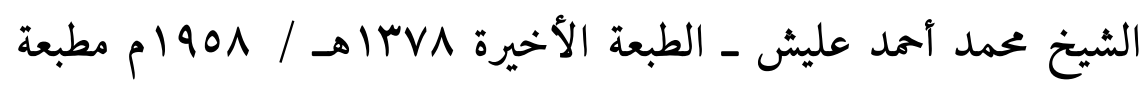
مصطفى البابي الحلبي. 9 - المدونة الكبرى للإمام مالك بن أنس الأصبحي ط دار صادر بيروت ـ

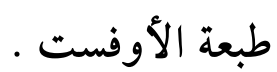


1 - أسنى المطالب شرح روض الطقالب للإمام أبي يجيي زكريا الأنصاري -

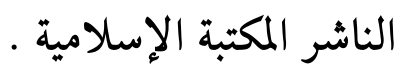

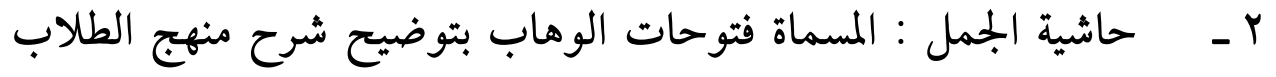

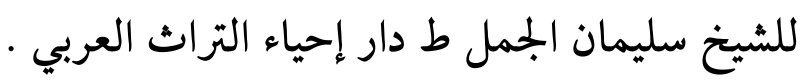

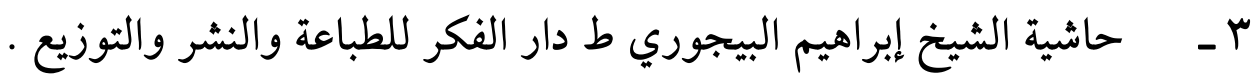
ع - حاشية الشبراملسي لأبي الضياء نور الدين علي بن علي الشبراملسي

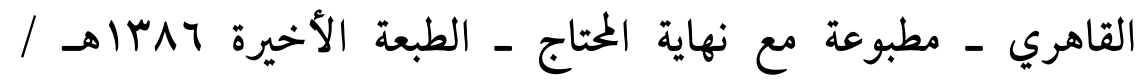
الم 9 TV

0 ـ حاشية الشرقاوي للشيخ الشرقاوي على شرح التحرير لزكريا الأنصاري

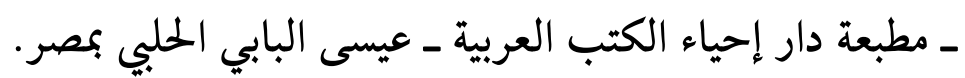
7 - - حاشية الشهاب أبي العباس أحمد الرملي الكبير الأنصاري - وهي

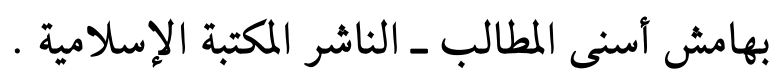
V - - Vاشيتا قليوبي وعميرة على شرح المحلى على منهاج الطالبين

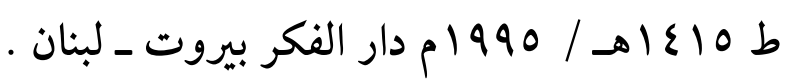
ـ - السراج الوهاج للشيخ محمد الزهري الغمراوي ط عبهام مطبعة

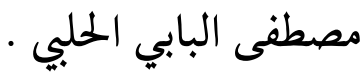
9 - شرح جلال الدين محمد بن أحمد المحلى على منهاج الطالبين - مطبوع

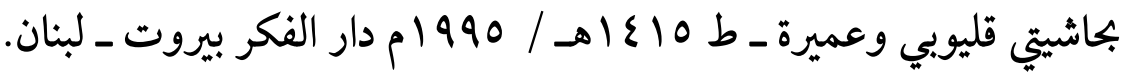




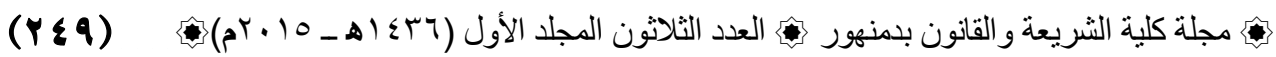

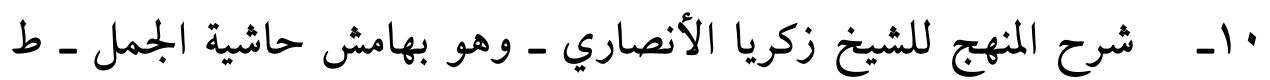

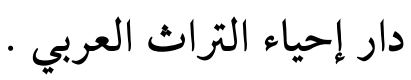
11- مغني المحتاج للشيخ محمد الخطيب الشربيني ط 10 اعـاهـ / 1990 ام دار

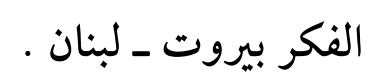

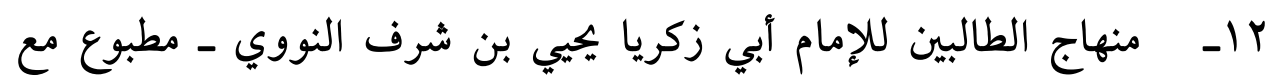

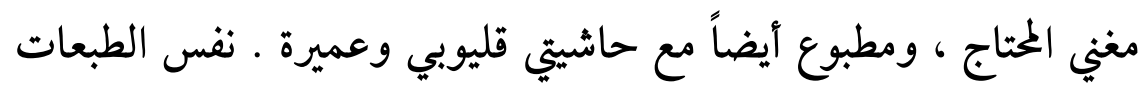

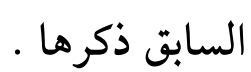

rا-ـ المهذب للإمام أبي إسحاق إبراهيم بن علي بن يوسف الفيروز آبادي

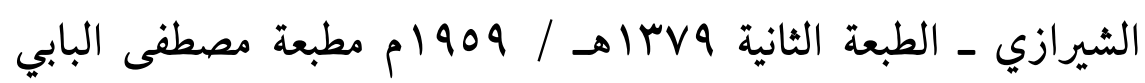
الحلبي بمصر.

ع ا- نهاية المحتاج إلى شرح المنهاج لشمس الدين محمد بن أبي العباس أحمد بن

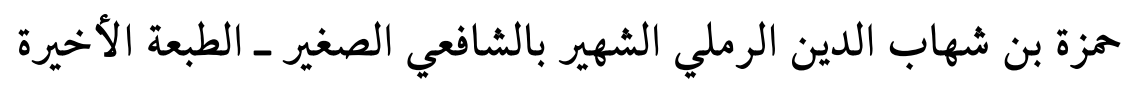

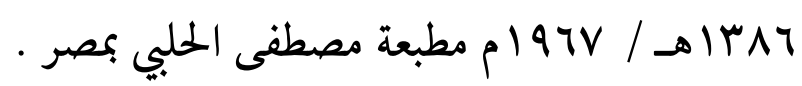

\section{سادساً : الفقه الحنبلي :}

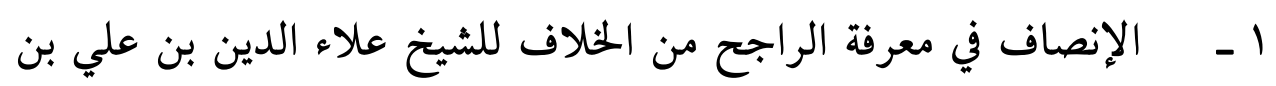

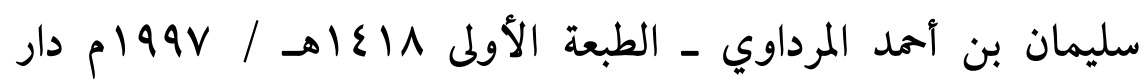

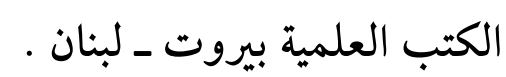

r - تصحيح الفروع - وهو مع الفروع ـ للإمام علاء الدين أبي الحسين علي

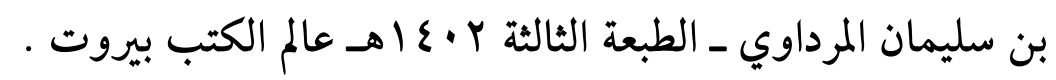


(Y०.)

r - حاشية الروض المربع لعبد الرحمن بن محمد بن قاسم العاصمي النجدي -

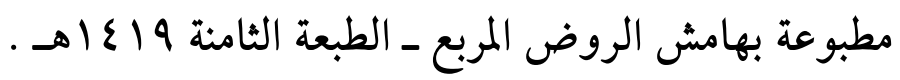

ع - الروض المربع شرح زاد المستقنع لمنصور بن يونس البهوتي ـ الطبعة

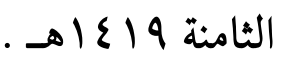

0 ـ زاد المستقنع مع الروض المربع للعلامة شرف الدين أبي النجا الحجاوي ـ

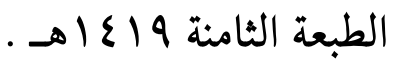

7 ـ الفروع للإمام شمس الدين أبي عبد الله محمد بن مفلح المقدسي ـ الطبعة

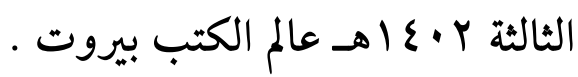

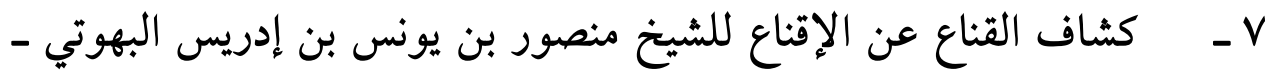

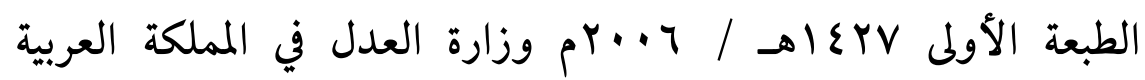

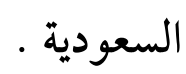

1 - المبدع شرح المقنع لأبي إسحاق برهان الدين إبراهيم بن محمد ابن عبد

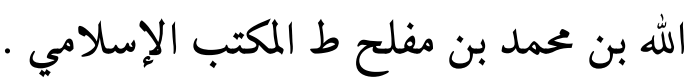

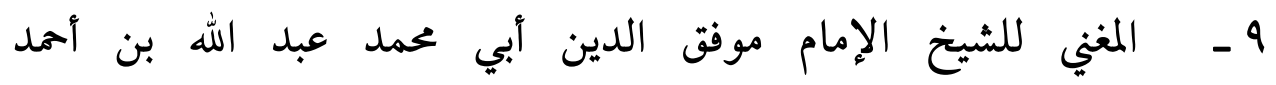

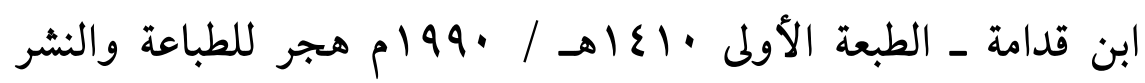
والتوزيع بالقاهرة .

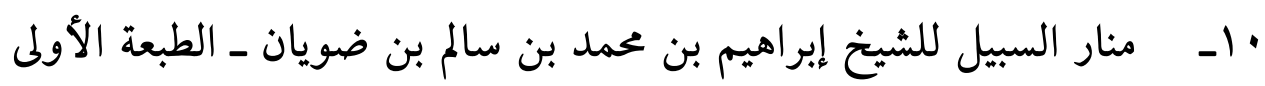

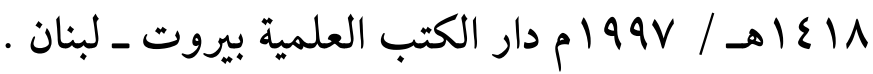




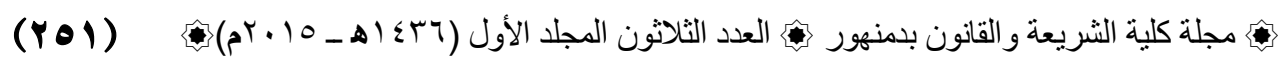

\section{سابهًا : الفقه الظاهري :}

1 - المحلى لأبي محمد علي بن أمد بن سعيد بن حزم ط دار الجيل بيروت ،

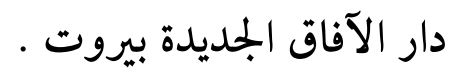

\section{ثاهنًا : المعاجم وكتب اللغة :}

1 - الصحاح تاج اللغة وصحاح العربية لإسماعيل بن مماد الجوهري -

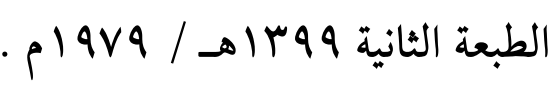

r - لسان العرب للإمام أبي الفضل جمال الدين محمد بن مكرم الأنصاري

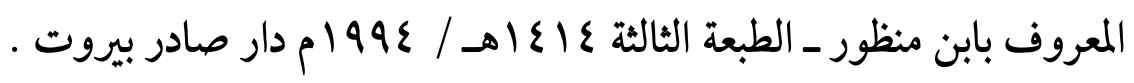
r - بختار الصحاح للإمام محمد بن أبي بكر بن عبد القادر الرازي ـ الطبعة

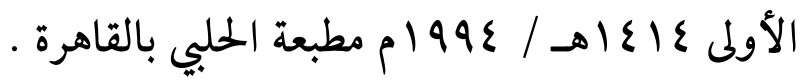

\section{تاسعًا : المراجع الهديثة في الفقه الإسلاهي :}

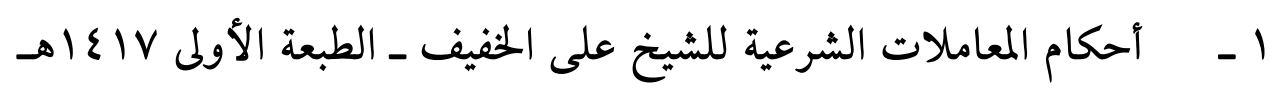

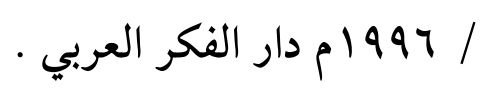

r - الفقه الإسلامي وأدلته للدكتور وهبه الزحيلي ـ الطبعة الثالثة 9 , ع اهـ

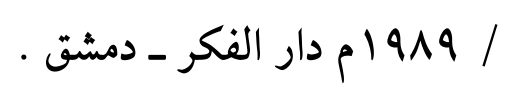

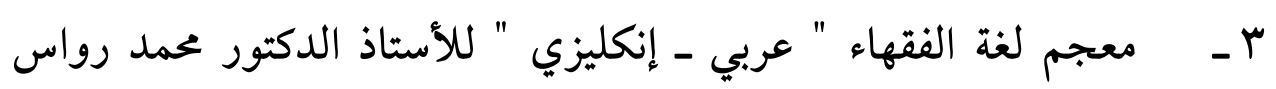

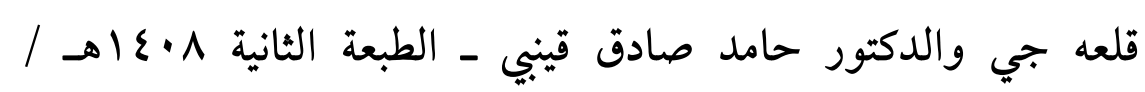

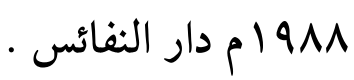
ع - الملكية ونظرية العقد للإمام محمد أبو زهرة ط دار الفكر العربي. 
(Y०Y)

المسئولية عن فعل الحيوان "دراسة مقارنة بالفقه الإسلامي"

ـ - الملكية ونظرية العقد في الشريعة الإسلامية للدكتور / أمد فراج حسين

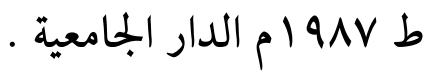

7 - - نظرية الضمان في الفقه الإسلامي للدكتور محمد فوزي فيض الله -

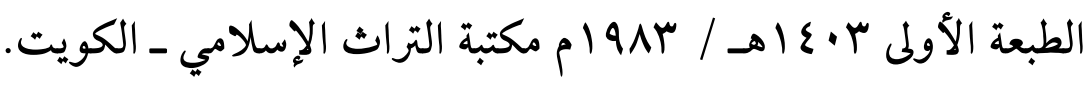

عاشراً : المراجع القانونية :

1 ـ ـ أمد سلامه ـ مذكرات في نظرية الالتزام ـ الكتاب الأول "مصادر

الالتزام " ط مكتبة عين شمس بالقاهرة .

r - / أنور سلطان ـ الموجز في مصادر الالتزام ط · 19V مطبعة محمد

هارون بوسكو ـ الإسكندرية ـ الناشر منشأة المعارف بالإسكندرية .

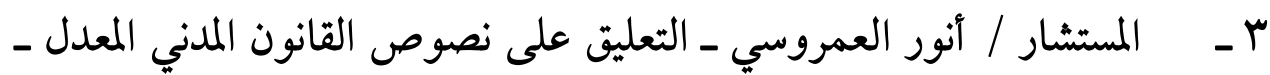

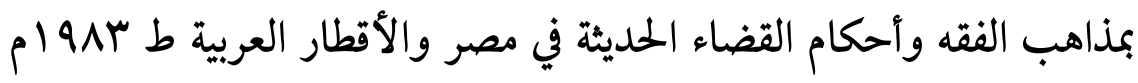

دار المطبوعات الجامعية ـ الإسكندرية .

ع - د / جلال علي العدوي ـ أصول الالتزامات " مصادر الالتزام "

ط 19VV ـ ـ الناشر منشأة المعارف بالإسكندرية .

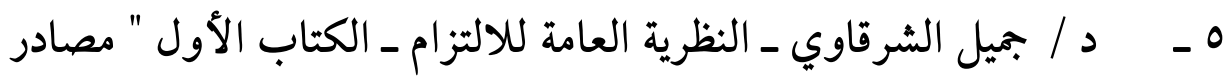

الالتزام " الطبعة الأولى ج19 ام الناشر دار النهضة العربية ـ القاهرة .

7 - حسام الدين كامل الأهواني ـ مصادر الالتزام " المصادر غير

الإرادية " ط · 199 1م مطبعة أبناء وهبه حسان ـ القاهرة . 


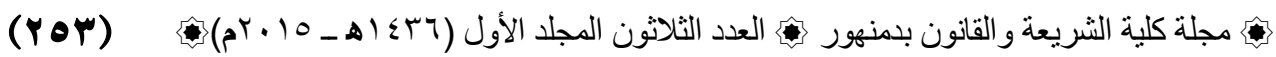

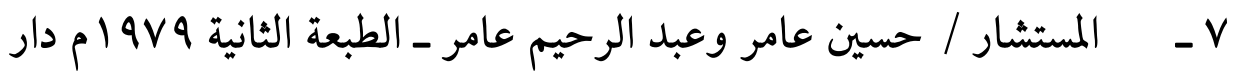

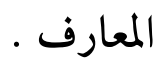

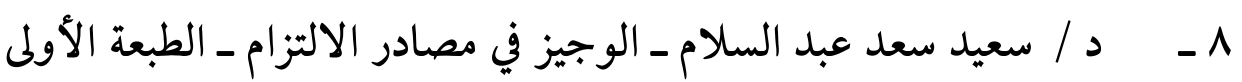
$\cdot 0^{1991}$

9 - سليمان مرقس ـ الوافي في شرح القانون المدني في الالتزامات " في

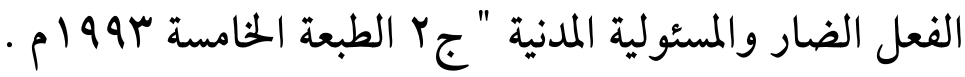

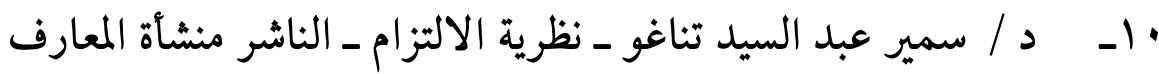

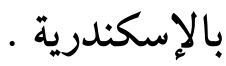

11- / عبد الرزاق أحمد السنهوري ـ الوسيط في شرح القانون المدني " مصادر الالتزام " ط ب 190 دار النشر للجامعات المصرية ـ القاهرة .

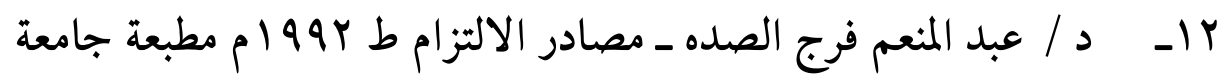

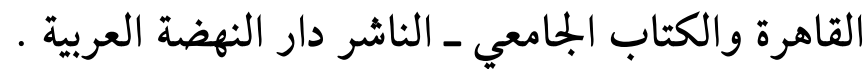

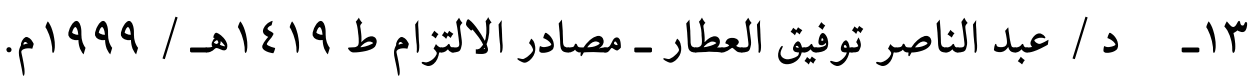
ع ا- عبد الودود يحيي ـ الموجز في النظرية العامة للالتزامات ـ القسم الأول " مصادر الإلتزام " ط ·99 19 دار النهضة العربية ـ القاهرة . 10- د / محمد إبراهيم دسوقي ـ نظرية الإلنزام ط ب999 ام . 17- د / محمد شريف أحمد ـ مصادر الإلتزام في القانون المدني ـ دراسة مقارنة

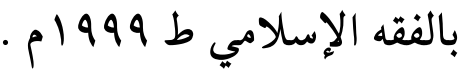




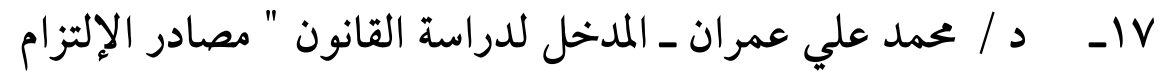

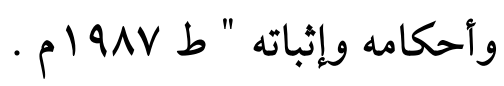

11 - د / محمد لبيب شنب ـ دروس في نظرية الالتزام " مصادر الإلتزام " - 1919 b

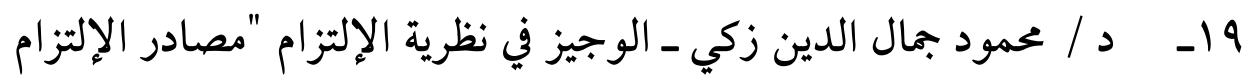
" الطبعة الثانية 9 ا ام مطبعة جامعة القاهرة والكتاب الجامعي. r. - مصطفى محمد الجمال ـ النظرية العامة للإلتزامات " مصادر الإلتزام " . 1910 b

\section{حادي عشر : المجموعات القانونية :}

1 - بجموعة الأحكام الصادرة من الهيئة العامة للمواد المدنية التي يصدرها

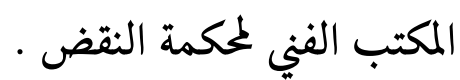
r - بجموعة الأعمال التحضيرية ـ مطبعة دار الكتاب العربي بمصر. 


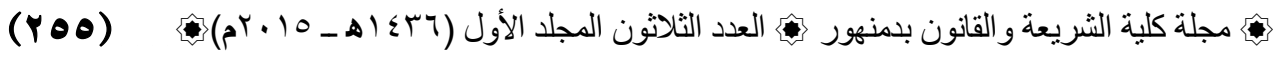

\section{فهرس الموضوعات}

\begin{tabular}{|c|c|c|}
\hline رقم & 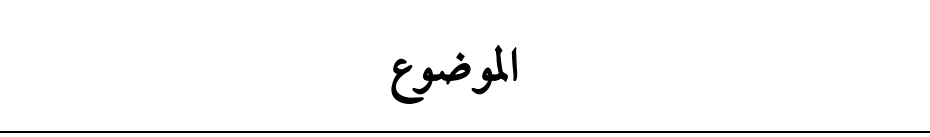 & $p$ \\
\hline 170 & المقدمة & 1 \\
\hline 171 & التمهيد & r \\
\hline IVr & المبحث الأول تحديد المسئول عن فعل الحيوان & r \\
\hline IVr & المطلب الأول تحديد المسئول عن فعل الحيوان في القانون المدني & $\varepsilon$ \\
\hline $1 \wedge 7$ & المطلب الثاني تحديد الضامن لفعل الحيوان في الفقه الإسلامي & 0 \\
\hline 194 & 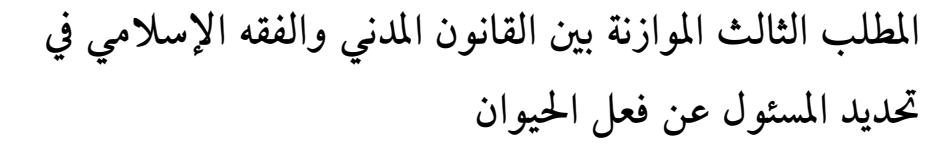 & 7 \\
\hline 190 & المبحث الثاني شروط قيام المسئولية عن فعل الحيوان & $\checkmark$ \\
\hline 190 & الملمني الأول شروط قيام المسئولية عن فعل الحيوان في القانون & $\wedge$ \\
\hline$r \cdot r$ & المطلب الثاني شروط ضمان فعل الحيوان في الفقه الإسلامي & 9 \\
\hline Y1q & 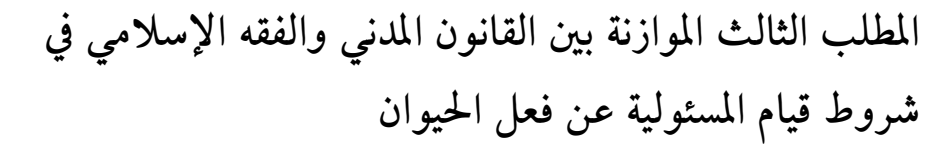 & 1. \\
\hline ryr & المبحث الثالث أساس قيام المسئولية عن فعل الحيوان & 11 \\
\hline YYY & المطنب الأول أساس قيام المسئولية عن فعل الحيوان في القانون & IY \\
\hline
\end{tabular}




\begin{tabular}{|c|c|c|}
\hline الصفحة & 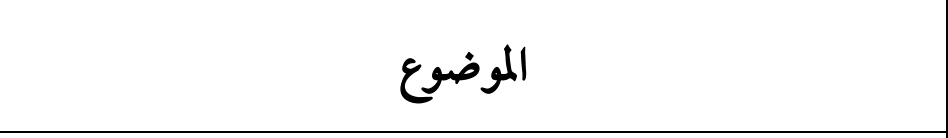 & $\rho$ \\
\hline rYA & المطلب الثاني أساس ضمان فعل الحيوان في الفقه الإسلامي & ir \\
\hline IrI & 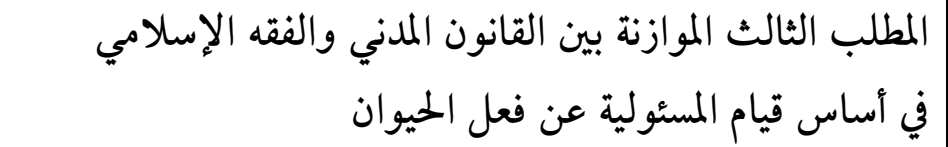 & $1 \varepsilon$ \\
\hline rmr & | المبحث الرابع وسيلة دفع المسئولية عن فعل الحيوان & 10 \\
\hline YMr & المطلب الأول وسيلة دفع المسئولية عن فعل الحيوان في & 17 \\
\hline Yro & المطلب الثاني وسيلة نفي الضمان عن فعل الحيوان في الفقه & IV \\
\hline rrq & 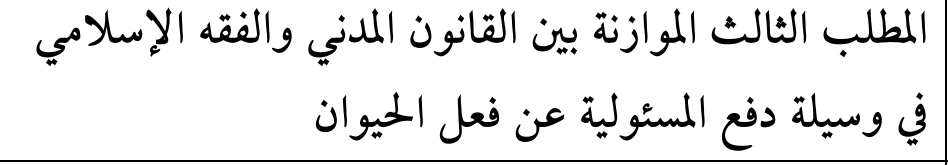 & 11 \\
\hline$r \varepsilon \cdot$ & | ت الخاتمة & 19 \\
\hline$r \varepsilon \varepsilon$ & 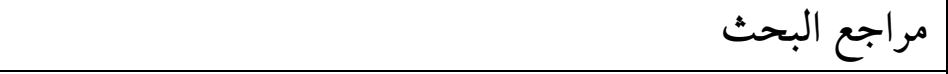 & $r \cdot$ \\
\hline roo & | فهرس الموضوعات & Yl \\
\hline
\end{tabular}

